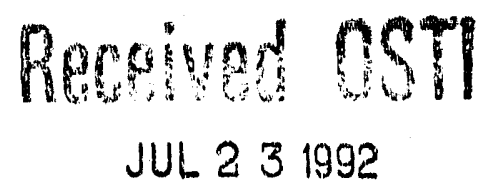

\title{
HYDROGEOLOGIC CHARACTERIZATION OF WELLS HTH-1, UE18r, UE6e, AND HTH-3, NEVADA TEST SITE
}

\author{
by \\ Brad F. Lyles \\ W. Alan McKay \\ Jenny B. Chapman \\ Scott W. Tyler
}

June 1991

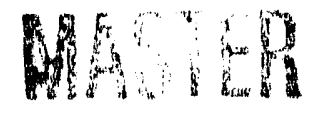


This report was prepared as an account of work sponsored by the United States Government. Neither the United States nor the United States Department of Energy, nor any of their employees, makes any warranty, express or implied, or assumes any legal liability or responsibility for the accuracy, completeness on usefulness of any information, apparatus, product or process disclosed, or represents that its use would not infringe privately owned rights. Reference herein to any specific commercial project, procest, or service by trade name, mark, manufacturer, or otherwise, does not necessarily constitute or imply its endorsement, recommendation, or favoring by the United States Government or any agency thereof. The views and opinions of authors expressed herein do not necessarily state or reflect those of the United States Government or any agency thereof.

This report has been reproduced directly from the best available copy.

Available to DOE and DOE contractors from the Office of $\$$ sientific and Technical Information, P.O. Box 62, Oak Ridge, TN 37831; prices available from (615) 576-8401.

Available to the public from the National Technical Information Service, U.S. Department of Commerce, 5285 Port Royal Rd., Springfield, VA 22161. 


\title{
HYDROGEOLOGIC CHARACTERIZATION OF WELLS HTH-1, UE18r, UE6e, AND HTH-3, NEVADA TEST SITE
}

\author{
by \\ Brad F. Lyles ${ }^{1}$ \\ W. Alan McKay ${ }^{2}$ \\ Jenny B. Chapman ${ }^{1}$ \\ Scott W. Tyler ${ }^{3}$ \\ Water Resources Center \\ Desert Research Institute \\ University and Community College System of Nevada \\ Las Vegas/Reno, Nevada
}

Publication No. 45087

prepared for

Nevada Field Office

U.S. Department of Energy

Las Vegas, Nevada

June 1991

1 Assistant Research Hydrogeologist

2 Staff Hydrogeologist

${ }^{3}$ Assistant Research Professor

The work upon which this report is based was supported by the U.S. Department of Energy under Contract \#DE-AC08-90NV10845. 


\section{CONTENTS}

PURPOSE

PHASE I TESTING PROCEDURES 2

WELL: HTH-1 4

General Background 4

Construction Details $\quad 4$

Role in Well Validation Program 4

Recent Activities at HTH-1 (1986-1990) 6

Conclusions $\quad 10$

Recommendations $\quad 12$

WELL: UE18r $\quad 12$

General Background $\quad 12$

Construction Details $\quad 12$

Role in Well Validation Program 14

Recent Activities at UE18r (1988-1990)

$\begin{array}{ll}\text { Conclusions } & 17\end{array}$

$\begin{array}{ll}\text { Recommendations } & 17\end{array}$

WELL: UE6e 17

General Background $\quad 17$

Construction Details $\quad 17$

Role in Well Validation Program 19

Recent Activities at UE6e (1990) 19

Conclusions 20

Recommendations 20

WELL: HTH-3 20

General Background 20

Construction Details $\quad 21$

Hydrogeologic Setting

Recent Activities at HTH-3 (1990) 22

Conclusions $\quad 24$

Recommendations $\quad 25$

PHASE II TESTING PROCEDURES

ACKNOWLEDGEMENTS 28

REFERENCES 29

APPENDICES

A. Hole Hisıry Data for Well HTH-1 (Fenix and Scisson, Nevada)

B. Nevada Test Site Deep Sampling Well HTH-1 (Workplan, Todd Miheve, DRI) 38

C. Hole History Data for Well UE18r (Fenix and Scisson, Nevada) 41

D. Hole History Data UE6e (Fenix and Scisson, Nevada) 54

E. Hole History Data HTH-3 (Fenix and Scisson, Nevada) 68 


\section{FIGURES}

1. General Location Map of Wells Discussed in this Report. 3

2. Generalized Schematic of Well HTH-1.

3. Preliminary Summary of Thermal Flowmeter Results for Well HTH-1. 8

4. Variations in Temperature, EC, Tritium, Calcium, and Sulfate Versus Depth for Well HTH-1. 9

5. Generalized Schematic of Well UE18r. 13

6. Preliminary Summary of Thermal Flowmeter Resuits for Well UE18r. 16

7. Generalized Schematic of Well UE6e. 18

8. Generalized Schematic of Well HTH-3. 21

9. Generalized Potentiometric Surface Map of Carbonate Açuifer Near Well HTH-3.

\section{TABLES}

1. Chemical Analyses for Well HTH-1. 11

2. Chemical Analysis for Well UE18r. 14

3. Chemical Analysis for HTH-3. 24

C-1. List of Available Electric Well Logs for Well UE18r (Appendix C). 48

E-1. Cored Intervals at HTH-3 and Recovery (Appendix E). 73 


\section{PURPOSE}

Monitoring for the migration of contaminants in groundwater or for the proper design of nuclear test emplacement holes at the Nevada Test Site (NTS) requires proper placement and completion of monitoring wells. This is only possible if the hydrogeologic system is understood in a regional and local context, necessitating data from existing wells and boreholes. Though the NTS Groundwater Characterization Project will be drilling wells, their great expense limits the number of new wells. However, there are many existing boreholes and wells on the NTS which have not been completely evaluated hydrologically. Some of these are incorporated in the LongTerm Hydrologic Monitoring Program (LTHMP) of the U.S. Environmental Protection Agency (EPA), others are related to the testing programs. In all cases, additional site investigation is necessary to properly interpret the hydrogeologic data from these wells.

Monitoring wells on the NTS are poorly characterized with regard to aquifers penetrated, vertical hydraulic gradients, and vertical variations in water quality. One of the goals of the well validation program was to gain a thorough understanding of the parameters needed to interpret the source and fate potential hazardous and radioactive substances that may be detected in these wells in the future. One of the most critical parameters for monitoring is the knowledge of what aquifer or geologic unit is being sampled when a water sample is collected. Pumped water samples are weighted most heavily to the water quality of the most productive (highest transmissivity) aquifer penetrated by the well.

Wells which are not pumped are of even greater concern. These wells are traditionally sampled by bailing a small quantity of water from some specified depth below the water table. Bailed wells, or wells that are only slightly stressed (low volume pumps) and penetrate multiple transmissive zones, pose two problems. First, vertical hydraulic gradients may exist between the transmissive zones. Differences in hydraulic head between the transmissive zones will induce ver tical flow within the borehole. Water will move into the borehole from the highest head zone and t'ow out of the borehole in those zones where the head is lower. As a result, water bailed from scme arbitrary depth may not represent the water quality of the depth sampled, but instead may be a mixed water quality from several transmissive zones. If contamination is detected, it will be difficult to define the zone or zones from which it came. The second major difficulty in the use of bailed wells without detailed hydraulic data is the use of the static water level in characterizing hydraulic head. Vertical head variations found in the few wells tested to date suggest that the measured static water level is a composite head measurement of all the aquifers and transmissive zones penetrated by the well. 
A multi-phased approach was developed to characterize the hydrology of selected wells on the NTS. Available data from monitoring wells and other open holes on the NTS were reviewed and four wells were chosen for detailed study by Desert Research Institute (DRI) and the U.S. Geological Survey (USGS), based on their hydrogeologic setting, their relative importance as downgradient monitoring wells, and for scientific interest. Phase I testing procedures were developed based on the available data from each site. Phase II testing procedures were then developed based on the available historic data and data collected as a result of Phase I testing.

\section{PHASE I TESTING PROCEDURES}

Four wells were chosen for Phase I testing: HTH-1 (USGS Test Well \#1, TW1), UE18r, UE6e, and HTH-3 (USGS Test Well \#3, TW3). HTH-1 and UE18r are currently part of the Long-Term Hydrologic Monitoring Program, UE6e is monitored occasionally by the USGS, and $\mathrm{HTH}-3$ is visited infrequently due to its location on Air Force land with restricted access (Figure 1). The four wells were categorized based on their hydrogeologic setting; HTH-1 was theorized to be in a recharge area, downgradient from the Rainier Mesa testing area; UE18r was theorized to be in a discharge/regional flow area, downgradient from the Pahute Mesa testing area; UE6e was theorized to be in a regional flow area of Yucca Flat, and was of scientific interest dut to its close proximity to testing in Yucca Flat; and HTH-3 was theorized to be in a regional flow area of the carbonate aquifer, upgradient from potential contamination sources.

Phase I testing procedures were as follows: 1) log each of the wells for temperature, electrical conductivity (EC), and caliper; 2) measure vertical flow in the well bore with the USGS thermal flowmeter at predetermined depths based on the well completion (casing history), variations in temperature and EC, and borehole wash-out zones measured by the caliper log; and 3) collect water samples from each flow zone identified from the thermal flowmeter results.

The DRI logging equipment was used to electrically log temperature and EC for wells HTH--1, UE6e, and HTH-3, prior to the USGS caliper and thermal flowmeter logging (access limitations prohibited DRI from logging UE18r). The USGS ran caliper and thermal flowmeter logs at HTH-1, UE18r, and UE6e, but were unable to access HTH-3 due to the small diameter tubing in the well. Water samples were collected from wells $\mathrm{HTH}-1$ and HTH-3, but access limitations have prohibited DRI from collecting samples at UE18r.

Detailed descriptions of the available data and preliminary results from this study are listed in individual sections for each well. 


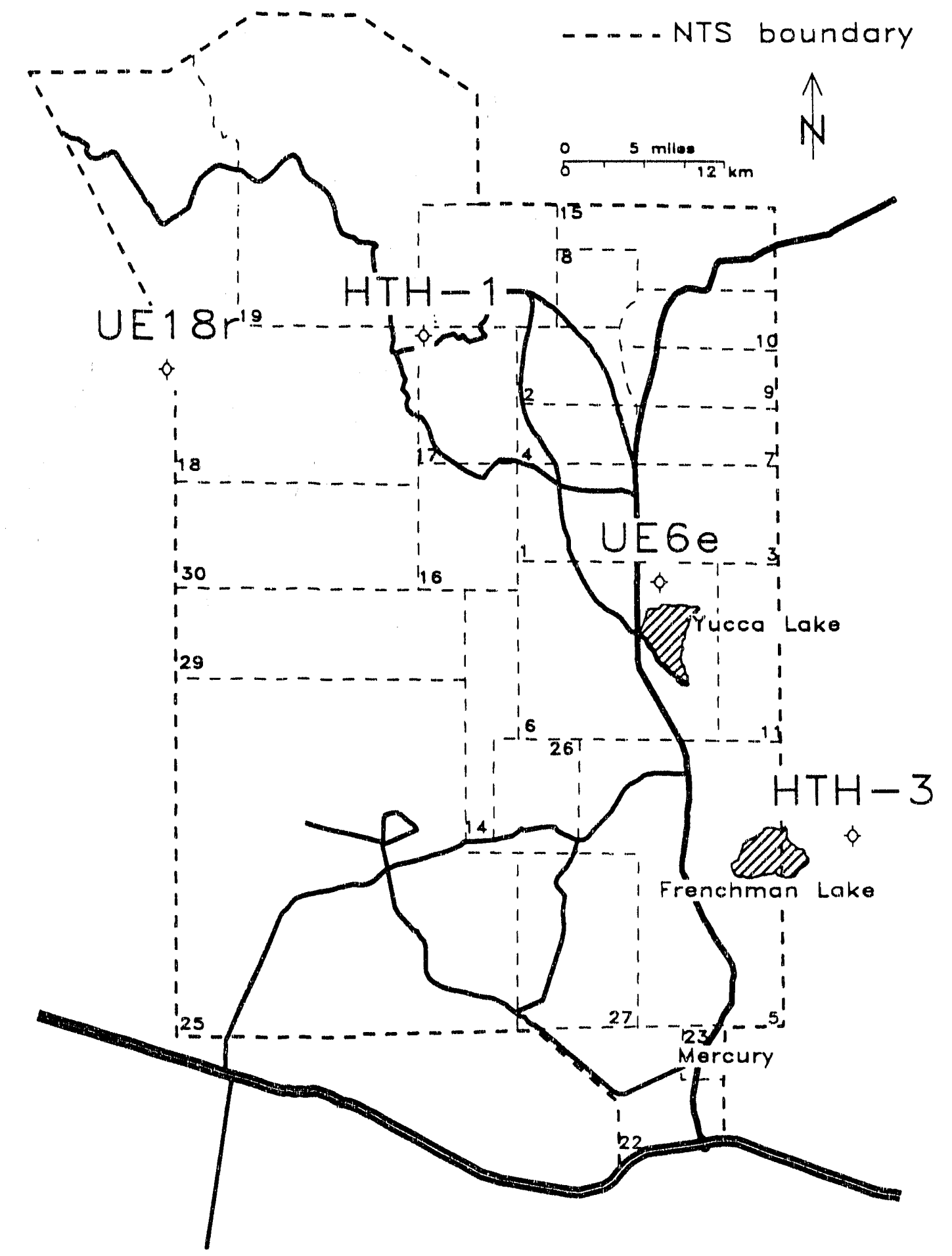

FIGURE 1. General Location Map of Wells Discussed in this Report. 


\section{WELL: HTH-1}

\section{General Background}

Hydrologic Test Hole 1 (HTH-1) was drilled in Stockade Wash, south of Rainier Mesa (N. $267,254 \mathrm{~m}$, E. $191,804 \mathrm{~m})$, at an elevation of $1876 \mathrm{~m}(6,156 \mathrm{ft}$ ) above mean sea level (Figure 1). It was one of several wells drilled to explore hydrologic conditions at the NTS in the early 1960) (Thordarson and Winograd, 1961). Conveyance hardware (pipes, valves, etc.) in the near vicinity of HTH-1 suggests that this well may, at one time, have been part of a water supply system for the Area 12 amp; however, there is nothing in the written record to confirm this and the hardware previously referred to may simply be artifacts of earlier construction activities in the area.

\section{Construction Details}

Following is a narrative summary of the drilling and construction history of HTH-1 as contained in Thordarson and Winograd (1961) and Fenix and Scisson (unpublished data, see Appendix A). Figure 2 is a schematic of the well.

HTH-1 was spudded on September 24, 1960. A 31-cm (12-inch) hole was drilled to 561 $\mathrm{m}(1,840 \mathrm{ft})$ using a cable-tool rig. A 22.9-cm (9-inch) hole was then drilled to $1,131 \mathrm{~m}(3,711$ ft) using rotary equipment. A 19-cm $\left(7 \frac{1}{2}\right.$-inch) hole was either drilled or cored another $6 \mathrm{~m}$ (20) ft) to a depth of $1,137 \mathrm{~m}(3,731 \mathrm{ft})$. Casing with a diameter of $29.3 \mathrm{~cm}$ (11 inches) was installed from the surface to $492 \mathrm{~m}(1,615 \mathrm{ft})$ and $20.3-\mathrm{cm}$ (8-inch) casing was installed from 476 to $1,131 \mathrm{~m}(1,560$ to $3,711 \mathrm{ft})$. The bottom $6 \mathrm{~m}(20 \mathrm{ft})$ were left uncased. This portion of HTH-1 construction was completed on June 10, 1961.

In July 1962, deepening work on HTH-1 began. The purpose of this additional work appears to have been primarily to obtain core, perforate discrete intervals of blank casing, and obtain hydrogeologic data throughout the hole. The original hole was deepened from 1,137 to $1,282 \mathrm{~m}(3,731$ to $4,206 \mathrm{ft})$ during this effort. Six core runs and varic us hydrologic tests were performed (Appendix A). No additional casing was installed in the deepened portion ( $145 \mathrm{~m}$ $(475 \mathrm{ft})$ ) of the hole, leaving a total of $151 \mathrm{~m}(495 \mathrm{ft})$ of uncased hole at the botton: :ITH -1 .

\section{Role in Well Validation Program}

Several factors make HTH-1 an attractive "hole of opportunity" in the well validation program. With r spect to the regional hydrology of the NTS, HTH-1 is located in a somewhat ambiguous area. Although observed decreasing head with depth measurements could indicate that the Stockade Wash area is in a zone of active recharge, Thordarson and Winograd (1961) 

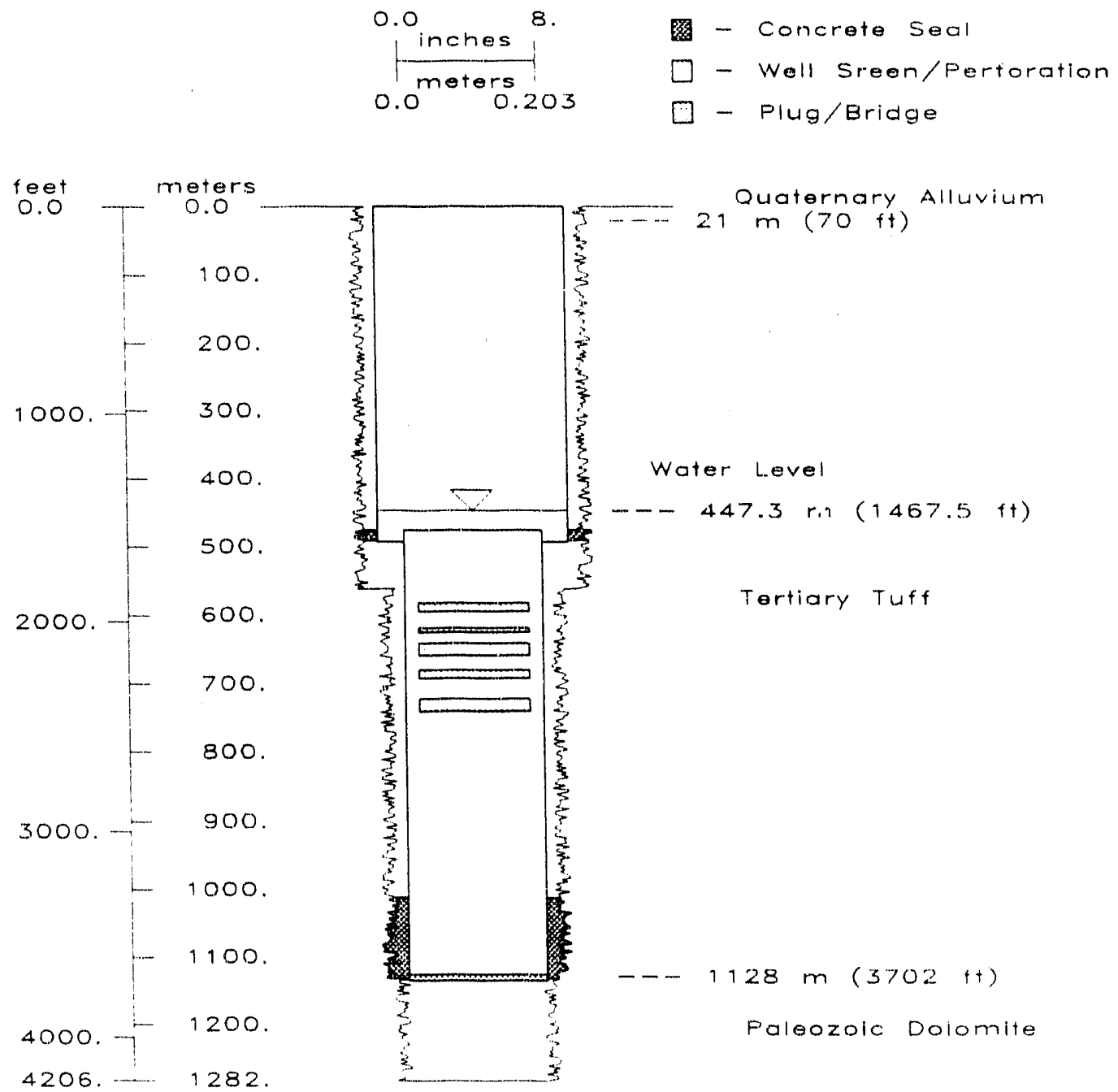

Figure 2. Generalized Schematic of Well HTH-1. 
suggest that these measurements more likely reflect a series of perched acjuifers at several depths. Previous attempts at delineating groundwater-flow systems and directions at NTS (Boughton, 1986; Feeney et al., 1987; Waddell, 1982) generally agree that there is a pronounced southerly component to groundwater flow in the Stockade Wash area. However, perusal of available water level contour maps reveals three possible direction interpretations within the southerly flow scenario: southwest toward Oasis Valley; southeast toward Yucca Valley; and due south toward Tippipah Spring and Shoshone Mountain. While detailed analysis of flow systems at the NTS is beyond the scope of this report, the preceding should provide an appreciation for the unique position occupied by HTH-1 within the regional framework of NTS hydrology. HTH-1 is also downgradient from testing activities in Rainier Mesa, and may be in a prime localion to monitor radionuclide migration from the testing area.

The stratigraphic setting at HTH-1 is also somewhat unique with respect to other available holes at NTS. Lithologic information from Thordarson and Winograd (1961) indicates that the hole penetrated $21 \mathrm{~m}(70 \mathrm{ft})$ of Quaternary alluvium, 1,107 $\mathrm{m}(3,632 \mathrm{ft})$ of Tertiary volcanic rocks, and $9 \mathrm{~m}$ (29ft) oi Paleozoic carbonate rock. Lithologic data from the previously mentioned deepening efforts are not available, but it's assumed that this additional $145 \mathrm{~m}$ (475 $\mathrm{fl}$ ) penetrated the Paleozoic rocks.

Since one of the stated goals of the well validation program is to "characterize wells with regard to lithology, aquifers penetrated, vertical hydraulic gradients, and vertical variations in water quality," hole construction is of critical importance. As indicated in the earlier section on hole construction, several intervals of casing are perforated in $\mathrm{HTH}-1$. Specifically, five different 18.3-m (60-ft) sections were gun perforated (6.6 shots per meter; 2 shots per foot) from a depth of 582 to $741 \mathrm{~m}(1,910$ to $2,430 \mathrm{ft})$. The $20.3-\mathrm{cm}$ (8-inch) tubing was gun perforated in-situ; therefore, there is no gravel pack or annular seals within the screened intervals of the well. The prospect of an additional $151 \mathrm{~m}(495 \mathrm{ft})$ of open hole in carbonate rocks was an additional attraction; however, recent logging and sampling efforts reveal some sort of obstruction at approximately $1,128 \mathrm{~m}(3,700 \mathrm{ft})$, rendering the Paleozoic section at this site inaccessible (temporarily at least) to further studies.

\section{Recent Activities at HTH-1 (1986-1990)}

In June 1986, HTH-1 was visited by a DRI logging crew with the intention of obtaining downhole electrical conductivity (EC) and temperature logs, as well as fluid samples from discrete intervals. A significant and unexpected layer of petroleum product was encountered at the top of the fluid column, temporarily disabling the logging equipment. HTH-1 was revisited by DRI in July 1987. Using an open top bailer, the oil layer was removed from the well and the 
temperature and EC logs were successfully run. The oil was analyzed and identified as pump oil and contained no PCBs. Additionally, fluid samples were collected at two depths (725 and $119 \mathrm{~m}(2,380$ and $3,670 \mathrm{ft}))$ and analyzed for tritium $\left({ }^{3} \mathrm{H}\right)$. Enriched tritium analysis yielded above-background levels of 48 and $90 \mathrm{pCi} / \mathrm{L}$, respectively. Due to the number of screened intervals, it was impossible to determine which hydrostratigraphic zones were yielding the slightly elevated tritium concentrations.

In June 1990, HTH-1 was visited by personnel from DRI and the USGS, Denver. Using the USGS logging equipment, temperature, caliper and thermal flowmeter logs were run. The caliper log confirmed an obstruction which was noted previously at a depth of approximately $1,128 \mathrm{~m}(3,700 \mathrm{ft})$ and the temperature $\log$ was consistent with earlier DRI results.

The vertical variations in above-background tritium concentrations suggest that inflow from different hydrostratigraphic zones is occurring at HTH-1. To understand the nature of this inflow, thermal flowmeter logging was performed in the borehole. The principle behind thermal flowmeter logging is conceptually simple. The thermal flowmeter is lowered to discrete depths of interest, the flowmeter's heat grid is energized, and the resulting heat pulse is monitored by thermistors above and below the heat grid. The travel time (seconds) from the heat grid excitation to the heat pulse response at the thermistor gives the fluid velocity in the well; the direction of vertical flow is then determined based on which thermistor received the signal first (if the upper thermistor receives the heat pulse first, then upward flow is indicated, alternatively if the lower thermistor receives the heat pulse first, then downward flow is indicated (Morin et al., 1988)).

Preliminary interpretation of thermal flowmeter data from $\mathrm{HTH}-1$ reveals several zones of inflow and a distinct downward component to vertical flow (Morin, personal communication, 1990) (Figure 3). Outflow may be occurring at the junction of the two different sized casings, suggesting that upward flow may be occurring; however, the dominant vertical gradient in the well appeared to be downward. Based on rough field notes, it is unclear that flow measurements were made at the bottom of the well; therefore, it may be necessary to re-log the hole to verify that water from the volcanic aquifer is mixing with water in the carbonate aquifer. The downward flow interpretation is consistent with previous studies (for example, see Feeney et al., 1987) which identify Stockade Wash as a groundwater-recharge area at the NTS.

In September 1990, discrete samples were collected from HTH-1 at seven depths following the sampling protocol outlined in Appendix B. Water samples were collected and analyzed at DRI for major cations and anions, and tritium. The significant results are shown diagrammatically alongside the well completion, EC log, and temperature log in Figure 4. The water 

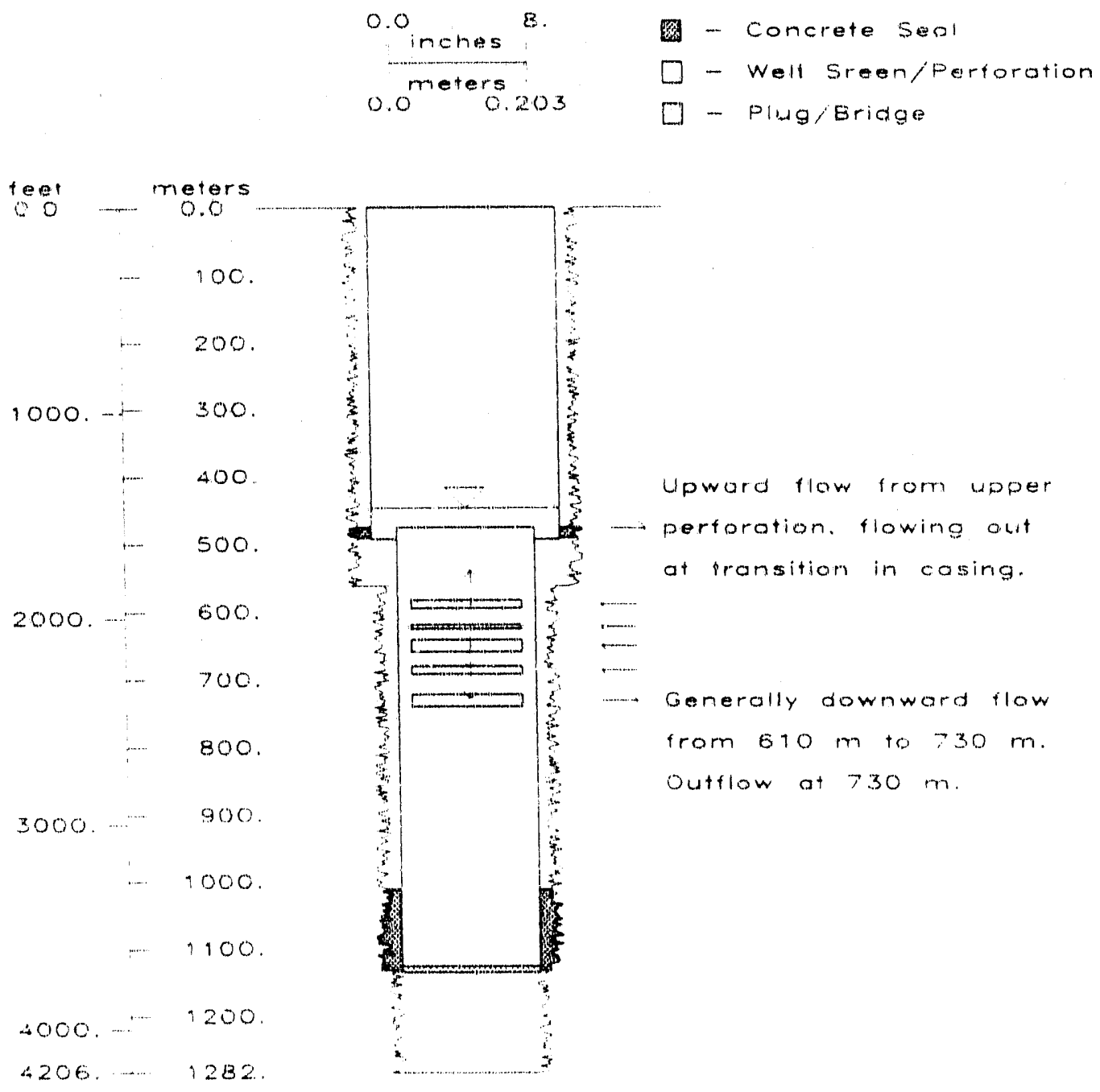

Figure 3. Preliminary Summary of Thermal Flowmeter Results for Well HTH-1. 


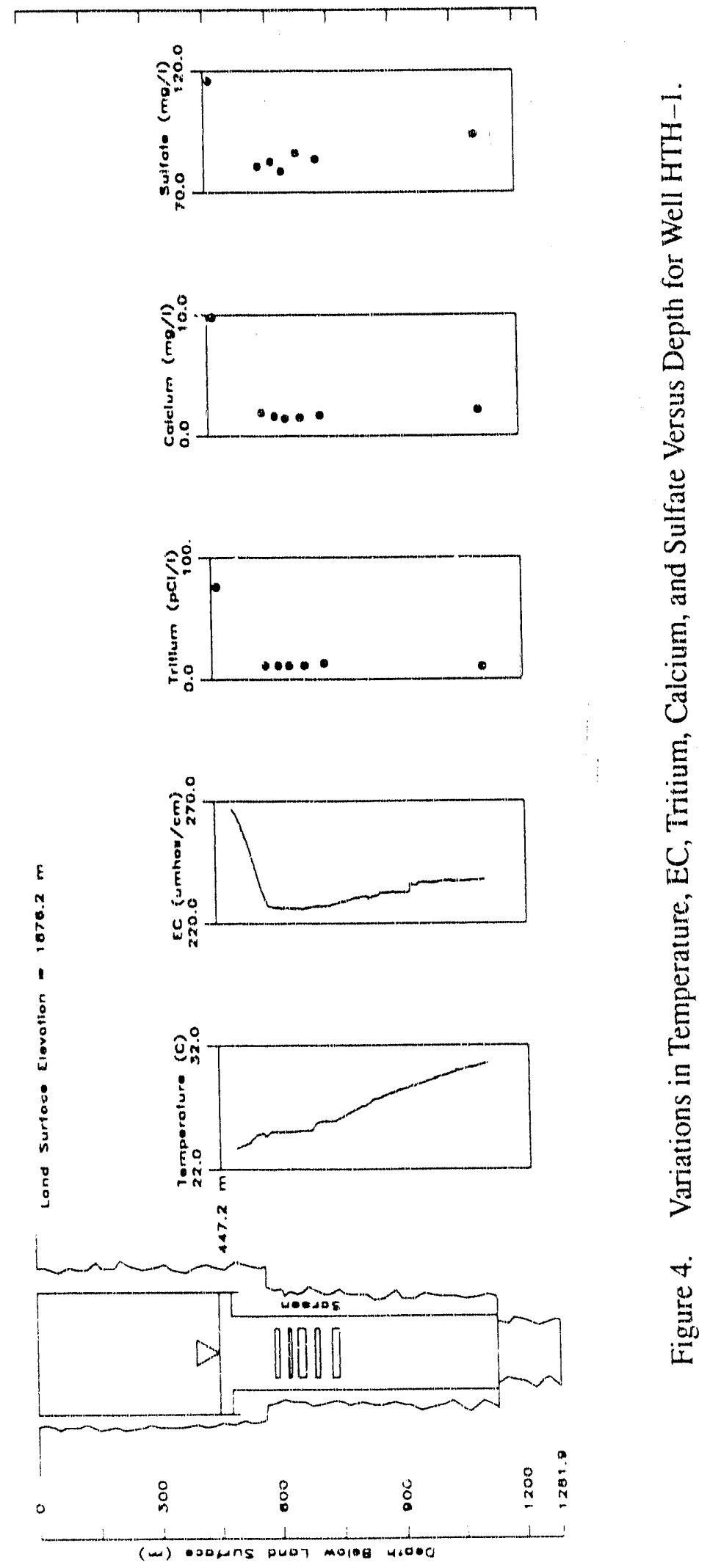


chemistry was relatively uniform along the depth of the hole, with the only significant difference observed near the change in casing diameter (Table 1). At this depth, the pH was slightly lower, the calcium concentration was approximately five times higher, and sulfate concentiation was approximately two times higher than valles below this depth. The highest tritum concentration was also observed at this depth, $76 \mathrm{pCi} / \mathrm{L}$, compared with 10 to $13 \mathrm{pCi} / \mathrm{L}$ observed below this depth. The geochemical variations may be resulting from residual oil contamination or possible groundwater mixing; further sampling may be required to fully understand the variations.

In November 1990, discrete samples were collected at $588 \mathrm{~m}(1,930 \mathrm{ft})$ with a commercial tool made by TAM International. A 250--ml samplo was collected once the tool was lowered to $588 \mathrm{~m}(1,930 \mathrm{ft}$ ) (referred to as "before" in Table 1). Packers were inflated in the well above and below the screened interval, with the sampler positioned equal distance between the packers. Several times the volume of the packed-off interval were then pumped to the zone above the upper packer. A 250-rril sample was then collected (referred to as "after" in "Table 1), the packers were deflated, and the sampler tool was retrieved from the well. Samples were contaminated with oil that apparently was used as a lubricant in the sampler. The samples were analyzed for major cations and were compared to bailed samples from the same ciepth, collected two months earlier. Both TAM samples were higher in dissolved cation concentrations than previous bailed samples. Conversations with TAM personnel revealed that the tool had been tested in a well at their facility in Texas three days prior to the test at HTH-1. The current tool design precludes complete decontamination of the tool; therefore, the samples collected by TAM were probably contaminated with residual water left in the sampler.

Although thermal flowmeter logging has helped confirm inflow zones and vertical gradients, a discrete fluid sampling technique analogous to the flowmeter method will ultimately be required to accurately assess the source of elevated tritium at $\mathrm{HTH}-1$. Toward this end, tentative plans are underway to employ a wireline packer and sampling device at HTH-1 to collect fluid samples from discrete intervals in the well.

\section{Conclusions}

Given its location relative to testing activities at Rainier Mesa, HTH-1 is a logical monitoring location for activities at the NTS. Elevated tritium levels at HTH-1 raise questions regarding the source of intlow to the Stockade Wash ground water regime. Flow system analysis by Feeney et al. (1987) suggests that in addition to being in a zone of active recharge, Stockade Wash receives significant ground water inflow from Rainier and Pahute Mesas to the north. Thermalpulse flowmeter logging confirmed several zones of inflow and downward flow at HTH-1. 


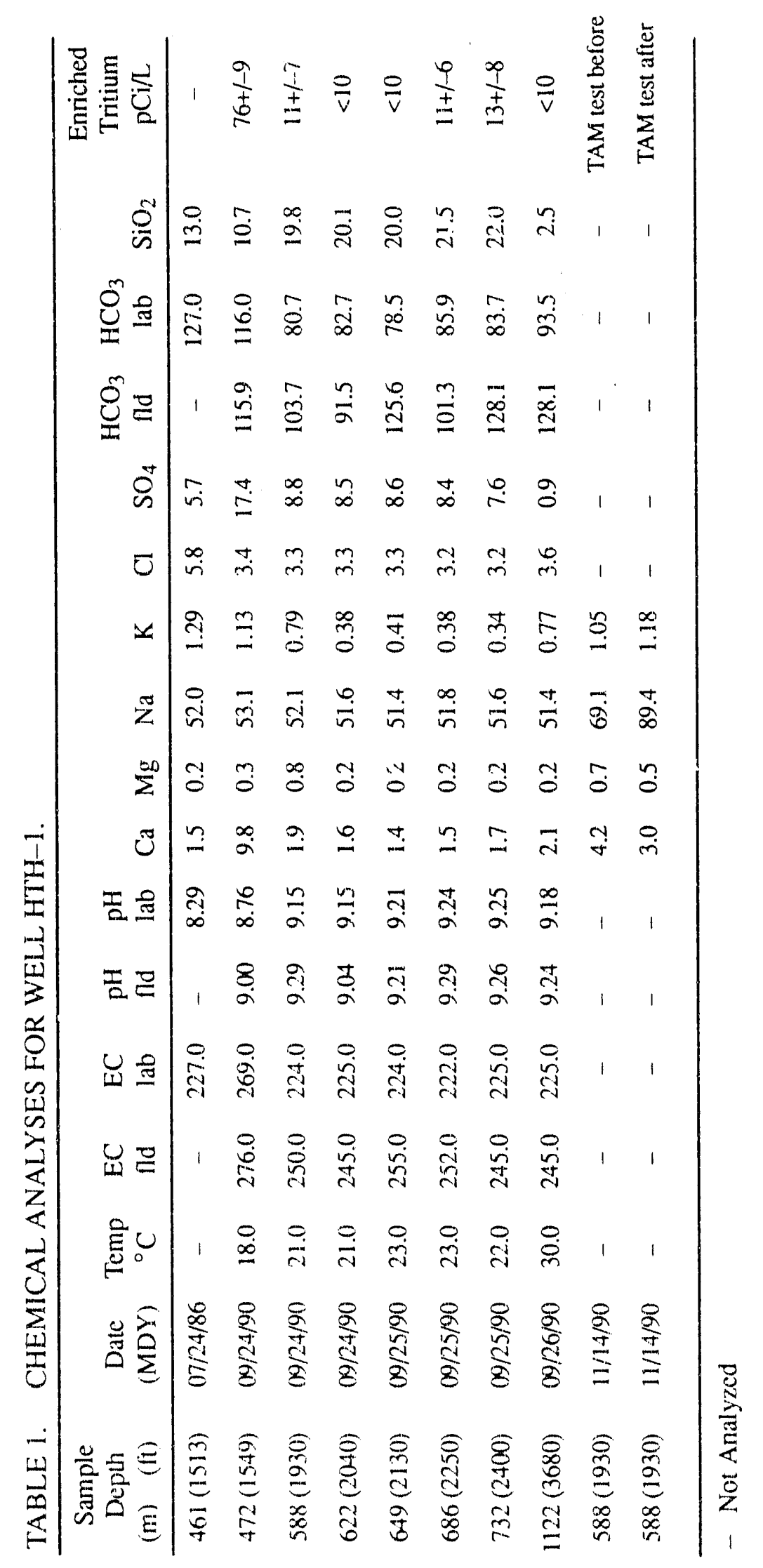


The lack of annular seals in the perforated zones add additional complexity to the interpretation of the vertical geochemical variations observed during this study. Inflow and outflow zones measured in the well can be used to interpret potential sources for the geochemical variation. However, the thermal pulse flowmeter results need to be refined prior to making any firm conclusions about geochemical sources and sinks.

\section{Recommendations}

1. Run thermal flowmeter below $741 \mathrm{~m}(2,430 \mathrm{ft})$.

2. Establish access to the carbonate aquifer for monitoring and testing.

3. Upon review of results from steps number 1 and 2, recommendations will be made addressing the recompletion of the well.

\section{WELL: UE18r}

\section{General Background}

Well UE18r was the first de:sp exploration hole in the Timber Mountain caldera and is located on the western boundary of the NTS (N. 264,584 m, E. 172,112 m), at an elevation of $1,688 \mathrm{~m}(5,538 \mathrm{ft})$ above mean sea level (Figure 1). It was drilled to investigate the structure, stratigraphy, and hydrology of the northern part of the caldera (Carr et al., 1968). An aquifer test was run in the well in 1968 for 47 hours at 15.1 liters per second (240 gpm), producing $5.8 \mathrm{~m}$ (19 ft) of drawdown. Well logs recorded during construction and testing in 1967-1968, and during a second period of testing in 1978, are listed in Appendix C.

\section{Construction Details}

The following summarizes the hole history report received from Fenix and Scisson, Nevada. Appendix C contains this document and Figure 5 illustrates a schematic of the well.

Well UE18r was spudded on November 29,1967 . A 91-cm (36-inch) hole was drilled to

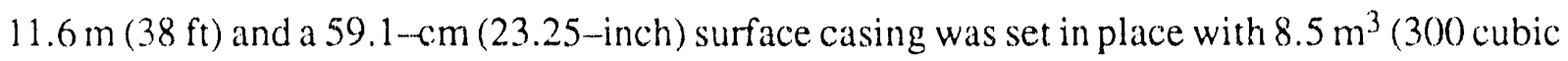
feet) of cement. A $38.1-\mathrm{cm}$ (15-inch) hole was then drilled to $497 \mathrm{~m}(1,632 \mathrm{ft})$ and a $25.5-\mathrm{cm}$ (10.05-inch) casing was set in place with $63.4 \mathrm{~m}^{3}$ (2,240 cubic feet) of cement, from the surface to a depth of $497 \mathrm{~m}(1,629 \mathrm{ft})$. A $25.1-\mathrm{cm}(9.875$-inch) hole was then drilled $1,520 \mathrm{~m}(4,988$ $\mathrm{ft})$ and a $15.6-\mathrm{cm}(6.125$-inch) hole was drilled 1,525 $\mathrm{m}(5,004 \mathrm{ft})$; both lower sections were left uncased. The well was completed on February 8, 1968. After the completion of a vibroseis survey on June 24, 1978, a Gearhart Owens wire line bridge was set at $763 \mathrm{~m}(2,505 \mathrm{ft})$ and 9.7 / (2.55 gal) of Cal-Seal were dumped in the well to form a plug (recent logging efforts show (hat this plug no longer exists). 


$$
\frac{0.0 \text { inches }}{0.0 \text { meters }} 0.255
$$

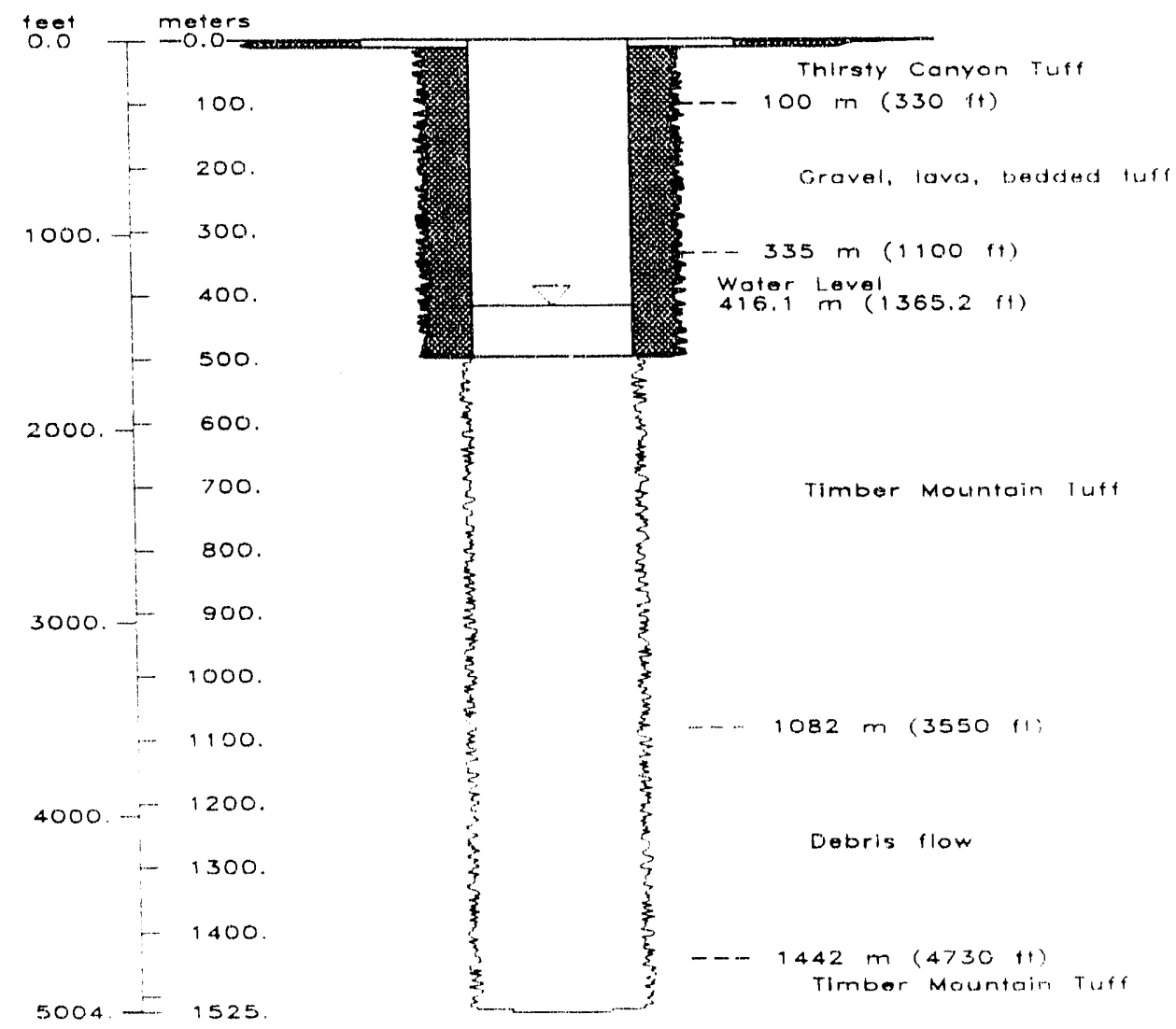

Figure 5. Generalized Schematic of Well UE18r. 


\section{Role in Well Validation Program}

Well UE18r is one of only a few wells that exist on the western boundary of the NTS; wells along this boundary are hydrologically downgradient from testing conducted on Pahute Mesa (Blankennagel and Weir, 1973). Predictions of groundwater flow and contaminant migration from Pahute Mesa will rely on hydrogeologic data from this location. Therefore, it is crucial that the hydrogeology of the site is fully understood prior to further modeing.

The major geologic units encountered consist of volcanic rocks, primarily rhyolites, tuffs, and debris flows; a detailed description of the geology was reported by Carr et al. (1968). Several hydrologic tests were conducted in 1967; three major water production zones were found above a depth of $732 \mathrm{~m}(2,400 \mathrm{ft})$, from 797 to $858 \mathrm{~m}(2,616$ to 2,816 ft) and from 1,()49 10 1,110 m $(3,442$ to 3,642 ft) (Carr et al., 1968). A tracejector survey was conducted by Blankennagel and Weir, USGS (Carr et al., 1968) which showed that 52 percent of the water pumped trom the well came from the zone 506 to $510 \mathrm{~m}(1,660$ to $1,675 \mathrm{ft}$ ) below land surface (bls); the next highest production comprised 12 percent of the flow and came from the zone $1,() 82$ to $1,085 \mathrm{~m}(3,550$ to $3,560 \mathrm{ft}$ ).

Blankennagel and Weir (1973) categorized UE18r as an intermediate transmissivity well $1.44 \times 10^{-3}$ to $5.75 \times 10^{-3} \mathrm{~m}^{2} / \mathrm{s}$ (between 10,000 and $40,000 \mathrm{gpd} / \mathrm{ft}$ ), with respect to other wells on Pahute Mesa. A 47-hour single well aquifer test was conducted under the supervision of Blankennagel and Weir in 1967 . The test was conducted at $15.1 \mathrm{l} / \mathrm{s}(240 \mathrm{gpm})$ and $5.8 \mathrm{~m}$ (19 ft) of drawdown was observed. From these data, a specific capacity of $2.7 \mathrm{lps} / \mathrm{m}(13 \mathrm{gpm} / \mathrm{ft})$ and a transmissivity of $3.3 \times 10^{-3} \mathrm{~m}^{2} / \mathrm{s}(23,000 \mathrm{gpd} / \mathrm{ft})$ were computed.

A water chemistry sample was collected from UE18r on January 29, 1968, at the end of the aquifer test. This was a composite sample representing the interval from 497 to $1,525 \mathrm{~m}$ $(1,629$ to $5,004 \mathrm{ft})$. The chemical analysis is listed in Table 2.

TABLE 2. CHEMICAL ANALYSIS FOR WELL UE $18 \mathrm{r}$ (concentration in $\mathrm{mg} / \mathrm{l}$ and EC in $\mu \mathrm{mhos} / \mathrm{cm} @ 25^{\circ} \mathrm{C}$ ).

\begin{tabular}{llccccccccccc}
\hline Dite & Source & $\mathrm{Temp}^{\circ} \mathrm{C}$ & $\mathrm{Ca}$ & $\mathrm{Mg}$ & $\mathrm{Na}$ & $\mathrm{K}$ & $\mathrm{Cl}$ & $\mathrm{SO}_{4}$ & $\mathrm{HCO}_{3}$ & $\mathrm{SiO}_{2}$ & $\mathrm{EC}$ & $\mathrm{pH}$ \\
\hline $1 / 29 / 68$ & USGS & 32.2 & 26 & 1.0 & 81 & 3.1 & 7.8 & 24 & 252 & 45 & 449 & 8.0 \\
$9 / 23 / 88$ & DRI & 27.5 & 20.6 & 0.95 & 75 & 3.32 & 6.9 & 23.4 & 225 & 52 & 416 & 8.15 \\
\hline
\end{tabular}

\section{Recent Activities at UE18r (1988-1990)}

In October 1988, UE18r was visited by DRI to log for electrical conductivity (FC) and temperature, and to collect a water sample. The well was logged to a depth of $1,189 \mathrm{~m}(3,90) \mathrm{ft})$ 
(the maximum depth capability of the DRI logging equipment), and a water chemistry sample was collected from $914 \mathrm{~m}(3,000 \mathrm{ft})$. These logs showed abrupt changes in EC and temperature at the following three zones: 427 to $506 \mathrm{~m}(1,400$ to $1,660 \mathrm{ft}) ; 579$ to $640 \mathrm{~m}(1,9() 0$ to $2,1()() \mathrm{ft})$; and 1,116 to $1,183 \mathrm{~m}(3,660$ to $3,880 \mathrm{ft})$.

In June 1990, UE18r was visited by DRI and the USGS, Denver. Using the USGS logging equipment, temperature, EC, caliper, and thermal flowmeter logs were run. Only preliminary results are available from the USGS logging; the following are observations recorded by DRI during the logging effort. The caliper log was run from approximately 411 to $1,518 \mathrm{~m}(1,35)$ to 4,980 ft) (starting from above the water table and extending to the bottom of the hole). The standing water level was encountered at $415 \mathrm{~m}(1,362 \mathrm{ft})$ bls. The caliper log showed a decrease in well-bore diameter at the water table from $25.4 \mathrm{~cm}$ (10 inches) down to approximately 12.7 $\mathrm{cm}$ ( 5 inches), suggesting that there is an obstruction in the well at the water table. Additionally, the caliper log identified four zones where the well-bore diameter increased significantly: at 579 $\mathrm{m}, 823 \mathrm{~m}, 1,097 \mathrm{~m}$, and $1,341 \mathrm{~m}(1,900 \mathrm{ft}, 2,700 \mathrm{ft}, 3,600 \mathrm{ft}$, and 4,400 ft, respectively); these zones are believed to be areas of high fracture density or nonwelded tuff, and therefore were the areas targeted or thermal flowmeter logging.

The flowmeter was run first at $421 \mathrm{~m}(1,380 \mathrm{ft})(6.7 \mathrm{~m}(22 \mathrm{ft})$ below the water table $)$ to determine if vertical flow existed in the casing. A slight upward gradient was measured inside the casing, suggesting that water is flowing out of the casing somewhere. It is possible that the obstr:ction found at the water table may be cement that squeezed into the well through an opening in the casing during pressure grouting and that the outflow previously noted is occurring into a zone of lower head through this opening. Thus, the water level measured in the well may be influenced by a fracture in the casing and subsequent outflow through this fracture. As a result, the hydraulic head represented by the current depth to water may be a composite of those zones below the casing bottom, and some upper zones in the vicinity of the casing fracture. If this is the case, a composite head of only those zones below the casing is expected to be greater than one which includes this upper zone.

Inflow zones were identified at approximately 792 and $1,341 \mathrm{~m}(2,600)$ and 4,400 $\mathrm{ft})$ and outflow zones were identified at approximately 579 and $1,097 \mathrm{~m}(1,900)$ and 3,600 ft); a stagnation zone was identified between 792 and $1,079 \mathrm{~m}(2,600$ and 3,600 ft), where vertical flow was below the detection limit of the thermal flowmeter (approximately $0.5 \mathrm{~mm} / \mathrm{sec}(0.1 \mathrm{ft} / \mathrm{min})$ ) (Figure 6). The outflow zone at $579 \mathrm{~m}(1,900 \mathrm{ft})$ was considered minor and most of the water from the 792-m $(2,600-\mathrm{ft})$ inflow zone was leaving the well at the water table $(415 \mathrm{~m}(1,362$ fi)). 


$$
\left.\left.\right|_{0.0} ^{0.0 \text { meters }}\right|_{0.255} ^{10 .} \text { - Concrete seal }
$$

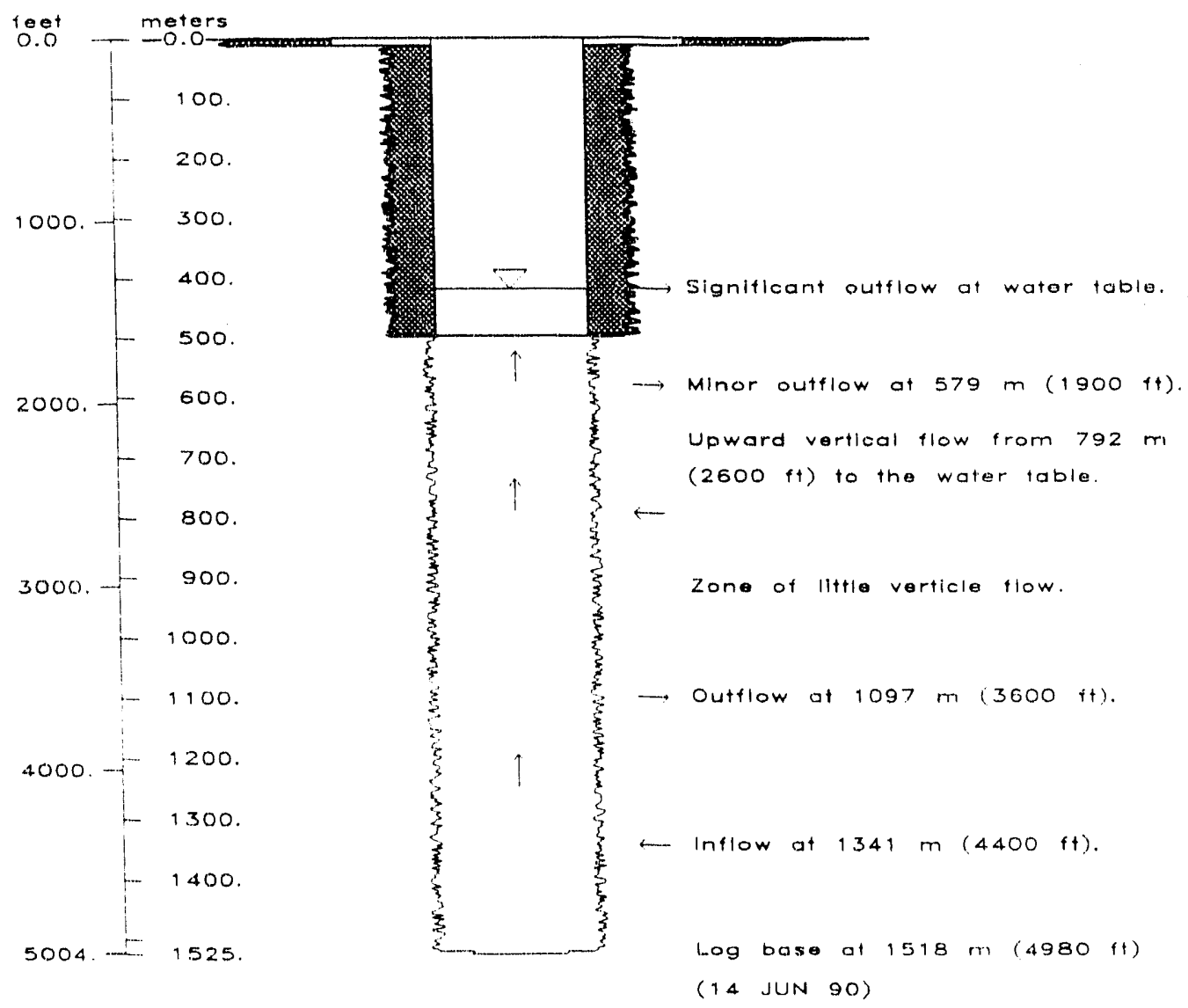

Figure 6. Preliminary Summary of Thermal Flowmeter Results for Well UE18r. 


\section{Conclusions}

Given the downgradient location of UE18r from testing activities on Pahute Mesa, a detailed understanding of the hydrogeology is critical so that monitoring data can be analyzed properly. Currently, water samples are collected from UE18r every six months by the EPA from the upper flow zone $(507 \mathrm{~m}$ (1,663 ft) bls), as part of the LTHMP. Geologic structural complexilies and laterally discontinuous formations may make the lower flow zone just as important as the upper flow zone, from a contaminant transport point of view. Therefore, samples should be collected from two intervals: 686 and $1,219 \mathrm{~m}(2,250$ and $1,000 \mathrm{ft}) \mathrm{bls}$.

Based on the thermal flowmeter data, the composite water level measured in the well should be considered a minimum water level for the aquifers encountered, and a packer and transducer should be set at $421 \mathrm{~m}(1,380 \mathrm{ft})$ and the shut-in pressure monitored so that a true composite head can be computed.

\section{Recommendations}

1. Collect water samples from four depths for major ions and environmental isotopes: $418,762,914$, and $1,219 \mathrm{~m}(1,370,2,500,3,000$, and $4,000 \mathrm{ft})$.

2. Set a packer at $421 \mathrm{~m}(1,380 \mathrm{ft})$ and use the shut-in pressure to compute a true composite head.

3. Upon review of geochemical samples and head measurements (from steps 1 and 2 above), recommendations should be made with regard to future work at well UE18r.

\section{WELL: UEGe}

\section{General Background}

Well UE6e is an exploration hole in Yucca Flat (N. 248,095 m, E. 209,753 m) at a land surface elevation of $1,199.5 \mathrm{~m}(3,935.6 \mathrm{ft})$ above mean sea level (Figure 1). The well was presumably drilled to explore the hydrogeology of southern Yucca Flat. The well intersected alluvium, volcanic tuff, and Paleozoic carbonate rocks.

\section{Construction Details}

The following summarizes the hole history received from Fenix and Scisson, Nevada. Appendix D contains this document and Figure 7 illustrates a schematic of the well.

Well UE6e was spudded on February 27,1973 . A $91.4 \mathrm{~cm}$ (36-inch) hole was drilled to $37 \mathrm{~m} \mathrm{(120} \mathrm{ft),} \mathrm{and} \mathrm{a} \mathrm{49.5-cm} \mathrm{(19.5-inch)} \mathrm{inside--diameter} \mathrm{surface} \mathrm{casing} \mathrm{was} \mathrm{set} \mathrm{in} \mathrm{place} \mathrm{with}$ 

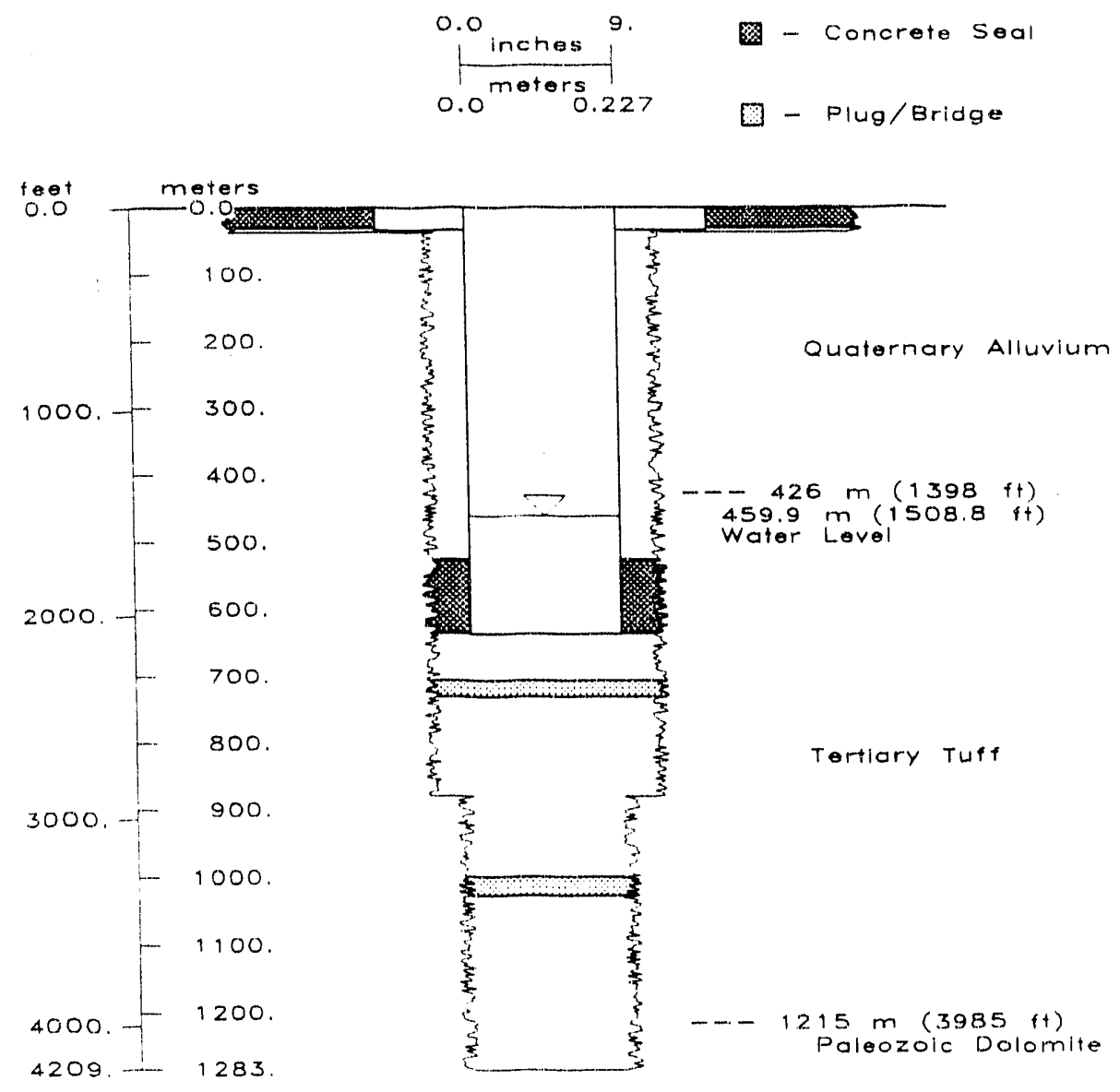

Figure 7. Generalized Schematic of Well UE6e. 
$21 \mathrm{~m}^{3}$ (760 cubic feet) of cement. A 31.1-cm (12.25-inch) hole was then drilled to $880 \mathrm{~m}(2,886$ $\mathrm{ft}$ ); $22.7-\mathrm{cm}$ (8.921-inch) inside-diameter casing was set in place with $18.3 \mathrm{~m}^{3}$ (645 cubic feet) of cement, from the surface to a depth of $637 \mathrm{~m}(2,090 \mathrm{ft})$. A 22.2-cm $(8.75$-inch $)$ hole was then drilled 1,283 $\mathrm{m}(4,209 \mathrm{ft})$; the hole was left uncased from 637 to $1,283 \mathrm{~m}(2,090)$ to 4,209 $\mathrm{ft})$. Hole stability problems were mentioned in the daily summaries and several bridges were drilled out during the completion of the well. The well was completed on December 3, 1973, at a depth of $998 \mathrm{~m}(3,275 \mathrm{ft})$.

\section{Role in Well Validation Program}

Well UE6e is located hydrologically downgradient from the Yucca' ilat underground testing area. Slightly elevated tritium concentrations have been observed in wells near UE.6e, at Well A and Test Well B. Similar elevated tritium values would be expected in UE6e in the alluvium and volcanic rocks; additionally, UE6e may provide an opportunity to study the poorly monitored carbonate aquifer. Paleozoic rocks are believed to convey water beneath the NTS, basically from the northeast toward the southwest. A thorough understanding of the interaction between the regional carbonate aquifer and the overlying aquifer(s) is imperative to adequately monitor the carbonate aquifer for possible radionuclide migration.

Well UE6e intersected $417 \mathrm{~m}(1,368 \mathrm{ft})$ of alluvium, $798 \mathrm{~m}(2,617 \mathrm{ft})$ of volcanic tuff and $68 \mathrm{~m}(223 \mathrm{ft})$ of Paleozoic carbonate rocks; a lithologic description was included in a report by Fernald et al. (1975). The lithologic log contains detailed descriptions of the alluvium, identifies the volcanic units (Timber Mountain Tuff, Paintbrush Tuff, Rhyolites of Area 20, Tunnel Beds, Redrock Valley Tuff, and Horse Springs Formation), and postulates the carbonates to be from the Devonian Nevada Formation. No known hydrologic tests were conducted on UE6e; however, numerous electrical logs were run during construction of the well.

\section{Recent Activities at UE6e (1990)}

In June 1990, UE6e was visited by DRI and the USGS, Denver. Using DRI equipment, the water table was measured at a depth of $460 \mathrm{~m}(1,508.8 \mathrm{ft})$ and an obstruction was encountered at $704 \mathrm{~m}(2,308.2 \mathrm{ft})$. A sample was bailed from the well and analyzed with a portable field scintillation counter. The analysis did not reveal unusually high tritium activities in the water. A sample was collected for laboratory tritium analysis to compare with results from Well $A$ and Test Well B (analysis results were received upon publication of this document). The USGS ran a caliper log and used the thermal flowmeter to identify possible vertical flow. Preliminary field notes collected by DRI suggested that little or no vertical flow existed in the $66 \mathrm{~m}(216 \mathrm{ft})$ of available open hole explored by the USGS. 


\section{Conclusions}

Well UE6e is of hydrologic importance for two reasons: 1) its downgradient location from underground testing on Yucca Flat makes it an excellent location for monitoring potential radionuclide migration; and 2) its completion into the Paleozoic carbonate rocks provides an opportunity to measure the interaction between the regional carbonate aciuifer and the overlying aquifers. Caliper logs run during construction and after completion of the well, and based on the vast number of reported slough zones during construction, suggest that the well was unstable prior to completion; therefore, the obstruction encountered at $703 \mathrm{~m}(2,30) \mathrm{ft}$ ) is believed to be a slough or earthen bridge. Although the well may contain several bridges, it may be acting as a conduit between the alluvial/volcanic aquifer and the regional carbonate aquifer.

The thermal flowmeter data were inconclusive due, in part, to the limited amount of open hole that could be examined. It is possible that UE6e is in a regional hydrologic setting where vertical flow may not be occurring; hcivever, without more open hole, no conclusion can be drawn from the available data.

\section{Recommendations}

1. Clean out hole from 637 to $1,283 \mathrm{~m}(2,090$ to $4,209 \mathrm{ft})$ and install sliding sleeve casing to maintain access to the well. The carbonate rock aquifer should be isolated from the overlying aquifers. Sleeved sample ports should be installed at multiple depths based on thermal flowmeter results, lithology, and chemical/isotopic variations. If this is cost prohibitive, then tubing should be installed to the carbonate aquifer and the upper portion of the hole sealed.

2. Collect water samples from each aquifer delineated in recommendation 1 as part of the LTHMP; at a minimum, two samples should be collected, one from the carbonate and one from the overlying aquifers.

\section{WELL: HTH-3}

\section{General Background}

Hydrologic Test Hole 3 (HTH-3) is one of a group of wells drilled in the early 1960)s to explore general hydrologic conditions around the NTS. It is located outside the NTS boundary in the eastern part of Frenchman Flat (N. 228,646 m, E. 224,607 m). The site is currently part of the Nellis Air Force Base Bombing and Gunnery Range. The well is on the flank of the Ranger Mountains, at an elevation of $1,060 \mathrm{~m}(3,477 \mathrm{ft})$ above sea level (Figure 1). 


\section{Construction Details}

Drilling of HTH-3 began on March 22, 1962 and was completed on May 11, 1962. The hole history can be found in Appendix E. The well was drilled to a depth of $565 \mathrm{~m}(1,853 \mathrm{ft})$ with air-rotary drilling equipment. A $34.0-\mathrm{cm}\left(13^{3} / 8\right.$-inch) outside-diameter casing was installed from 0 to $50 \mathrm{~m}(163 \mathrm{ft})$ and $17.8-\mathrm{cm}$ (7-inch) outside-diameter casing with a Baker shoe in the bottom was installed from 0 to $462 \mathrm{~m}(1,517 \mathrm{ft}$ ) bls (Figure 8). The casing is slotted between 364 and $462 \mathrm{~m}(1,193$ and 1,516ft) bls. The hole was apparently left open between 462 and $565 \mathrm{~m}(1,516$ and $1,853 \mathrm{ft})$ bls, though the shoe prevents sounding below $462 \mathrm{~m}(1,516 \mathrm{ft})$ to verify this.

Electric, neutron, induction, temperature, sonic, caliper, and densily logs were run in the well between May 3 and 8, 1962. Twenty-six cores were collected during the drilling operation, with generally good recovery (Appendix E). The well penetrated Quaternary/Tertiary-age alluvium from 0 to $48 \mathrm{~m}(157 \mathrm{ft}$ ) bls, and limestone, dolomite, and shale of Paleozoic age from 48 to $565 \mathrm{~m}$ (157 to $1,853 \mathrm{ft}$ ) bls. The Pogonip Group, the Goodwin Formation, and Windfall Formation were tentatively identified in the Paleozoic rocks (Meyer and Young, 1962).

A water level of $337 \mathrm{~m}(1,105.8 \mathrm{ft})$ bls was measured during drilling when the hole was $373 \mathrm{~m}(1,225-\mathrm{ft})$ deep. Meyer and Young (1962) report a static water level in the well of 336 $\mathrm{m}(1,103 \mathrm{ft}) \mathrm{bls}$, presumably after completion to the final depth. They also report that packer tests
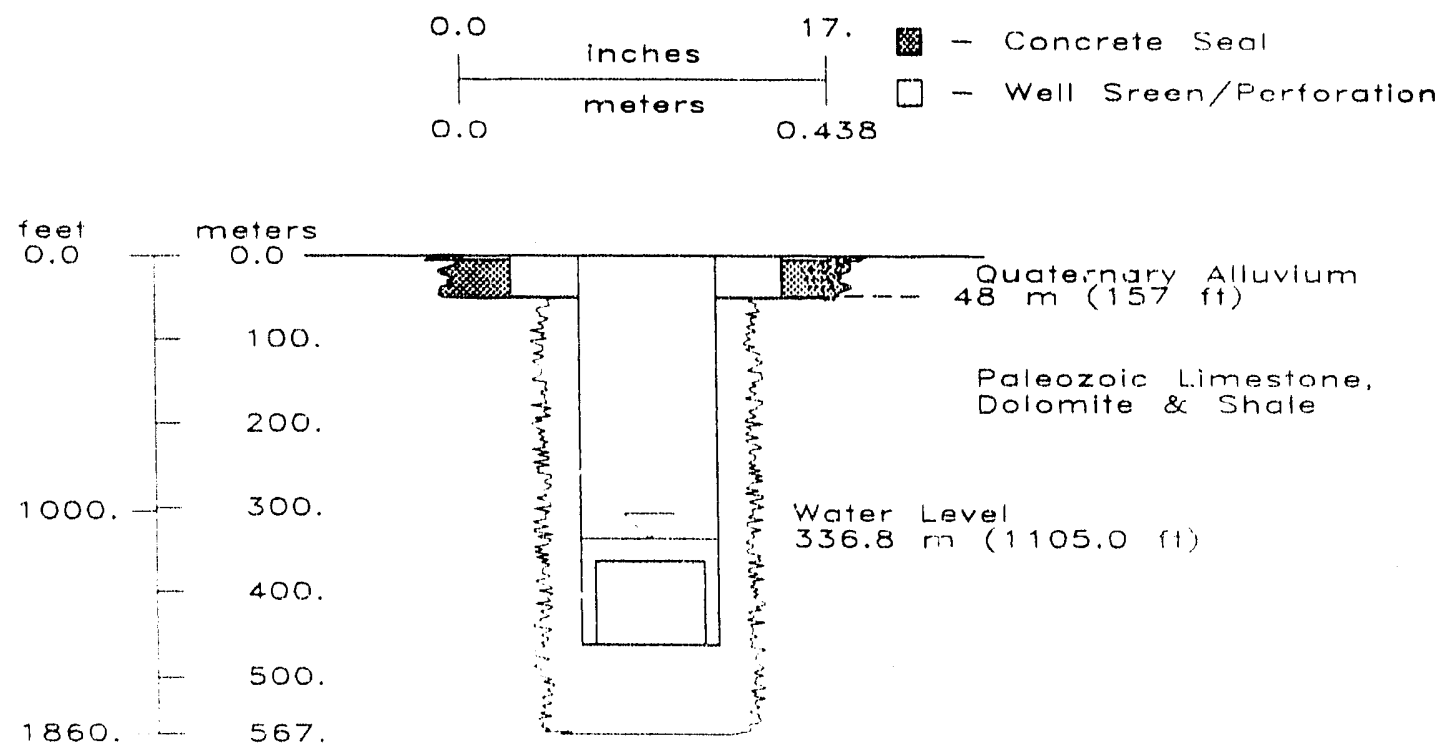

Figure 8. Generalized Schematic of Well HTH-3. 
in the intervals 441 to $519 \mathrm{~m}(1,448$ to $1,702 \mathrm{ft})$ and 491 to $519 \mathrm{~m}(1,612$ to $1,7() 2 \mathrm{ft})$ indicated the same head.

A high transmissivity zone was identified in the interval from 371 to $415 \mathrm{~m}(1,217$ to 1,360 ft) bls during swabbing tests. A pump test was performed from May 9 to 10, 1962, with a Reda submersible pump set at $415 \mathrm{~m}(1,360 \mathrm{ft})$. Discharge rates were $1.8,2.6$, and $3.0 / \mathrm{ps}(29,41$, and $48 \mathrm{gpm})$, and specific capacity ranged from $0.10100 .13 / \mathrm{ps} / \mathrm{m}(0.5100 .64 \mathrm{gpm} / \mathrm{ft})$ of drawdown. The well was considered capable of yielding at least $2.5 \mathrm{lps}(40 \mathrm{gpm})$. A water sample was collected at the end of the pump test and analyzed by the USGS.

\section{Hydrogeologic Setting}

HTH-3 is of great interest to the well validation project because of its completion in the Paleozoic carbonates and location on the east side of the NTS. On the frequently-referenced potentiometric map by Winograd and Thordarson (1975), the only data point that supports the curving of potentiometric contours that creates the southerly-directed potentiometric surface trough in the carbonate rocks along the axis of Yucca Flat, is the water level in HTH-3 (Figure 9). The head measured at HTH-3 was identical to that at Well C, over $16 \mathrm{~km}$ (10 miles) away. Not only is verifying the hydraulic head and what unit it represents important at $\mathrm{HTH}-3$, the well also provides access to the regional carbonate aquifer in an area undisturbed by NTS activities. Obtaining a reliable age for water from $\mathrm{HTH}-3$ could greatly aid regional flow and transport analysis of the NTS.

The apparent upgradient position of $\mathrm{H} T \mathrm{TH}-3$ from the NTS testing areas makes the well attractive for determining background chemical and radiochemical characteristics for the curbonate aquifer. The well could also eventually serve as an upgradient monitoring well in the NTS monitoring network.

\section{Recent Activities at HTH-3 (1990)}

There is no record in the Fenix and Scisson hole history of any activities at HTH-3 since 1962. Little has been done at the well in large part due to the difficulty in coordinating access belween the NTS and Air Force property. Water levels were apparently measured by the USGS in $1963(336 \mathrm{~m}(1,103.4 \mathrm{ft})$ bls on $1 / 25 / 63)$, and reportedly in the $1980 \mathrm{~s}$, though no record of this last visit could be found.

DRI and the US SS-Las Vegas visited HTH-3 on June 9, 1990. Rather than the $17.8-\mathrm{cm}$ (7-inch) diameter open well expected, $7.3-\mathrm{cm}(2 \% / 8$-inch) tubing was extending from the hole, with a large discharge pipe over the entire well bore, leading to a pit north of the well. No record 


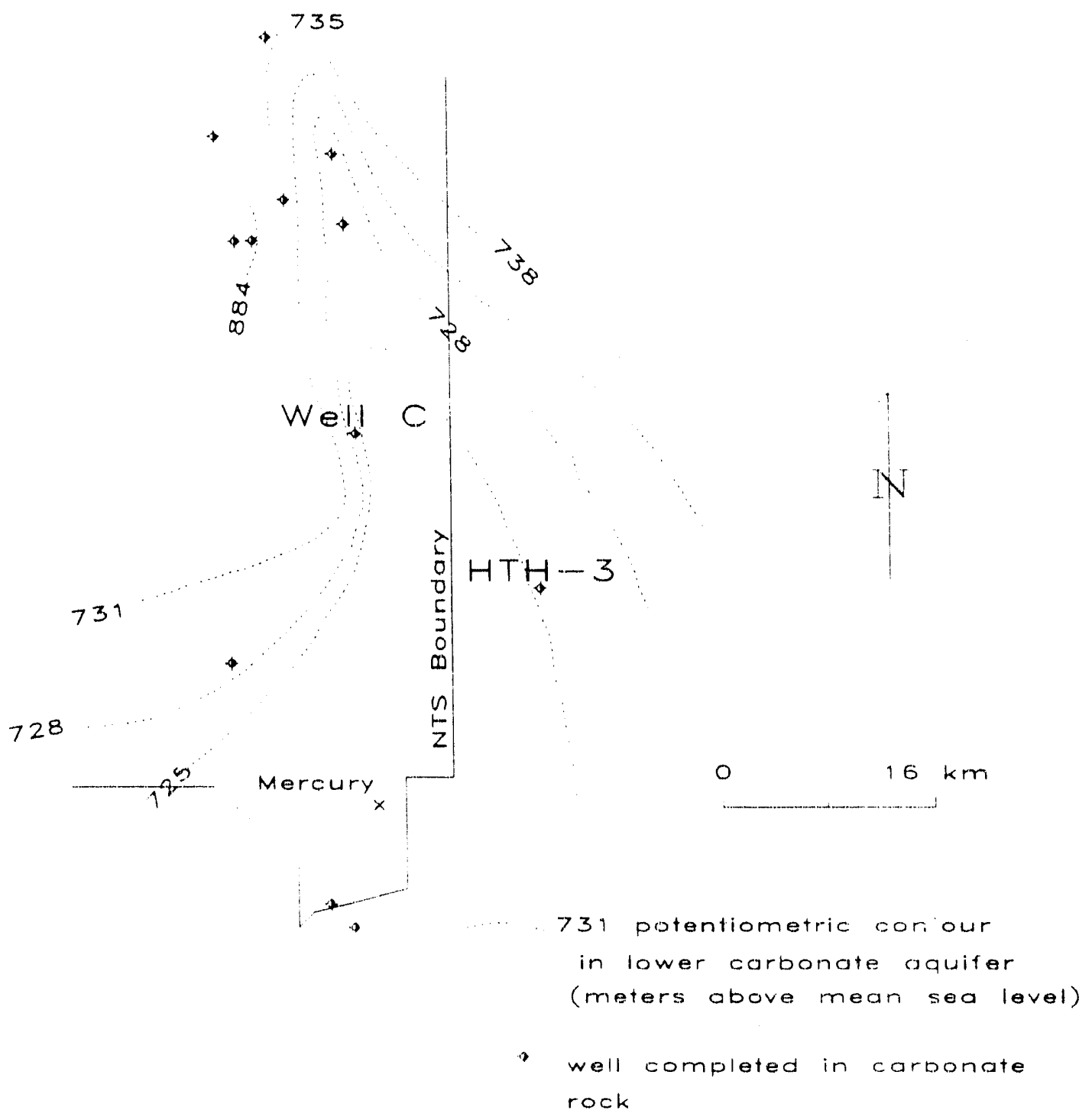

Figure 9. Generalized Potentiometric Surface Map of Carbonate Aquifer Near Well H7H-3. 
of this material being installed at HTH-3 could be found, nor could personnel at the USGS, DRI, or Fenix and Scisson recall any activities there. The tubing and discharge pipe suggest that airlifting was performed at HTH-3, but when and why this was done remain unknown.

Access into HTH-3 is currently possible only through the $7.3-\mathrm{cm}\left(2^{7} / 8-\mathrm{inch}\right)$ tubing. This prohibited use of the USGS-Denver geophysical tools and DRI's Bennett sampling pump. The witer level on 6/9/90 measured by the USGS-Las Vegas and DRI was $337 \mathrm{~m}(1,105 \mathrm{ft}) \mathrm{bls}$, comparable to the measurements during and shortly after drilling. DRI tagged the bottom of the well at $4.59 \mathrm{~m}(1,507 \mathrm{ft})$, reasonably consistent with the location of the Baker shoe.

DRI collected water samples on 6/9/90 and 6/16/90. Oil was encountered at the top of the water column, but efforts to remove it by bailing had limited success.

Purging and clearing of the well would normally precede water sampling, but given the difficulty of gaining access to the site and uncertainty as to when it could be sampled in the future, the maximum possible quantity of water was collected. The chemical analysis of the June 1990 samples compares favorably with the 1962 analysis (Table 3). Tritium activity, determined using enrichment techniques, was found to be le is than $10 \mathrm{pCi} / \mathrm{L}(<3.1$ Tritium Units), indicating that the water in the well was recharged befo.e 1953. A sample was collected for carbon-14 analysis but the results were not received as of the writing of this report (the sample was sen to the University of Arizona for analysis because the presence of the tubing and limited time-of-access prohibited collection of the large sample volume required for a standard carbon-14 analysis).

\section{Conclusions}

The stable water level measured in HTH-3 and total depth consistent with the Baker shoe in the bottom of the casing suggest that structurally, HTH-3 is in good condition. There remains uncertainty as to the condition of the hole from the shoe to the total drilled depth. The comparable 1962 and 1990 chemical analyses further supports the integrity of the well. The oil encountered may be a residue from earlier pumping activities.

TABLE 3. CHEMICAL ANALYSIS FOR HTH-3 (concentration in $\mathrm{mg} / \mathrm{L}$ and $\mathrm{EC}$ in $\left.\mu \mathrm{mhos} / \mathrm{cm} @ 25^{\circ} \mathrm{C}\right) . \mathrm{F}=$ FIELD MEASUREMENT.

\begin{tabular}{|c|c|c|c|c|c|c|c|c|c|c|c|c|c|c|c|}
\hline Ditte & Source & $\begin{array}{l}\text { Temp } \\
\left({ }^{\circ} \mathrm{C}\right)\end{array}$ & $\mathrm{pH}$ & $\mathrm{HCO}_{3}$ & $\mathrm{Cl}$ & $\mathrm{SO}_{4}$ & $\mathrm{NO}_{3}$ & $\mathrm{Na}$ & $\mathrm{K}$ & $\mathrm{Ca}$ & $\mathrm{Mg}$ & $\mathrm{SiO}_{2}$ & $\mathrm{Fc}$ & $\mathrm{Sr}$ & ${ }^{3} \mathrm{H}$ \\
\hline $5 / 11) / 12$ & USGS & 38 & 7.3 & 328 & 23 & 84 & 0.9 & 83 & 7.6 & 51 & 21 & 24 & & & 0.12 \\
\hline$f i / 16 / \%)$ & DRI & & 8.27 & 343 & 23.2 & 66.8 & $<(1.04$ & 79.6 & 9.18 & 48.8 & 19.7 & 17.4 & 0.12 & 0.89 & $0.11<10 \mathrm{p} \times \mathrm{C} / \mathrm{L}$ \\
\hline$f_{1} / 3\left(f_{1} /()\right)$ & DRI & $34.5 \mathrm{~F}$ & $7.4 \mathrm{~F}$ & $323 \mathrm{l}$ & & & & & & & & & & & \\
\hline
\end{tabular}




\section{Recommendations}

1. Remove the tubing and discharge pipe assembly from HTH-3 to allow free access into the well.

2. Evaluate drilling out the Baker shoe in the bottom of the $17.8-\mathrm{cm}$ (7--inch) casing to allow geophysical logging (USGS teleseismic viewing) of the open hole. This would also allow confirmation of the hole condition between 462 and $565 \mathrm{rr}, 1,517$ and 1,853 $\mathrm{ft}$ ) bls, but should only be done after a thorough records search to contirm that the horizon was not cemented.

3. Perform a long-term pump test to measure hydraulic properties, clean out the well, and collect a purged water sample.

4. Maintain well integrity (e.g., add a locking cap) and add the well to the LTHMP network.

\section{PIIASE II TESTING PROCEDURES}

Phase II testing procedures were developed for each well based on historical information and the results of Phase I testing.

Phase I testing at HTH-1 yielded valuable information about vertical flow in the well, and water samples collected from discrete depths indicated slightly elevated tritium concentrations near the water table. Phase II testing procedures are as follows:

1. Repeat thermal flowmeter measurements at each depth previously made in Phase I testing, to evaluate the long-term repeatability of thermal flowmeter measurements, and to make additional measurements between each of these points and at the bottom of the hole, to help quantify the downward flux in the hole.

2. Collect water samples from four discrete depths near the water table to verify that the elevated tritium that was encountered in Phase I testing is still of the same magnitude, and secondly, to more accurately measure the vertical extent of the elevated tritium in the well. This information will be used to develop hypotheses about the origin of the tritium and its flow path into the well.

3. Based on information from Phase I testing and from the above mentioned measurements, a recommendation will be made regarding the most appropriate depth from which samples should be collected for long-term hydrologic monitoring and/or recompletion of the well. 
Phase I testing at UE18r also yielded interesting information about vertical flow in the wel!, both within the cased and uncased portions of the hole. Two aquifers were identified during Phase I testing and a potential outflow zone may have been identified in the casing at the water table. Phase II testing procedures will be developed to iurther understand the hydraulic and gcochemical significance of the Phase I results.

1. Repeat thermal flowmeter measurements near the water table to more accurately quantify the extent of outflow through the casing. Repeat measurements will also be made at the same depth as Phase I testing to measure potential time-series variations of flux.

2. Collect water samples from four depths for major cations and anions, trace ions, and environmental isotopes. Samples will be collected near the water table, from the upper and lower flow zones, and from the stagnation zone between the two flow zones. These data will be used to quantify the geochemical similarities and differences between the two aquifers.

3. Currently, EPA collects water samples from $508 \mathrm{~m}(1,665 \mathrm{ft})$ bls, which is $11 \mathrm{~m}(35$ $\mathrm{ft}$ ) below the bottom of the casing. Based on the results from Phase I testing and the above mentioned measurements, a recorimendation will be made regarding the depth(s) from which samples should be collected as part of the LTHMP.

Phase II testing of Wells UE6e and HTH-3 will require the removal of debris and/or hardware from each well, which is beyond the scope and monetary constraints of this study. However, the sieps necessary to complete Phase II testing at these sites will be covered for completeness.

Phase I testing at UE6e yielded limited results, due to the small amount of open hole encountered between the bottom of the casing and an earthen bridge (approximately $61 \mathrm{~m}(200)$ ft)). These findings were regrettable due to the hydrologic importance of the well, for monitoring of radionuclide migration and for measuring the hydrologic interaction between the volcanic and carbonate rocks. Although a bridge was encountered at $703 \mathrm{~m}(2,308 \mathrm{ft})$ bls, the integrity of the remaining hole is unclear, and may be acting as conduit for radionuclide migration between the volcanic and underlying carbonate aquifers. Since the carbonate aquifer is believed to be the most probable transport path for radionuclides off the NTS, it is important that at a minimum the well be cleaned out and that the carbonate aquifer is sealed off from the volcanic aquifers. It is further recommended that a piezometer be installed into the carbonate aquifer prior to setting this seal for long-term monitoring of the carbonate aquifer, and to fully utilize this well a piezometer should be installed in the volcanic aquifers to measure the interaction 
between the two aquifers. Once the hole is cleaned out, the following Phase II testing procedures are recommended.

1. Log the hole for temperature, EC, and caliper. Compare the logging results to previously recorded information and outline areas of interest for thermal flowmeter measurements. Conduct thermal flowmeter measurements and recommend piezometer completion depths.

2. Collect discrete water samples from each aquifer prior to piezometer installation.

3. Oversee piezomete: installation.

4. Collect bulk samples from each piezometer with a low volume 4 amp once the EC and $\mathrm{pH}$ have stabilized, and analyze the samples for radionuclide contamination.

5. Develop a monitoring plan for water level measurements and for sampling based on results from the above steps.

Phase I testing at HTH-3 was hampered by the presence of tubing in the well, restricting access into the hole. Despite this limitation, a water sample was collected with a sr uall discrete bailer and yielded a chemical analysis similar to that obtained when the well was drilled and tested in the early 1960s. This result suggests that downhole conditions have remained chemically stable and this stability, along with the well's geographic and stratigraphic location, mal a. HTH-3 an excellent candidate for monitoring background conditions in the carbonate aquifer. Also important is the acquisition of high quality samples after purging for determining the age of the water because the well is postulated to be on a very long flow path, with recharge possible in the Pahranagat Lakes area. Obtaining an age date and hydraulic properties from HTH-3 will be important for establishing boundary conditions on the east side of the NTS for regional flow analysis.

The following actions are recommended at HTH-3 outside the scope of this study:

1. Evacuate the well by air lifting prior to removing the tubing (the tubing in $\mathrm{HTH}-3$ and piping leading from the well head to a surface pit appear suitable for an airlifting operation). This will purge the well and eject the layer of oil currently on the top of the water column.

2. Remove the tubing from HTH-3 and run a caliper log to evaluate downhole cond:tions.

3. Consider drilling out the Baker shoe at the bottom of the casing. 
Once these activities are complete, the following Phase II testing procedures are recommended:

1. Monitor water level rise in the well after air lifting.

2. Log the hole for temperature and EC and conduct thermal flowmeter measurements to establish vertical flow directions in the hole.

3. Collect discrete water samples from producing horizons identified in step number 2 .

4. Collect a large volume sample from one or more horizons (depending on previous results) for Carbon-14 analysis. This will be done using a low-volume pump (e.g., Bennett pump).

5. Provide the LTHMP with necessary information to add $\mathrm{H}$ TH-3 to the monitoring program.

\section{ACKNOWLEDGEMENTS}

The authors would like to thank Al Hess, Roger Morin, and Barbara Allen from the U.S. Geological Survey for coming out from Denver and running their thermal flowmeter tool.

Additionally, the authors thank, Sam Hokett for overseeing the DRI logging activities and reviewing this document, Todd Miheve and Bruce Wert for helping with field data collection, and Roger Jacobson for coordinating activities with DOE. 


\section{REFERENCES}

Blankennagel, R.K. and J.E. Weir, 1973. Geohydrology of the Eastern Part of Pahute Mesa, Nevada Test Site, Nye County, Nevada, U.S. Geological Survey, Prof. Paper 712-B, pp. 35.

Boughton, C.J., 1986. Integrated Geochemical Analyses of Nevada Test Site Ground Water Systems, unpublished Master's Thesis, University of Nevada, Reno.

Carr, W.J., F.M. Byers and E.C. Jenkins, 1968. Geology of Drill Hole UE18r, Timber Mountain Caldera, Nevada Test Site, U.S. Geological Survey, Technical Letter, Special Studies-69, pp. 23.

Feeney, T.A., M.E. Can'pana and R.L. Jacobson, 1987. A Deuterium-Calibrated Groundwater Flow Model of the Western Nevada Test Site and Vicinity, 1987, Desert Research Institute, Water Resources Center, Publication No. 45057.

Fernald, A.T., F.M. Byers and J.P. Ohl, 1975. Lithologic Logs and Stratigraphic Units of Drill Holes and Mining Shafts in Areas 1 and 6, Nevada Test Site, U.S. Geological Survey, NTS-256, USGS-474-206, pp. 62.

Meyer, G.L. and R.A. Young, 1962. Summary of Hydraulic Data and Abridged Log for Ground-Water HTH-3, Frenchman Flat, Nevada Test Site, U.S. Geological Survey, Technical Letter NTS-30.

Morin, R.H., 1990. Personal communication, U.S. Geological Survey, Geophysicist, Denvcr, Colorado.

Morin, R.H., A.E. Hess and F.L. Paillet, 1988. Determining the Distribution of Hydraulic Conductivity in a Fractured Limestone Aquifer by Simultaneous Injection and Geophysical Logging, Groundwater, Vol. 26, No. 5, pp. 587-595.

Thordarson, W. and I.J. Winograd, 1961. Abridged Log of Ground-Water Test Well 1 Stockade Wash, Nevada Test Site, Nevada, U.S. Geological Survey, Technical Letter, NTS-6.

Waddell, R.K., 1982. Two-Dimensional, Steady-State Model of Ground Water Flow, Nevada Test Site and Vicinity, Nevada-California, U.S. Geological Survey, W.R.I. 82-4085.

Winograd, I.J. and W. Thordarson, 1975. Hydrogeologic and Hydrochemical Framework, South-Central Great Basin, Nevada-California, with Special Reference to the Nevada Test Site, U.S. Geological Survey Professional Paper 712-C, pp. 126. 


\section{APPENDIX A}

Hole History Data for HTH-1

(Fenix and Scisson, Nevada) 


\section{FENIX \& SCISSON OF NEVADA HOLE HISTORY DATA}

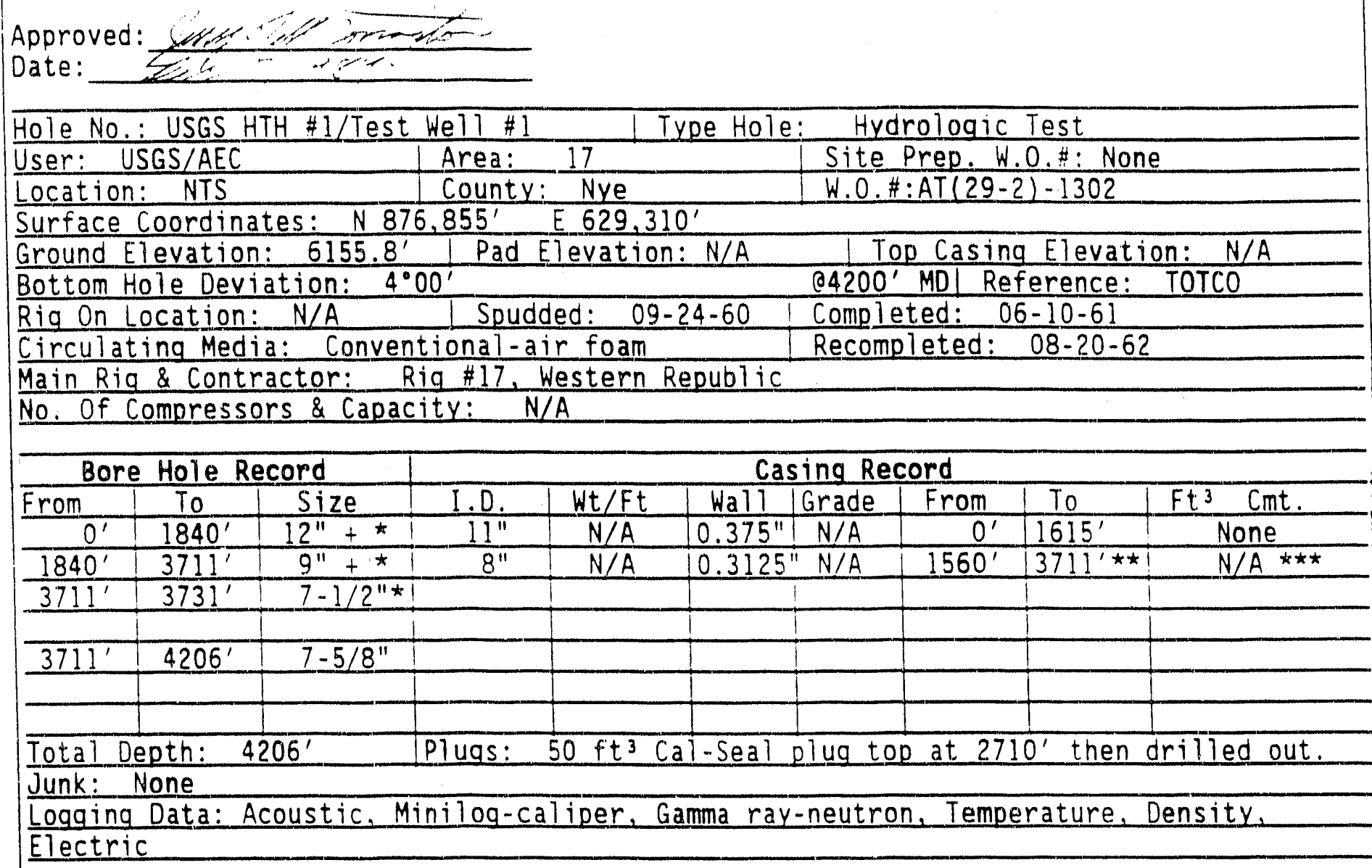

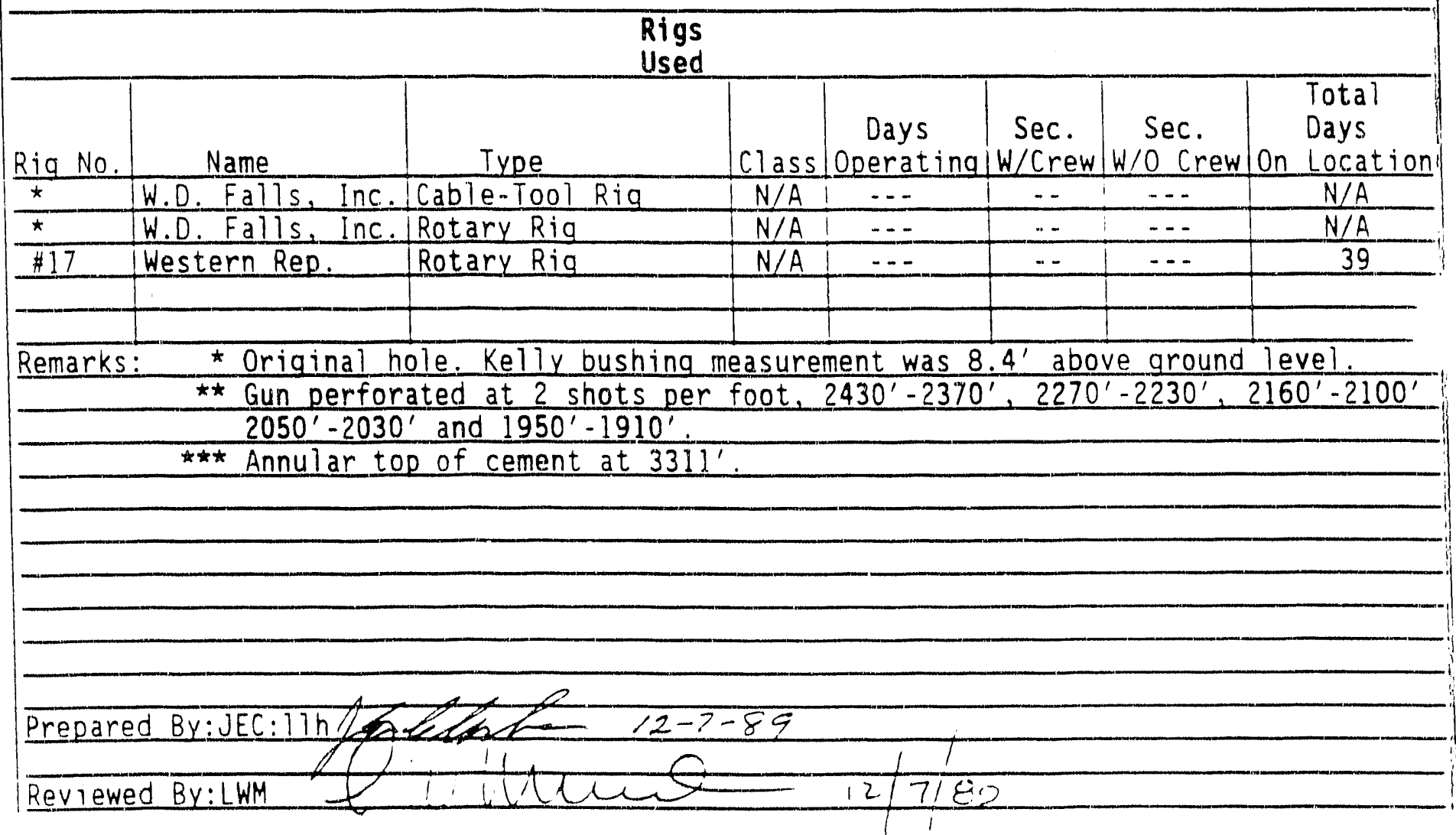




\section{USGS HTH \#1/Test Well \#1 \\ Area 17 \\ ORIGINAL WORK SUMMARY}

09-24-60 Spudded 09-24-60. D. W. Falls, Inc. was contractor.

$12^{\prime \prime}+$ hole was drilled to $1840^{\prime}$ using a cable-tool rig. 11-3/4" 0.0., 3/8" wall casing was set at 1615'. 9" + hole was drilled to $3711^{\prime}$ with a rotary rig using conventional air foam circulation. 8-5/8" 0.D., 5/16" wall liner was set at $3717^{\prime \prime}$ with Burns liner hanger top at $1560^{\prime}$ and the annulus cemented to $3311^{\prime}$ using Haliburton. 7-1/2" hole was either drilled or cored to $3731^{\prime}$.

Measurements are from kelly bushing, $8.4^{\prime}$ above ground surface.

Fluid level was at $412^{\prime}$ when hole was at $560^{\prime}$. Fluid level was at $1033^{\prime}$ after casing was set at $1615^{\prime}$ and hole drilled to $1840^{\prime}$ using cable-tools.

08-10-61 Hole completed 06-10-61.

\section{USGS HTH \#1/Test Well \#1 DEEPENING WORK}

(Information from "Daily Drilling Reports". Time interval, approximately 0700 hours to 0700 hours.)

07-12-62 Moved in Western Republic rig \#17 and started rigging up.

$07-13-62$ Continued rigging up.

07-14-62 Continued rigging up.

07-15-62 Continued rigging up.

07-16-62 Continued rigging up and secured rig.

07-18-62 Rig secured from 07-15-61 to 1200 hours 07-17-61. Cont inued rigging up.

07-19-62 Continued rigging up.

07-20-62 Completed rigging up. Started in the hole with 7-5/8" drilling assembiy on 3-1/2" drill pipe, tagged top of liner at $1560^{\prime}$.

07-21-62 Cleaned out liner to 3708'. Made trip to remove drilling assembly. Pumped in $50 \mathrm{ft}^{3}$ of Hydrogel at 1868'. Pumped in $25 \mathrm{ft}^{3}$ Cal-Seal plug with opened drill pipe at 1708'. Made trip for 7-5/8" drilling assembly, tagged plug at $1665^{\prime}$, and filled casing with water. Fluid level dropped at 1' per hour. Set Baker squeeze tool at $1394^{\prime \prime}$. Pumped in $40 \mathrm{ft}^{3}$ of water in 2 minutes at $300 \mathrm{psi}$, pressure at zero in 2 minutes. 
USGS HTH \#1/Test Well \#1

Hole History

Page 2

07-22-62 Pumped in $150 \mathrm{ft}^{2}$ of $50 \%$ cement \& 50\% Pozmix at top of 8-5/8" 1 iner. Pressure tested squeeze job at $250 \mathrm{psi}$. Tagged top of cement inside $11-3 / 4 "$ casing at $1470^{\prime}$ using $9-7 / 8 "$ bit.

07-23-62 Drilled cement to 4 ' below top of 1 iner and pressure tested 8-5/8" liner and 11-3/4" casing 1 ap to 300 psi for 30 minutes. Drilled $\mathrm{Cal}$ Seal plug and opened $7-1 / 2^{\prime \prime}$ hole to $7-5 / 8^{\prime \prime}$ to $3720^{\prime}$.

07-24-62 Opened 7-1/2" hole to 7-5/8" to 3729' and drilled on junk to 3730'. Recovered small pieces of junk using junk basket. Recovered small pieces of metal on 2 runs using a 7" magnet. Drilled 7-5/8" hole to $3753^{\prime}$ using air foam.

07-25-62 Cut 7-1/2" core hole from 3753' to $3757^{\prime}$ using diamond corenead, 4' \#1 core recovery. Opened core hole and drilled 7-5/8" hole from $3757^{\prime}$ to $3787^{\prime}$. Deviation survey at $3750^{\prime}=3^{\circ} 45^{\prime}$.

07-26-62 Drilled 7-5/8" hole from $3787^{\prime}$ to $3808^{\prime}$. Cut $7-1 / 2^{\prime \prime}$ core hole to $3824^{\prime}, 1^{\prime} \# 2$ core recovery. Started running USGS swab test using $3-1 / 2$ " tubing at 0400 hours.

07-27-62 Swab tested at 2600' to 1200 hours, static fluid level at $1986^{\prime}$. Opened core hole and drilled 7-5/8" hole from 3808' to 3868'.

07-28-62 Drilled 7-5/8" hole from 3868' to $3924^{\prime}$ using air.

07-29-62 Cut 7-1/2" core hole from $3924^{\prime}$ to $3934^{\prime}, 2^{\prime}$ \#3 core recovery. Ran swab test with 3-1/2" tubing at $2730^{\prime}$, static fluid level at $1982^{\prime}$. opened core hole and drilled 7-5/8" hole from $3924^{\prime}$ to $3942^{\prime}$.

07-30-62 Orilled 7-5/8" hole from 3942' to 3971'. Cut 7-1/2" core hole to 3981 ! , 10" \#4 core recovery. Opened core hole and drilled 7-5/8" hole from $3971^{\prime}$ to $4008^{\prime}$.

07-31-62 Drilled 7-5/8" hole from 4008' to 4046'. Deviation survey at 4040' $=3^{\bullet} 30^{\prime}$.

08-01-62 Ran swab test with 3-1/2" tubing and 1-1/2" tubing strapped on outside at 2911' for 2-1/4 hours, static fluid level at 1985'. Worked on sandline drum clutch from 1000 hours.

08-02-62 Repaired clutch and reinstalled sand line at 2000 hours. Ran swab test to 0100 hours, static fluid level at 2040'.

08-03-62 Drilled 7-5/8" hole from 4046' to 4075'.

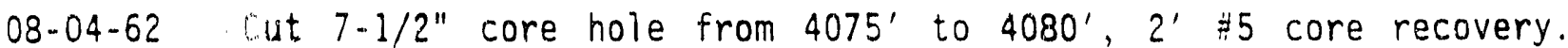
Opened core hole to $7-5 / 8^{\prime \prime}$ hole from $4075^{\prime}$ to $4080^{\prime}$. 
USGS HTH \#1/Test Well \#1

Hole History

Page 3

08-05-62 Drilled 7-5/8" hole from 4080' to 4200'. Ran Lane Wells gamma rayneutron, sonic, electric, densilog, minilog-caliper logs. Deviation survey at $4200^{\prime}=4^{\circ} 00^{\prime}$.

08-06-62 Static fluid level at 1984' (KBM). Ran swab test with 3-1/2" tubing and $1-1 / 2 "$ tubing strapped on outside at $2910^{\prime}$.

08-07-62 Swab tested 6 hours, static fluid level at 1985'. Cleaned out hole to bottom. Cut $7-1 / 2^{\prime \prime}$ core hole from $4200^{\prime}$ to $4206^{\prime}$.

08-08-62 2' \#6 core recovery. Opened core hole to 7-5/8" from 4200' to 4206' T.D. .

08-09-62 Lowered and set Reda pump (100 gpm capacity) on 3-1/2" tubing and 1-1/2" tubing strapped on outside with intake at $2502^{\prime}$. Ran pump test $4-3 / 4$ hours at full capacity, fluid drawdown to $2170^{\prime}$ and static level at 1985'. Started pump test at $50 \mathrm{gpm}$ at 0330 hours.

08-10-62 Completed test at 0900 hours. Fluid drawdown was to $2130^{\prime}$ and static level at $1983^{\prime}$ after 3 hours. Coninued pump test at $100 \mathrm{gpm}$.

08-11-62 Continued pump test. Test stopped 12-1/2 hours for rig repair.

08-12-62 Static fluid level at 1985', tests completed. Set $100 \mathrm{ft}^{3}$ of Hydrogel for plug at $3012^{\prime}$ and $50 \mathrm{ft}^{3}$ of $\mathrm{Cal}$-Seal for plug at $2710^{\prime}$. Tagged plug top at $2710^{\prime}$ and tested to 6000\#. Blew fluid out of casing. Filled casing to $1500^{\prime}$ with water.

08-13-62 8-5/8" liner was gun perforated from $2430^{\prime}$ to $2370^{\prime}, 2270^{\prime}$ to $2230^{\prime}$, $2160^{\prime}$ to $2100^{\prime}, 2050^{\prime}$ to $2030^{\prime}$, and $1950^{\prime}$ to $1910^{\prime}$ using Lane Wells $15 / 32^{\prime \prime}$ bullets at 2 shots per foot. Static fluid level was at $1461^{\prime}$. Made trip in with 7-5/8" bit on 3-1/2" drill pipe and blew out fluid from 1330 hours at $44 \mathrm{gpm}$.

08-14-62 Made trip out and lowered 3-1/2" tubing to 2466'. Ran USGS fluid check, fluid at 1468'. Swab tested hole 3 hours. Ran fluid check, fluid at $1455.6^{\prime}$. Lowered tubing to $2655^{\prime}$ and swabbed hole at 35 gpm. Pulled out tubing.

08-15-62 Lowered and set Reda pump on 3-1/2" tubing at 2443'. Ran fluid check, fluid at $1455^{\prime}$. Pumped out water from 2200 hours to 0500 hours at $25 \mathrm{gpm}$.

08-16-62 Increased pump rate to $50 \mathrm{gpm}$ to 1000 hours. Ran recovery test to 1400 hours, fluid at $1460^{\prime}$. Reslimed pump test.

08-17-62 Ran pump test to 1300 hours and recovery test to 1500 hours, fluid at $1455^{\prime}$. Continued pump test to 0200 hours at $70 \mathrm{gpm}$ and recovery test to 0400 hours, fluid at $1457^{\prime}$. 
USGS HTH \#1/Test Well \#1

Hole History

Page 4

08-18-62 Ran fluid check at 0900 hours, fluid at 1461'. Ran pump test to 1900 hours and recovery test to 2300 hours. Laid down tubing and Reda pump.

08-19-62 Drilled Cal-Seal plug and cleaned hole to 4206' using 7-5/8" bit. Scraped 8-5/8" liner from $1560^{\prime}$ to $2800^{\prime}$ and blew hole clean.

08-20-62 Laid down drill pipe. Lowered and set Baker packer on 27/8" tubing along with 1600' of 1-1/2" tubing strapped on the outside at 2752.62'. Checked fluid level at 1464.8'. Swabbed tested hole for 2 hours. Lain down both strings of tubing and Baker packer. Welded steel plate on top of casing. Rigged down and moved out. Hole recompleted 08-20-62. 


\section{REVIEW OF HOLE CONDITIONS}

$298 \mathrm{~mm}\left(11-3 / 4^{\prime \prime}\right)$ casing was set at $492.3 \mathrm{~m}\left(1615^{\prime}\right)$ in a hole drilled of sufficient size to $560.8 \mathrm{~m}\left(1840^{\prime}\right)$ using a cable-tool rig. A hole of sufficient size was orilled to $1131.1 \mathrm{~m}\left(3711^{\prime}\right)$ using the conventional air foam circulating method. $219 \mathrm{~mm}\left(8-5 / 8^{\prime \prime}\right)$ liner was set at $1131.1 \mathrm{~m}$ (3711') with top of Burns liner hanger at $475.5 \mathrm{~m}\left(1560^{\prime}\right)$ and the annulus cemented to $1009.2 \mathrm{~m}\left(3311^{\prime}\right)$. $191 \mathrm{~mm}\left(7-1 / 2^{\prime \prime}\right)$ hole was either drilled or cored to a total depth of $1137.2 \mathrm{~m}$ $\left(3731^{\prime}\right)$ using the conventional air foam circulating method. USGS hydrologic tests were run during drilling. Hole spudded 09-24-60 and completed 06-10-61. Top of $219 \mathrm{~mm}\left(8-5 / 8^{\prime \prime}\right)$ liner and bottom of $298 \mathrm{~mm}\left(11-3 / 4^{\prime \prime}\right)$ casing annulus was squeezed using $4.25 \mathrm{~m}^{2}\left(150 \mathrm{ft}^{3}\right)$ of $50 \%$ cement \& $50 \%$ Pozmix and pressure tested 07-21-62. The original hole was deepened to $1282.0 \mathrm{~m}\left(4206^{\prime}\right)$ using $194 \mathrm{~mm}$ (7$\left.5 / 8^{\prime \prime}\right)$ drilling assembiy and conventional air foam circulating method between 07 23-62 and 08-09-62. A total of 6 core runs and USGS hydrologic tests were made durin deepening. Lane Wells gamma ray-neutron, sonic, electric, density, and minilog-caliper logs were run 08-05-62 when hole was at $1280.2 \mathrm{~m}\left(4200^{\prime}\right)$. Liner was perforated from $740.7 \mathrm{~m}\left(2430^{\prime}\right)$ to $722.4 \mathrm{~m}\left(2370^{\prime}\right), 691.9 \mathrm{~m}\left(2270^{\prime}\right)$ to $679.7 \mathrm{~m}\left(2230^{\prime}\right), 658.4 \mathrm{~m}\left(2160^{\prime}\right)$ to $640.1 \mathrm{~m}\left(2100^{\prime}\right), 624.8 \mathrm{~m}$ (2050') to $618.7 \mathrm{~m}\left(2030^{\prime}\right)$, and $594.4 \mathrm{~m}\left(1950^{\prime}\right)$ to $582.2 \mathrm{~m}\left(1910^{\prime}\right)$ using Lane Wells wireline bullet guns. Swab and pump tests were run. Baker packer on $64 \mathrm{~mm}\left(2-1 / 2^{\prime \prime}\right)$ tubing along with $487.7 \mathrm{~m}\left(1600^{\prime}\right)$ of $38 \mathrm{~mm}\left(1-1 / 2^{\prime \prime}\right)$ tubing strapped on the outside was set at $839.1 \mathrm{~m}\left(2753^{\prime}\right)$ and 2 hour swab test run. Packer and tubing were removed and steel plate welded on top of casing. Hole recompleted 08-2062. 


\section{HTH \#1 Area 17}

ADDITIONAL WORK

03-02-88 Ran USGS fluid check, fluid level indicated at 1466.7'.

05-02-89 Ran USGS fluid check, fluid at 1465'.

05-04-89 Ran USGS fluid check, fluid at 1465'.

09-18-89 Moved in and rigged up Joy \#l, rig \# 85172. Made trip in with spear on bottom of 2-3/8" Hydril tubing and tagged bottom at 3694'. Started out of hole.

09-19-89 Laid down tubing, spear clean. Rigged down and moved out.

10-04-89 Ran USGS fluid check, fluid at 1465'. 


\section{APPENDIX B}

Nevada Test Site Deep Sampling HTH-1

(Workplan, Todd Mihevc, DRI) 
May 1,1989

\title{
NEVADA TEST SITE DEEP SAMPLING WELL TWI
}

\author{
by \\ Todd Miheve
}

The Desert Research Institute acquired access from DOE to enter Well TW1 (Test Well \#1) in Area 17, to sample six discrete intervals. From previous excursions on ()6/24/86 and $(07 / 21 / 87$, it was learned that the water surface in the borehole had an oil layer on it (probably pump oil) which was bailed clean for sampler access.

On $04 / 25 / 89$, the DRI deep sampling rig was set up at Well TWI again. The first task was to skim the well for oil with an open-top bailer $\left(6^{\prime \prime}\right.$ diameter $\times 5^{\prime}$ long). A total of four skimming runs were made indicating little or no oil left in the well bore. Although, to our surprise, other foreign debris was skimmed from the water surface. The first skim produced a 2" diameter aluminum foil ball and fiber-like scum. The second skim was over-filled clean water. The third skim produced several cellophane pieces $\left(6^{\prime \prime} \times 4^{\prime \prime}\right)$, more aluminum foil, a couple of white/green mold balls and fiber-like scum. The fourth skim produced fairly clear water with some fiber scum.

The discrete interval sample bailer (2 liter) was attached and sent down the hole. Due care was taken, slow winch speeds of approximately 20 feet per minute, at the water table interface at approximately 1,460 feet and the casing narrowing point (from $11^{3} / 4^{\prime \prime} 108{ }^{3} / 4^{\prime \prime}$ ) at 1,1551.5 feet. A total of eleven samples were pulled below the casing narrowing before the problems arose. Of the relevant trips through this opening, only twice was a light bounce observed.

On the twelfth trip down the hole (04/26/89), problems were encountered. The sampling sonde passed through the casing narrowing with a light bounce. Approximately 40 feet below this point, the winch and cable jumped in the rig. Immediate shutdown was initiated. Once everything was stopped, the tension gauge showed a substantial tension loss. The first step was to try to pull up out of the problem - hoping the sonde is not stuck or lost. Fult tension was regained while pulling up. We returned the sonde to surface for inspection. All was okay with no visible scars on the sonde or cable. The sonde was again sent down carefully to check the hole condition. This time a total tersion loss was encountered at the casing narrowing at $1,551.5$ feet. 
Multiple atternpts were made to try to dislodge or get by the obstruction - all unsuccessful. Attempts were made to direct the sonde and cable around all edges of the surface casing. The sampling excursion was discontinued.

Conclusions can be drawn as follows: The hole is definitely blocked at the casing narrowing at 1,551.5 feet. The hole is not straight. The outside of the sonde and cable always return greasy, indicating that it is running on the side of the casing no matter where the tripod is positioned. Thus, we always hit the same spot in the hole at the casing narrowing. Floating debris in the well made us cautious of submersed debris. Whatever debris that was below the water was dislodged and came down on top of us - fortunately, not trapping the tools in the hole. This large debris was between 1,460 feet and 1,550 feet, due to the fact that the 6 " diameter bailer ran smoothly to 1,467 feet. It also should be noted that approximately 1.5 feet due east of the well opening was a bent-over galvanized pipe $-2^{1} / 2^{\prime \prime}$ diameter by approximately $2 \frac{1}{2}$ " long. This bent galvanized pipe was always in the way on the 1986 and 1987 excursions. It was broken off and gone on the 1989 excursion (possibly down the hole?). Finally, there is no lock on the well securing it.

Suggestions: 1) video camera to bottom of hole; 2 ) remove the debris or dislodge it to the bottom of the hole; and 3) lock well. 


\section{APPENDIX C}

\section{Hole History Data for Well UE18r (Fenix and Scisson, Nevada)}

(reproduced from the best available copy) 
FENIX \& SCISSON, INC.

HOLE HISTORY DATA

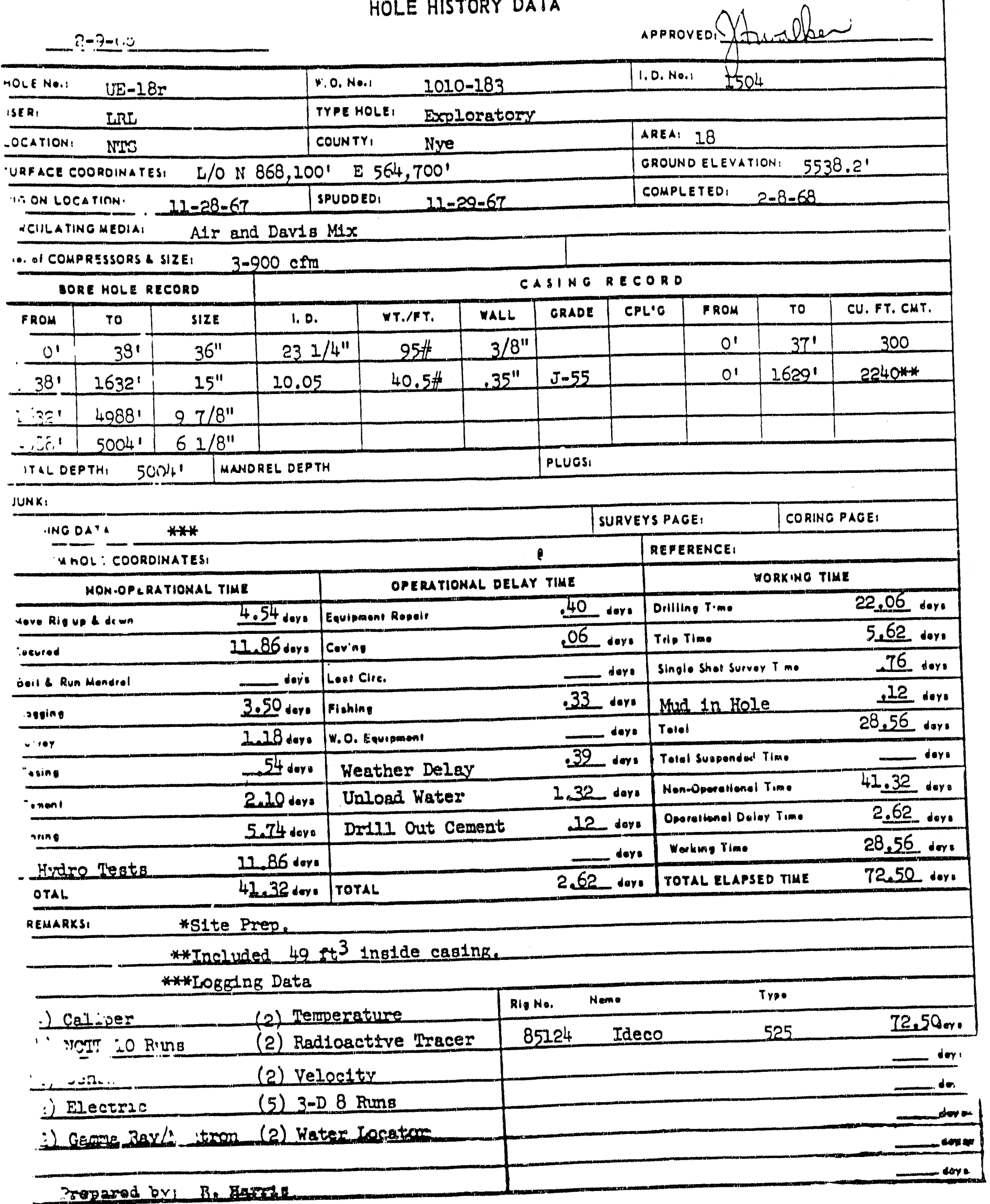




\section{UE18r \\ Hole History}

11-28-67 Moved in Ideco \#525 rig \#85124 and started to rig up.

11-29-67 Finished rigging up. Picked up $26^{\prime \prime} \times 36^{\prime \prime}$ bit assembly and started drilling. Drilled $36^{\prime \prime}$ hole from $0^{\prime}$ to $18^{\prime}$.

11-30-67 Drilled $36^{\prime \prime}$ hole from $18^{\prime}$ to $38^{\prime}$. Set $24^{\prime \prime}$ O.D. casing at $37^{\prime}$. Cemented stage $\# 1$ with $30 \mathrm{ft}^{3}$ of neat cement and $3 \% \mathrm{CaCl}_{2}$. CIP at 1700 hours. Cemented stage \#2 with $220 \mathrm{ft}^{3}$ of neat cement and $3 \% \mathrm{CaCl}_{2}$. CIP at 2030 hours.

12-1-67 Cemented stage \#3 to the surface with $50 \mathrm{ft}^{3}$ of neat cement and $3 \% \mathrm{CaCl}_{2}$. CIP at 0400 hours. Drilled out cement from $34^{\prime}$ to $37^{\prime}$. Cleaned out hole from $37^{\prime}$ to $38^{\prime}$. Drilled $15^{\prime \prime}$ hole from $38^{\prime}$ to $42^{\prime}$ using air and Davis mix as the circulating media. Hole was secured from $12-1-67$ to $12-11-67$.

12-11-67 Drilled $15^{\prime \prime}$ hole from $42^{\prime}$ to $155^{\prime}$. Ran gyro surveys.

12-12-67 Drilled $15^{\prime \prime}$ hole from $155^{\prime}$ to $409^{\prime}$.

12-13-67 Drilled $15^{\prime \prime}$ hole from $409^{\prime}$ to $508^{\prime}$. Hole was secured from 12-13-67 to $12-15-67$.

12-15-67 Cleaned out $2^{\prime}$ of fill. Made trip out and picked up core barrel. Cored $6{ }^{1} / 8^{\prime \prime}$ hole (Core \#1) from $508^{\prime}$ to $516^{\prime}$ with $6^{\prime}$ recovery. Made trip for $15^{\prime \prime}$ bit.

12-16-67 Opened $6 \frac{1}{8^{\prime \prime}}$ hole to $15^{\prime \prime}$ from $508^{\prime}$ to $516^{\prime}$. Drilled $15^{\prime \prime}$ hole from $5(1) 8^{\prime}$ to $750^{\prime}$.

12-17-67 Drilled $15^{\prime \prime}$ hole from $750^{\prime}$ to $838^{\prime}$. Made trip for core barrel. Plugged core barrel from $838^{\prime}$ to $839^{\prime}$. Pulled out and unplugged core barrel.

12-18-67 Made trip into hole. Cored $6 \frac{1}{8^{\prime \prime}}$ hole (Core \#2) from $839^{\prime}$ to $847^{\prime}$ with $8^{\prime}$ recovery. Made trip for $15^{\prime \prime}$ bit. Opened $6^{1} / 8^{\prime \prime}$ hole to $15^{\prime \prime}$ from $838^{\prime}$ to $847^{\prime}$. Drilled $15^{\prime \prime}$ hole from $847^{\prime}$ to $1022^{\prime}$.

12-19-67 Drilled $15^{\prime \prime}$ hole from $1022^{\prime}$ to $1148^{\prime}$. Made trip for core barrel. Cored $6^{1} / 8^{\prime \prime}$ hole (Core \#3) from $1148^{\prime}$ to $1156^{\prime}$ with $8^{\prime}$ izcovery. Made trip for $15^{\prime \prime}$ bit.

12-20-67 Ran in hole. Opened 61/8" hole to $15^{\prime \prime}$ from $1148^{\prime}$ to $1156^{\prime}$. Drilled $15^{\prime \prime}$ hole from $1156^{\prime}$ to $1366^{\prime}$. Made trip for core barrel. 
12-21-67 Cored $61 / 8^{\prime \prime}$ hole (Core \#4) from $1366^{\prime}$ to $1373^{\prime}$ with $6^{\prime}$ of recovery. Made trip for $15^{\prime \prime}$ bit. Opened $6^{1} / 8^{\prime \prime}$ hole to $15^{\prime \prime}$ from $1366^{\prime}$ to $1373^{\prime}$. Drilled $15^{\prime \prime}$ from $1373^{\prime}$ to $1482^{\prime}$.

12-22-67 Drilled $15^{\prime \prime}$ hole from $1482^{\prime}$ to $1615^{\prime}$. Made trip for $61 / 8^{\prime \prime}$ core barrel. Cored $6^{1} / 8^{\prime \prime}$ hole (Core \#5) from $1615^{\prime}$ to $1622^{\prime}$ with $6^{\prime}$ recovery. Made trip for $15^{\prime \prime}$ bit. Opened $6^{1} / 8^{\prime \prime}$ hole to $15^{\prime \prime}$ from $1615^{\prime}$ to $1622^{\prime}$. Drilled $15^{\prime \prime}$ hole from $1622^{\prime}$ to $1636^{\prime}$.

12-23-67 Made trip out with drilling assembly. Ran Birdwell fluid probe locating fluid level at $1423^{\prime}$. Ran Birdwell caliper log to $1629^{\prime}$. Ran Birdwell gamma ray/neutron, density, electric, and CVL logs. Ran drill pipe open ended and corrected depth to $1632^{\prime}$. Pumped 600 barrels of mud in the hole. Ran Birdwell fluid probe locating fluid level at 1008'.

12-24-67 Ran Birdwell 3-D and electric logs. Set $10^{3} / 4^{\prime \prime}$ O.D. casing at $1629^{\prime}$. Pumped 40 barrels of water ahead of cement. Cemented stage \#1 with $350 \mathrm{ft}^{3}$ of neat cement and $2 \% \mathrm{CaCl}_{2}$. CIP at 1530 hours. Hole was secured from 12-24-67 to $12-26-67$.

12-26-67 Tagged top of cement with tubing inside casing at $1552^{\prime}$. Tagged top of cement outside casing with tubing at $1126^{\prime}$. Cemented stage $\# 2$ with $500 \mathrm{ft}^{3}$ of neat cement and $2 \% \mathrm{CaCl}_{2}$. CIP at 0900 hours. Tagged top of cement at $932^{\prime}$. Cemented stage \#3 with $400 \mathrm{ft}^{3}$ of neat cement and $2 \% \mathrm{CaCl}_{2}$. CIP at 1500 hours. Tagged top of cement at $514^{\prime}$. Cemented stage $\# 4$ with $500 \mathrm{ft}^{3}$ of neat cement and $2 \% \mathrm{CaCl}_{2}$. CIP at 2100 hours. Located top of cement with NCTL $\log$ at $362^{\prime}$. Tagged top of cement with tubing at $356^{\prime}$.

12-27-67 Cemented stage \#5 with $180 \mathrm{ft}^{3}$ of neat cement and $2 \% \mathrm{CaCl}_{2}$. CIP at ()130) hours. Tagged top of cement at $202^{\prime}$. Cemented stage \#6 to the surface with $310 \mathrm{ft}^{3}$ of neat cement and $2 \% \mathrm{CaCl}_{2}$. CIP at (0630 hours. Total cement used was $2240 \mathrm{ft}^{3}$. Calculated annular volume was $1357 \mathrm{ft}^{3}$. Ran Sperry-Sun Multishot Gyroscopic survey in and out on $25^{\prime}$ stations. Lay down $65 / 8^{\prime \prime}$ drill pipe. Reran gyro survey.

12-28-67 Finished running gyro survey. Made up drilling assembly which consisted of $9^{7} / 8^{\prime \prime}$ bi, Float sub, $7^{7} / 8^{\prime \prime}$ O.D. hammer, sub, Monel DC, Reamer, Monel DC, Steel DC (6) sub, and $41 / 2^{\prime \prime}$ O.D. drill pipe. Made trip in hole. Tagged top of cement inside casing at $1546^{\prime}$. Drilled out cement and plug from 1546'to $1629^{\prime}$. Cleaned out hole from $1629^{\prime}$ to $1632^{\prime}$. Drilled $9^{7} / 8^{\prime \prime}$ hole from $1632^{\prime}$ to $1819^{\prime}$. 
12-29-67 Drilled $97 / 8^{\prime \prime}$ hole from $1819^{\prime}$ to $1922^{\prime}$. Made trip for core barrel. Cored $61 / 8^{\prime \prime}$ hole (Core \#6) from $1922^{\prime}$ to $1931^{\prime}$ with $9^{\prime}$ recovery. Made trip for $97 / 8^{\prime \prime}$ bit. Opened $6^{1} / 8^{\prime \prime}$ hole to $9^{7} / 8^{\prime \prime}$ from $1922^{\prime}$ to $1931^{\prime}$. Drilled $9^{7} / 8^{\prime \prime}$ hole from $1931^{\prime}$ to $1998^{\prime}$.

12-30-67 Drilled $97 / 8^{\prime \prime}$ hole from $1998^{\prime}$ to $2105^{\prime}$.

12-31-67 Drilled $9^{7} / 8^{\prime \prime}$ hole from $2105^{\prime}$ to $2228^{\prime}$. Hole was secured from $12-31-67$ to $1-2-68$.

1-2-68 Made trip for core barrel. Cored $6^{1} / 8^{\prime \prime}$ hole (Core \#7) from $2228^{\prime}$ to $2234^{\prime}$ with $6^{\prime}$ recovery. Made trip for $9^{7} / 8^{\prime \prime}$ bit. Opened $61 / 8^{\prime \prime}$ hole to $97 / 8^{\prime \prime}$ from $2228^{\prime}$ to $2234^{\prime}$. Drilled $9^{7} / 8^{\prime \prime}$ hole from $2234^{\prime}$ to $2275^{\prime}$.

1-3-68 Drilled $97 / 8^{\prime \prime}$ hole from $2275^{\prime}$ to $2384^{\prime}$.

1-4-68 Drilled $97 / 8^{\prime \prime}$ hole from $2384^{\prime}$ to $2479^{\prime}$.

1-5-68 Drilled $97 / 8^{\prime \prime}$ hole from $2479^{\prime}$ to $2594^{\prime}$.

1-6-68 Drilled $97 / 8^{\prime \prime}$ hole from $2594^{\prime}$ to $2721^{\prime}$. Twisted off drill column. Fish in the hole consisted of four steel drill collars, two monel collars, air hammer, three subs, and $9^{7} / 8^{\prime \prime}$ bit. Fish was $179^{\prime}$ long with top at $2542^{\prime}$.

1-7-68 Made up fishing tools and ran in hole. Latched on to and recovered fish from the hole. Made up $9^{7} / 8^{\prime \prime}$ drill assembly. Drilled $9^{7} / 8^{\prime \prime}$ hole from $2721^{\prime}$ to $2752^{\prime}$.

1-8-68 Drilled $97 / 8^{\prime \prime}$ hole from $2752^{\prime}$ to $2811^{\prime}$. Made trip for core barrel. Cored $61 / 8^{\prime \prime}$ hole (Core \#8) from $2811^{\prime}$ to $2815^{\prime}$ with $4^{\prime}$ recovery.

1-9-68 Made trip for $97 / 8^{\prime \prime}$ bit. Opened $61 / 8^{\prime \prime}$ hole to $97 / 8^{\prime \prime}$ from $2811^{\prime}$ to $2815^{\prime}$. Drilled $9^{7} / 8^{\prime \prime}$ hole from $2815^{\prime}$ to $2898^{\prime}$.

1-10-68 Drilled $97 / 8^{\prime \prime}$ hole from $2898^{\prime}$ to $3023^{\prime}$.

1-11-68 Drilled $97 / 8^{\prime \prime}$ hole from $3023^{\prime}$ to $3096^{\prime}$. Made trip for core barrel. Ran Birdwell caliper log to 3096 ${ }^{\prime}$. Cored $6^{1} / 8^{\prime \prime}$ hole (Core \#4) from 3096 to $3106^{\prime}$ with $10^{\prime}$ recovery. Ran Birdwell temperature survey.

1-12-68 Made trip for $97 / 8^{\prime \prime}$ bit. Opened $61 / 8^{\prime \prime}$ hole to $9^{7} / 8^{\prime \prime}$ from $3096^{\prime}$ to $3106^{\prime}$. Drilled $9^{7} / 8^{\prime \prime}$ hole from $3106^{\prime}$ to $3342^{\prime}$. 
1-13-68 Drilled $97 / 8^{\prime \prime}$ hole from $3342^{\prime}$ to $3604^{\prime}$. Made trip for core barrel. Cored $61 / 8^{\prime \prime}$ hole (Core \#10) from $3604^{\prime}$ to $3610^{\prime}$ with $6^{\prime}$ recovery.

1-14-68 Made trip for $97 / 8^{\prime \prime}$ bit. Opened $61 / 8^{\prime \prime}$ hole to $97 / 8^{\prime \prime}$ from $36\left(14^{\prime}\right.$ to $3610^{\prime}$. Drilled $9^{7} / 8^{\prime \prime}$ hole from $3610^{\prime}$ to $3740^{\prime}$.

1-15-68 Drilled $9^{7} / 8^{\prime \prime}$ hole from $3740^{\prime}$ to $3899^{\prime}$. Made trip for core barrel. Cored $61 / 8^{\prime \prime}$ hole (Core \#11) from $3899^{\prime}$ to $3907^{\prime}$ with $8^{\prime}$ recovery. Made trip for $9^{7} / 8^{\prime \prime}$ bit.

1-16-68 Opened $6^{1} / 8^{\prime \prime}$ hole to $9^{7} / 8^{\prime \prime}$ from $3899^{\prime}$ to $3907^{\prime}$. Drilled $97 / 8^{\prime \prime}$ hole from $3907^{\prime}$ to $4094^{\prime}$.

1-17-68 Drilled $97 / 8^{\prime \prime}$ hole from $4094^{\prime}$ to $4212^{\prime}$. Made trip for core barrel. Cored $61 / 8^{\prime \prime}$ hole (Core \#12) from $4212^{\prime}$ to $4217^{\prime}$ with $4^{\prime}$ recovery. Made trip for $9^{7} / 8^{\prime \prime}$ bit.

1-18-68 Opened $6^{1} / 8^{\prime \prime}$ hole to $9^{7} / 8^{\prime \prime}$ from $4212^{\prime}$ to $4217^{\prime}$. Drilled $9^{7} / 8^{\prime \prime}$ hole from $4217^{\prime}$ to $4402^{\prime}$.

1-19-68 Ran Birdwell caliper log to $4398^{\prime}$.

1-20-68 Drilled $9^{7} / 8^{\prime \prime}$ hole from $4402^{\prime}$ to $4588^{\prime}$. Made trip for core barrel. Cored $6^{1} / 8^{\prime \prime}$ hole (Core \#13) from $4588^{\prime}$ to $4600^{\prime}$ with $12^{\prime}$ recovery.

1-21-68 Made trip for $9^{7} / 8^{\prime \prime}$ bit. Opened $6 \frac{1}{8^{\prime \prime}}$ hole to $9^{7} / 8^{\prime \prime}$ from $4588^{\prime}$ to $4600^{\prime}$. Drilled $9^{7} / 8^{\prime \prime}$ hole from $4600^{\prime}$ to $4714^{\prime}$.

1-22-68 Drilled $9^{7} / 8^{\prime \prime}$ hole from $4714^{\prime}$ to $4867^{\prime}$. Made trip for core barrel. Cored $61 / 8^{\prime \prime}$ hole (Core \#14) from $4867^{\prime}$ to $4879^{\prime}$ with $12^{\prime}$ recovery. Made trip out for $97 / 8$ bit.

1-23-68 Opened $6 \frac{1}{{ }^{\prime \prime}}$ " hole to $9^{7} / 8^{\prime \prime}$ from $4867^{\prime}$ to $4879^{\prime}$. Drilled $97 / 8^{\prime \prime}$ hole from $4879^{\prime}$ to $4988^{\prime}$ Made trip for core barrel. Cored $6{ }^{1} / 8^{\prime \prime}$ hole (Core \#15) from $4988^{\prime}$ to $4992^{\prime}$.

1-24-68 Cored $6 \frac{1}{1} 8^{\prime \prime}$ hole from $4992^{\prime}$ to $5004^{\prime}$ with $16^{\prime}$ recovery. Made trip out of hole. Ran Birdwell gamma ray/neutron, density, electric, CVL, and 3-D logs.

1-25-68 Ran Birdwell temperature study and Trace Ejector log. Prepared to run Reda pump in hole.

1-26-68 Ran Reda pump on $278^{\prime \prime}$ tubing to $1736^{\prime}$. Started pumping water out of hole.

1-27-68 Pumped the well. 
1-28-68 Pumped the well. Ran Birdwell Trace Ejector log.

1-29-68 Ran USGS fluid probe. Pulled Reda pump. Ran Lynes straddle packers on $27 / 8$ "tubing.

1-30-68 Attempted to fill tubing with water. Tubing was found to be leaking. Made trip out of hole to check packers. Ran packers back in hole and performed hydrologic tests. Ran USGS fluid probe. Swabbed $2^{7} / 8^{\prime \prime}$ tubing.

1-31-68 Swabbed $27 / 8$ tubing. Performed hydrologic tests. Ran and reran USGS fluid probe locating fluid level at $1385^{\prime}$.

2-1-68 Continued performing hydrologic tests and running fluid probes.

2-2-68 Continued hydrologic testing.

2-3-68 Continued hydrologic tests.

2-4-68 Continued hydrologic tests.

2-5-68 Finished hydrologic tests. Ran Birdwell temperature survey and Input Profile $\log$.

2-6-68 Ran Birdwell electric log. Started to run Sperry-Sun gyro survey.

2-7-68 Completed running Sperry-Sun gyro survey in and out on $30^{\prime}$ stations to $4981^{\prime}$. Rigged down.

2-8-68 Moved off. Hole was completed 2-8-68. 
TABLE C-1. LIST OF AVAILABLE ELECTRIC WELL LOGS FOR WELL UE18r.

Date

Site Name (MDY)

UE18r

$12 / 23 / 6$

$12 / 23 / 67$

$12 / 23 / 67$

$12 / 23 / 67$

$12 / 23 / 67$

$12 / 23 / 67$

$12 / 24 / 67$

$12 / 24 / 67$

$12 / 24 / 67$

$12 / 26 / 67$

$12 / 26 / 67$

$12 / 26 / 67$

$12 / 27 / 67$

$01 / 11 / 68$

$01 / 11 / 68$

$01 / 19 / 68$

$01 / 24 / 68$

$01 / 24 / 68$

$01 / 24 / 68$

$01 / 24 / 68$

$01 / 24 / 68$

$01 / 25 / 68$

$01 / 25 / 68$

$01 / 25 / 68$

$02 / 06 / 68$

$11 / 11 / 77$

$06 / 11 / 78$

$06 / 11 / 78$

$06 / 12 / 78$

$06 / 12 / 78$

$06 / 12 / 78$

$10 / 25 / 90$
Type 3-D velocity

caliper

density

nuclear

velocity

water locator

3-D velocity

clectric (2)

$3-D$ velocity

nuclear cement top locator

nuclear cement top locator

nuclear cement top locator

nuclear cement top locator

caliper

tempera ure

caliper

3-D velocity $12^{\prime}(2)$

caliper

density (2)

nuclear (2)

velocity

3-D velocity (2)

radioactive tracer

temperature (2)

electric

caliper

density borehole compensate

density dual proximity

$3-D$ velocity $12^{\prime}$

$3-\mathrm{D}$ velocity $6^{\prime}$

electric

high resolution temperature
Drill Depth Interval Logged

(ft)

(ft)

\begin{tabular}{rr}
1636.00 & $1000-1623$ \\
1636.00 & $0-1626$ \\
1636.00 & $0-1628$ \\
1636.00 & $0-1616$ \\
1636.00 & $1010-1623$ \\
1636.00 & $1300-1431$ \\
1636.00 & $1100-1619$ \\
1636.00 & $1100-1627$ \\
1636.00 & $1160-1620$ \\
1632.00 & $342-494$ \\
1632.00 & $842-1000$ \\
1632.00 & $992-1552$ \\
1632.00 & $0-1550$ \\
3096.00 & $1600-3094$ \\
3096.00 & $0-3104$ \\
4402.00 & $1550-4395$ \\
5004.00 & $1800-4980$ \\
5004.00 & $1500-4988$ \\
5004.00 & $1600-4985$ \\
5004.00 & $1600-4975$ \\
5004.00 & $2000-4986$ \\
5004.00 & $1800-4983$ \\
5004.00 & $2050-3532$ \\
5004.00 & $1600-4992$ \\
5004.00 & $1620-4986$ \\
5004.00 & $0-4990$ \\
5004.00 & $1600-4992$ \\
5004.00 & $1600-4993$ \\
5004.00 & $1600-4983$ \\
5004.00 & $1600-4987$ \\
5004.00 & $1650-4987$ \\
5004.00 & $1351-2504$ \\
\hline
\end{tabular}




\section{Deviation Surveys}

\begin{tabular}{|c|c|}
\hline Depth & Deviation \\
\hline $.50^{\prime}$ & $0^{\circ} 7^{\prime}\left(\mathrm{S} 62^{\circ} 52^{\prime} \mathrm{E}\right)$ \\
\hline $300^{\prime}$ & $\left(0^{\circ} 4^{\prime}\left(\mathrm{S} 44^{\circ} 40^{\prime} \mathrm{E}\right)\right.$ \\
\hline $450^{\prime}$ & $\left(0^{\circ} 5^{\prime}\left(\mathrm{S} 50^{\circ} 02^{\prime} \mathrm{E}\right)\right.$ \\
\hline $600^{\prime}$ & 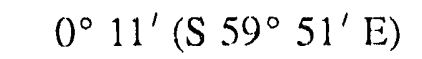 \\
\hline $740^{\prime}$ & $0^{\circ} 13^{\prime}\left(\mathrm{S} 00^{\circ} 10^{\prime} \mathrm{W}\right)$ \\
\hline $890^{\prime}$ & $0^{\circ} 12^{\prime}\left(\mathrm{S} 55^{\circ} 46^{\prime} \mathrm{W}\right)$ \\
\hline $1040^{\prime}$ & $0^{\circ} 15^{\prime}\left(\mathrm{S} 76^{\circ} 29^{\prime} \mathrm{W}\right)$ \\
\hline $1190^{\prime}$ & $0^{\circ} 10^{\prime}\left(\mathrm{S} 68^{\circ} 39^{\prime} \mathrm{W}\right)$ \\
\hline $1330^{\prime}$ & $0^{\circ} 17^{\prime}\left(\mathrm{S} 46^{\circ} 13^{\prime} \mathrm{W}\right)$ \\
\hline $1480^{\prime}$ & $0^{\circ} 18^{\prime}\left(\mathrm{S} 41^{\circ} 13^{\prime} \mathrm{W}\right)$ \\
\hline $1630^{\prime}$ & $0^{\circ} 33^{\prime}\left(\mathrm{S} 24^{\circ} 31^{\prime} \mathrm{W}\right)$ \\
\hline $1780^{\prime}$ & $0^{\circ} 40^{\prime}\left(\mathrm{S} 22^{\circ} 38^{\prime} \mathrm{W}\right)$ \\
\hline $1920^{\prime}$ & $0^{\circ} 40^{\prime}\left(\mathrm{S} 15^{\circ} 58^{\prime} \mathrm{W}\right)$ \\
\hline $2070^{\prime}$ & $0^{\circ} 36^{\prime}\left(\mathrm{S} 21^{\circ} 39^{\prime} \mathrm{W}\right)$ \\
\hline $2220^{\prime}$ & $0^{\circ} 42^{\prime}\left(\mathrm{S} 19^{\circ} 13^{\prime} \mathrm{W}\right)$ \\
\hline $2370^{\prime}$ & $1^{\circ} 00^{\prime}\left(\mathrm{S} 28^{\circ} 29^{\prime} \mathrm{W}\right)$ \\
\hline $2520^{\prime}$ & $1^{\circ} 00^{\prime}\left(\mathrm{S} 27^{\circ} 40^{\prime} \mathrm{W}\right)$ \\
\hline $2670^{\prime}$ & $0^{\circ} 50^{\prime}\left(\mathrm{S} 00^{\circ} 51^{\prime} \mathrm{W}\right)$ \\
\hline $2820^{\prime}$ & $0^{\circ} 45^{\prime}\left(\mathrm{S} 03^{\circ} 19^{\prime} \mathrm{E}\right)$ \\
\hline $2970^{\prime}$ & $0^{\circ} 32^{\prime}\left(\mathrm{S}\left(04^{\circ} 35^{\prime} \mathrm{E}\right)\right.$ \\
\hline $3120^{\prime}$ & $0^{\circ} 43^{\prime}\left(\mathrm{S} 17^{\circ} 46^{\prime} \mathrm{W}\right)$ \\
\hline $3270^{\prime}$ & $0^{\circ} \quad 58^{\prime}\left(\mathrm{S} 13^{\circ} 33^{\prime} \mathrm{W}\right)$ \\
\hline $3420^{\prime}$ & $1^{\circ}() 4^{\prime}\left(\mathrm{S} 12^{\circ} 44^{\prime} \mathrm{W}\right)$ \\
\hline $3570^{\prime}$ & $0^{\circ} 51^{\prime}\left(\mathrm{S} 00^{\circ} 10^{\prime} \mathrm{W}\right)$ \\
\hline $3720^{\prime}$ & $0^{\circ} 54^{\prime}\left(\mathrm{S} 04^{\circ} 14^{\prime} \mathrm{E}\right)$ \\
\hline $3870^{\prime}$ & $1^{\circ} 11^{\prime}\left(\mathrm{S} 14^{\circ} 14^{\prime} \mathrm{E}\right)$ \\
\hline $4020^{\prime}$ & $1^{\circ} 30^{\prime}\left(\mathrm{S} 35^{\circ} 57^{\prime} \mathrm{E}\right)$ \\
\hline $4170^{\prime}$ & $0^{\circ} 58^{\prime}\left(\mathrm{S} 30^{\circ}\left(09^{\prime} \mathrm{E}\right)\right.$ \\
\hline $4320^{\prime}$ & $0^{\circ} 28^{\prime}\left(\mathrm{S} 18^{\circ} 11^{\prime} \mathrm{E}\right)$ \\
\hline 4490$)^{\prime}$ & $0^{\circ} 25^{\prime}\left(\mathrm{S} 67^{\circ} 40^{\prime} \mathrm{W}\right)$ \\
\hline $4650^{\prime}$ & $0^{\circ} 38^{\prime}\left(\mathrm{S} 63^{\circ} 18^{\prime} \mathrm{W}\right)$ \\
\hline $4880^{\prime}$ & $0^{\circ} 47^{\prime}\left(\mathrm{W} 89^{\circ} 55^{\prime} \mathrm{W}\right)$ \\
\hline $4950^{\prime}$ & $0^{\circ} 50^{\prime}\left(\mathrm{W} 56^{\circ}\left(12^{\prime} \mathrm{W}\right)\right.$ \\
\hline $4981^{\prime}$ & $0^{\circ} 53^{\prime}\left(\mathrm{W} 65^{\circ} 10^{\prime} \mathrm{W}\right)$ \\
\hline
\end{tabular}




\section{Sperry-Sun Multishot Gyroscopic Survey}

\begin{tabular}{|c|c|c|c|c|c|}
\hline Date & MD & TVD & $\frac{\text { Horizontal }}{\text { Displacement }}$ & Reference & Run \\
\hline $12-27-67$ & $1540^{\prime}$ & $1539.98^{\prime}$ & $2.59^{\prime}\left(\mathrm{S} 38^{\circ} 20^{\prime} \mathrm{W}\right)$ & $151-S U 3-304$ & In \\
\hline $12-27-67$ & $1540^{\prime}$ & $1539.98^{\prime}$ & $2.51^{\prime}\left(\mathrm{S} 36^{\circ} 59^{\prime} \mathrm{W}\right)$ & $51-S U 3-304$ & Out \\
\hline$(12-0) 6-68$ & $30000^{\prime}$ & $2999.86^{\prime}$ & $21.91^{\prime}\left(\mathrm{S} 17^{\circ} 31^{\prime} \mathrm{W}\right)$ & $151-S U 3-331$ & In \\
\hline (1) $2-06-68$ & $30000^{\prime}$ & $2999.86^{\prime}$ & $21.71^{\prime}\left(\mathrm{S} 21^{\circ} 07^{\prime} \mathrm{W}\right)$ & $151-$ SU3--331 & Out \\
\hline$(1)-06-68$ & $4981^{\prime}$ & $4980.61^{\prime}$ & $44.94^{\prime}\left(\mathrm{S} 13^{\circ} 12^{\prime} \mathrm{W}\right)$ & $151-S U 3-331$ & In \\
\hline ()2-1)6-68 & $4981^{\prime}$ & $4980.61^{\prime}$ & $44.56^{\prime}\left(\mathrm{S} 12^{\circ} 06^{\prime} \mathrm{W}\right)$ & $151-$ SU3 -331 & Out \\
\hline
\end{tabular}

\section{Core Data}

\begin{tabular}{c} 
Run \# \\
\hline 1 \\
2 \\
3 \\
4 \\
5 \\
6 \\
7 \\
8 \\
9 \\
10 \\
11 \\
12 \\
13 \\
14 \\
15
\end{tabular}

\section{Interval}

$0508^{\prime}-0516^{\prime}$

$0839^{\prime}-0847^{\prime}$

$1148^{\prime}-1156^{\prime}$

$1366^{\prime}-1373^{\prime}$

$1615^{\prime}-1622^{\prime}$

$1922^{\prime}-1931^{\prime}$

$2228^{\prime}-2234^{\prime}$

$2611^{\prime}-2615^{\prime}$

$3096^{\prime}-3106^{\prime}$

$3604^{\prime} \ldots 3610^{\prime}$

$3899^{\prime}-3907^{\prime}$

$4212^{\prime}-4217^{\prime}$

$\left.4588^{\prime}-4600\right)^{\prime}$

$4867^{\prime}-4879^{\prime}$

$4988^{\prime}-5004^{\prime}$

\section{Recovery}

$8^{\prime}$

$8^{\prime}$

$8^{\prime}$

$6^{\prime}$

$6^{\prime}$

$9^{\prime}$

6

$4^{\prime}$

$10^{\prime}$

$6^{\prime}$

$8^{\prime}$

$4^{\prime}$

$12^{\prime}$

$12^{\prime}$

$16^{\prime}$ 


\section{Review of Hole Conditions}

Spudded: $11-29-67$

$36^{\prime \prime}$ hole to $38^{\prime}$

$15^{\prime \prime}$ hole to $1632^{\prime}$

Cemented annulus to the

surface with 2191 (plus $49 \mathrm{ft}^{3}$

inside casing of cement) slurry.

$97 / 8^{\prime \prime}$ hole to $4988^{\prime}$

$61 / 8^{\prime \prime}$ hole to $5004^{\prime}$
Completed: 2-8-68

Set 24" O.D. casing at $37^{\prime}$. Cemented annulus to $81 / 2$ below surface with 3()() $\mathrm{ft}^{3}$ of cement slurry.

Set $10^{3 / 4^{\prime \prime}}$ O.D. casing at $1629^{\prime}$.

I. This hole was drilled using air and Davis mix as the circulating media. A caliper log run to $1626^{\prime}$ indicated very little erosion.

II. Cementing of $10^{3} / 4^{\prime \prime}$ O.D. casing (mud in hole).

\section{Stage \#}

1

2

3

4

5

6
Interval

$1629^{\prime}-1126^{\prime}$

$1126^{\prime}-0932^{\prime}$

$0932^{\prime}-0514^{\prime}$

()514' - $0362^{\prime}$

(0)362'-0202'

$0202^{\prime}-0^{\prime}$

\section{Actual Cement Used}

$350 \mathrm{ft}^{3}$

$500 \mathrm{ft}^{3}$

$400 \mathrm{ft}^{3}$

$500 \mathrm{ft}^{3}$

$180 \mathrm{ft}^{3}$

$\frac{310 \mathrm{ft}^{3}}{2240 \mathrm{ft}^{3}}$
Cal. Ana. Vol.

$379 \mathrm{ft}^{3}$

$254 \mathrm{ft}^{3}$

$245 \mathrm{ft}^{3}$

$144 \mathrm{ft}^{3}$

$182 \mathrm{ft}^{3}$

$\frac{153 \mathrm{ft}^{3}}{1357 \mathrm{ft}^{3}}$ 
$U \pi-18 r$

CEMENTING GRAPH

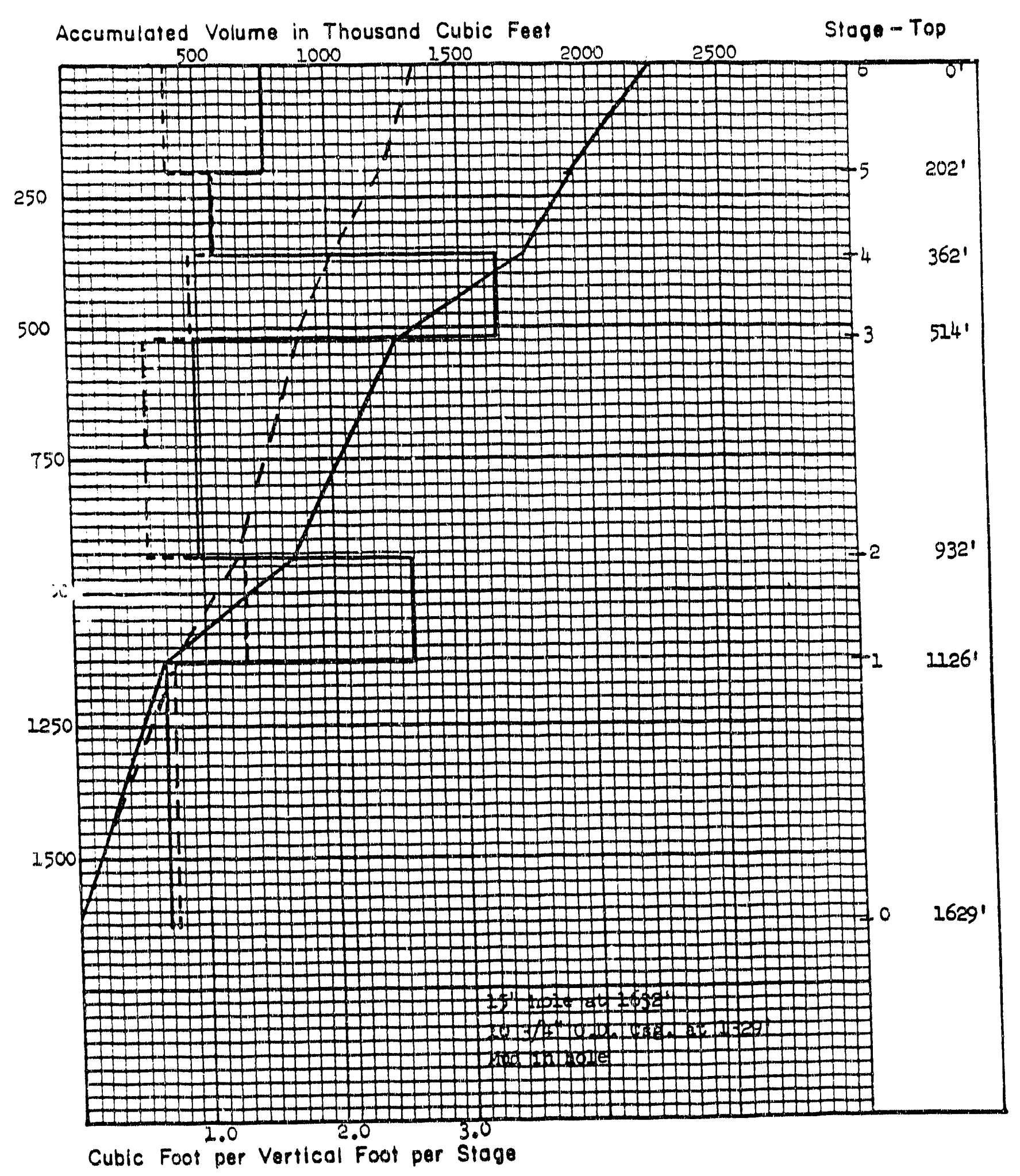

Cola Ann. Vol.

Cemant Ueed

Total Cement Used = $2240 \mathrm{rt}^{3}$

Total Calculoted $=\frac{2357 \mathrm{tt}^{3}}{+883 \mathrm{H}}$
Difference 
03-28-72 Unable to pull USGS downhole package using Birdweli equipment.

09-11-75 Prior to 09-11-75 packer and USGS instruments were retrieved using USGS equipment.

11-11-75 Ran Birdwell caliper log to 1990'.

06-11-78 Ran Birawell bore hole compensated and dual proximity aensity logs to $4994^{\prime}$. Ran fluid density log, fluid level at 1370'.

$06-12-78$

Ran Birdwell 3-D logs to 4993'. Ran electric log to $4988^{\prime}$.

06-23-78 Started running Birdwell vibroseis survey.

$\therefore-24-78$ Completed vibroseis survey. Set Gearnart Owens 9-5/2" wire line bridoe piug in the hole at $2505^{\prime}$. Dumped 2.55 gallons of sana and 2.55 gallons of Cal-Seal on plug. 


\title{
APPENDIX D
}

\author{
Hole History Data for UEGe \\ (Fenix and Scisson, Nevada)
}


FENIX \& SCISSON, INC.

HOLE HISTORY DATA

DATE, 9-27-74 14

NOLENO.1 UE-6e

W. 0. No.1 1052-334 B

APPROVED

$-4+4+2-2$ -

TYPE HOLE: EXD LOCTEOTY

COUNTY, NYe

AREA, 6

LOCATION NTS

E 688.200'

SURFACE COORDINATES: $3 / 0 \quad 814,000^{\prime}$

GROUND ELEYATION: $3935.6^{\prime}$

PAD ELEYATION,

TOP CASINC ELEYATION

RIG ON LOCATIONI

SPUDDED, $2-27-73$

COMPLETED 12-3-73

CIRCULATING MEOLA, ALt EOam $120^{\prime}$ to $1977^{\prime}$ and $2886^{\prime}$ to $4113^{\prime}$, conventional * $\%$

MAIN RIS \& CONTRACTOR IUECO \#525. REECO

NO. OF COMPRESSORS \& CAPACITY, $3-1000 \mathrm{cFm}$

\section{\begin{tabular}{|l|l}
\hline BORE HOLE RECORD & CASING RECORO
\end{tabular}}

\begin{tabular}{|c|c|c|c|c|c|c|c|c|c|c|}
\hline$F R O M$ & TO & SIZE & 1.D. & WT./FT. & WALL & GRADE & CPL'O. & FROM & TO & CU, FT, CHT. \\
\hline $0^{\prime}$ & $120^{\prime}$ & $36^{\prime \prime}$ & $19.50^{\prime \prime}$ & 52.73 k & $z_{11}$ & $B W$ & & $0^{\prime}$ & $110^{\prime \prime}$ & 760 \\
\hline $120^{\prime}$ & $2886^{\prime}$ & $122^{\prime \prime}$ & $8.921^{\prime \prime}$ & 36.00 非 & & $J-55$ & & $0^{\prime}$ & $2090^{\prime}$ & 645 \\
\hline $2886^{\prime}$ & $4209^{\prime}$ & $8-3 / 4^{\prime \prime}$ & & & & & & & & \\
\hline & & & & & & & & & & \\
\hline & & & & & & & & & & \\
\hline & & & & & & & & & & \\
\hline
\end{tabular}

TOTAL OEPTH $4209^{\prime} \mathrm{CL}$

CU. FT. CHT, TOTAL IN PLUGS, ETC:

SURVEYS PAGE: CORING PAGE

LogGING oATA, Caliper (6), NCTL (2-3 runs), Densitv (3), hater Locator (3-4 runs) *:

BOTTOM HOLE COORDIHATES,

REFEREHCE:

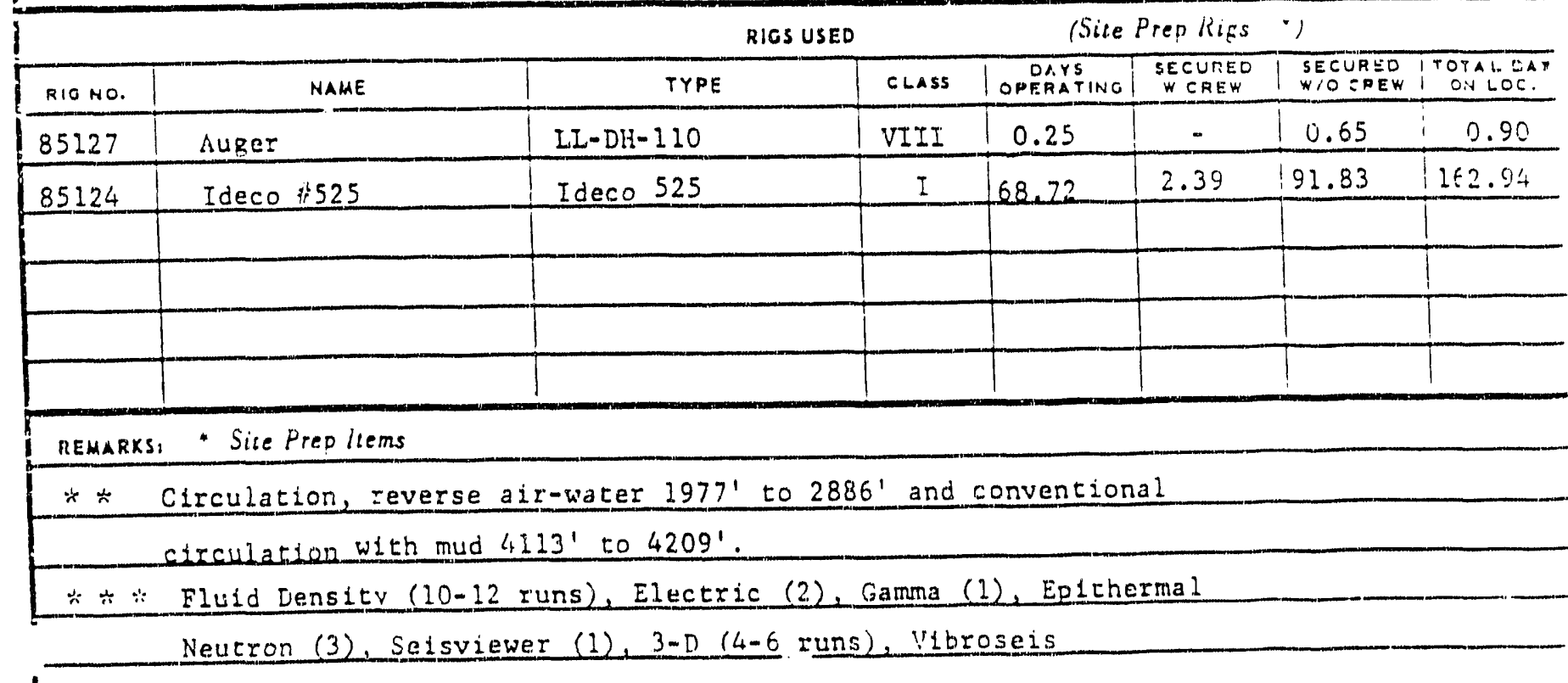

PREPLT:=0 QY

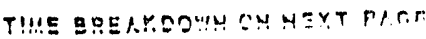


TIE-6e

TIME BREAKDOWN

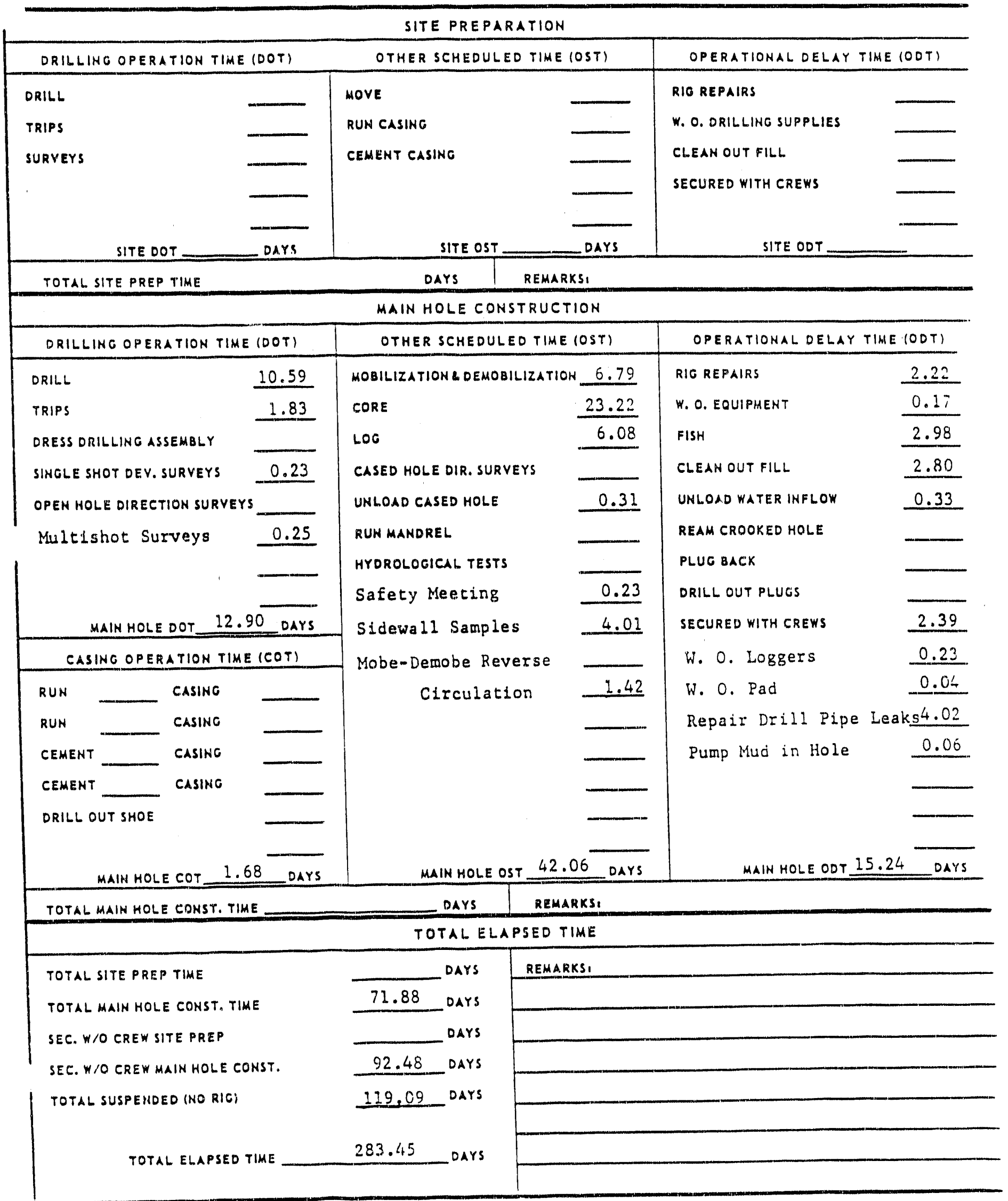


2-27-73 Moved in Auger rig 非85127 and drilled $36^{\prime \prime}$ hole from $0^{\prime}$ to $87^{\prime}$.

2-28-73 Drilled 36" hole from $87^{\prime}$ to $120^{\prime}$ and moved out rig. Ran and welded $20^{\prime \prime}$ O.D., 1/4" wall casing with a crane. Set at $110^{\prime}$ G.L. Cemented annulus as forlows:

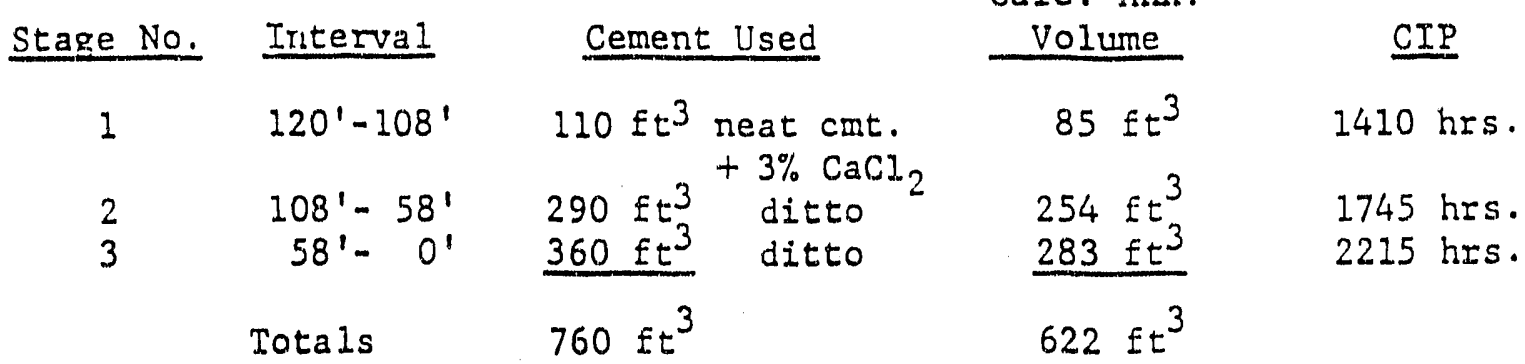

3-19-93 Hole suspended from 2-28-73 to 3-19-73. Moved in Ideco $\#_{1} 85124$ and started rigging up.

3-20-73 Continued rigging up.

3-21-73 Completed rigging up. Drilled out cement from $110^{\prime}$ to $120^{\prime}$ and $12-1 / 4^{\prime \prime}$ hole from $120^{\prime}$ to $133^{\prime}$. Blew hole dry. Cut core 非 from $133^{\prime}$ to $147^{\prime}$, recovered 6-1/2'. Reamed core hole to $147^{\prime}$ with 12-1/4" bit. Drilled and reamed using conventional circulation with air foam. Cored with rubber sleeve core barrel, 7-1/2" core bit, circulated with air.

3-22-73 Drilled 12-1/4" hole from 147' to 151:. Blew hole with air and bailed. Cut core 非 from $151^{\prime}$ to $167^{\prime}$, recovered $4-1 / 2^{\prime}$. Reamed core hole to $167^{\prime}$ with 12-1/4". Blew hole with air and bailed, cirm culated out $2^{\prime}$ of formation to $169^{\prime}$. Cut core $\$ 3$ from $169^{\prime}$ to $187^{\prime}$, recovered $13^{\prime}$. Cleaned out $12^{\prime}$ of fill and reamed core hole to $187^{\prime}$ with 12-1/4" bit. Cut core $\$ 4$ from $187^{\prime}$ to $204^{\prime}$, recovered $66^{\prime}$. Seured rig at 2400 hours. Reamed using conventional circulation with air foam. Cored with rubber slceve core barrel, $7-1 / 2 "$ core bit, circulated with air.

3-23-73 Rig secured to 1600 hours. Cleaned out $5^{\prime}$ of fill and reamed core hole to $204^{\prime}$ with $12-1 / 4^{\prime \prime}$ bit. Blew hole with air and bailed. Circulated out $4^{\prime}$ of formation and cut core 非 from $208^{\prime}$ to $224^{\prime}$, recovered $8-1 / 2^{\prime}$. Reamed core hole to $24^{\prime}$ and drilled 12-1/4" hole to $230^{\prime}$. Reamed and drilled using conventional circulation with air foam. Cored with rubber sleeve core barrel, $7 \cdot 1 / 2 "$ core bit, circulated with air.

3-24-73 Blew hole with aiI and bailed. Cut core 非 from 230' to 248', recovered $12-1 / 2^{\prime}$. Cleaned out $10^{\prime}$ of fill and reamed core hole to $248^{\prime}$ with 12-1/4" bit. Blew hole with air. Cut core $\left.\right|^{\prime \prime} 7$ from $248^{\prime}$ to $267^{\prime}$ rem covered 12'. Cleaned out $12^{\prime}$ of fill and reamed core hole to $267^{\prime}$ with 12-1/4" bit. Blew hole with air and bailed. Circulated out 7 ' of formation to $274^{\prime}$ and cut core 非 from $274^{\prime}$ to $286^{\prime}$, recovered 5.1'. Roamed core hole to $286^{\prime}$ with 12-1/4" bit. Blew hole with air and bailed. Reamed using conventional circulation with air-foam. cored vith rubbcr sleeve core barrel, $7-1 / 2 "$ core bit, circulated witin aiz. 
UE- $6 e$

Hole History

Page 2

$3-25-73$

Circulated out $4^{\prime}$ of formation to $290^{\prime}$, cut core 非 from $290^{\prime}$ to $313^{\prime}$ recovered 12'. Reamed core hole to $313^{\prime}$ with 12-1/4" bit. Blew hole with air and bailed. Circulated out $1^{\prime}$ of formation to $314^{\prime}$, cut core 非10 from $314^{\prime}$ to $334^{\prime}$, no recovery. Cleaned out $22^{\prime}$ of fill and reamed core hole to $334^{\prime}$ with 12-1/4" bit. Blew hole with air and

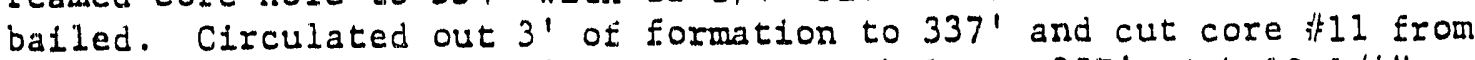
$337^{\prime}$ to $357^{\prime}$, recovered ' $^{\prime}$. Reamed core hole to $357^{\prime}$ with $12-1 / 4^{\prime \prime}$ bit. Blew hole with air and bailed.

3-26-73 Cut core 非12 from $357^{\prime}$ to $376^{\prime}$, recovered 15-1/2'. Cleaned out $13^{\prime}$ of fill and reamed core hole to $376^{\prime}$ with 12-1/4" bit. Blew hole with air and bailed. Circulated out $2^{\prime}$ of formation and cut core

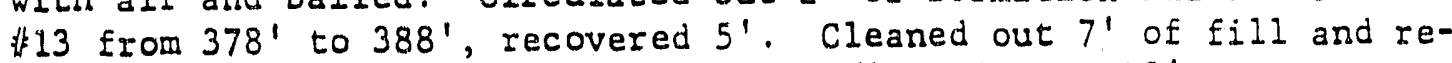
amed core hole to $388^{\prime}$ and drilled 12-1/4" hole to 398'. Cut core 非 14 from 398' to 421', recovered 16-1/2'. Dropped $12^{\prime \prime}$ crescent wrench in the hole. Reamed and drilled using conventional circulation with air foam. Cored with rubber sleeve core barrel, 7-1/2" core bit, circulated with air.

$3-27-73$

$3-28-73$

Reamed core hole to $421^{\prime}$ and drilled 12-1/4" hole from 421' to $425^{\prime}$ to sidetrack crescent wrench. Blew hole with air and bailed. Circulated out $4^{\prime}$ of formation to $429^{\prime}$ and cut core 15 from $429^{\prime}$ to $448^{\prime}$, recovered $15-1 / 2^{\prime}$. Reamed core hole to $448^{\prime}$ with $12-1 / 4^{\prime \prime}$ bit. Blew hole with air and bailed. Circulated out $I^{\prime}$ of formation to $449^{\prime}$ and cut core 非 16 from $449^{\prime}$ to $469^{\prime}$, recovered $15.7^{\prime}$. Reamed core hole to $469^{\prime}$ with 12-1/4" bit. Blew hole with air and bailed. Cut core 非17 from $469^{\prime}$ to $495^{\prime}$, recovered $15.3^{\prime}$. Reamed core hole to $495^{\prime}$ with 12-1/4" b1t. Blew hole with air and bailed. Cut core \#18 from $495^{\prime}$ to $508^{\prime}$, recovered $13^{\prime}$. Reamed and drilled using conventionai circulation with ais foam. Cored with rubber sleeve core barrel, 7-1/2" core bit, circulated with air.

Reamed core hole to $508^{\prime}$ with 12-1/4" bit. Blew hole with air and bailed. Circulated out $2^{\prime}$ of formation to $510^{\prime}$ and cut core 非 19 from $510^{\prime}$ to $530^{\prime}$, recovered $14-14^{\prime}$. Reamed core hole to $530^{\prime}$ with 12-1/4" bit. Blew hole with air and bailed. Cut core 非 20 from $530^{\prime}$ to $550^{\prime}$, recovered $17^{\prime}$. Reamed core hole to $550^{\prime}$ with 12-1/4" bit. Blew hole with air and bailed. Clrculated out $5^{\prime}$ of formation to $555^{\prime}$ and cut core 非 21 from $555^{\prime}$ to $573^{\prime}$. Reamed using conventional circulation with air-foam. Cored with rubber sleeve core barrel, $7-1 / 2^{\prime \prime}$ core bit, circulated with air.

3-29-73 Pulled core 非1, recovered 12'. Reamed core hole to $573^{\prime}$ with 12-1/4' b1t. Blew hole with air and bailed. Circillated out ' $'$ ' of formation to $575^{\prime}$ and cut core $\left.\right|^{\prime 2} 2$ from $575^{\prime}$ to $595^{\prime}$, recovered $6^{\prime}$. Cleaned out fill from $567^{\prime}$ and reamed core hole to $595^{\prime}$ with $12-1 / 4^{\prime \prime}$ bit. Blew hole with air and bailed. Cut core $\left.\right|^{2} 23$ from $595^{\prime}$ to $615^{\prime}$, recovered 20'. Reamed core hole to $615^{\prime}$ with 12-1/4" bit. Blew hole with air and bailed. Circulated out $5^{\prime}$ of formation to $620^{\prime}$ and cut core 非 24 from $620^{\prime}$ to $640^{\prime}$, recovered $18^{\prime}$. Reamed using conventional circulation with air foam. Cored with rubber sleeve core barrel, 7-1/2" core bit, circulated with air. 
Reamed core hole to $640^{\prime}$ with 12-1/4" bit. Blew hole with air and bailed. Circulated out $2^{\prime}$ of formation to $642^{\prime}$ and cut core $\$ 25$ from $642^{\prime}$ to $662^{\prime}$, recovered $18-1 / 2^{\prime}$. Reamed core hoie to $662^{\prime}$ with $12-1 / 4^{\prime \prime}$ bit. Blew hole with air. Ran Birdwell caliper log to $661^{\prime}$. Bailed hole. Cut core 非26 from 662' to $682^{\prime}$, recovered 18-1/4'. Reamed core hole to $682^{\prime}$ with 12-1/4' bit. Blew hole with air and bailed. Circulated out $3^{\prime}$ of formation to $685^{\prime}$ and cut core 非 27 from $685^{\prime}$ to $705^{\prime}$, recovered $18^{\prime}$. Reamed core hole to $705^{\prime}$ with 12-1/4" bit. Reamed using conventional circulation with air-foam. Cored with rubber sleeve core barrel, 7-1/2" core bit, circulated with air.

3-31-73 Blew hole with air and bailed. Circulated out 2 ' of formation to $707^{\prime}$ and cut core 非 28 from $707^{\prime}$ to $727^{\prime}$, recovered 19-1/2'. Reamed core hole to $727^{\prime}$ with $12-1 / 4^{\prime \prime}$ bit. Blew hole with air and bailed. Cut core $\$ 29$ from $727^{\prime}$ to $747^{\prime}$, recovered 18-1/2". Reamed core hole to $747^{\prime}$ with 12-1/4" bit. Circulated out $2^{\prime}$ of formation to $749^{\prime}$

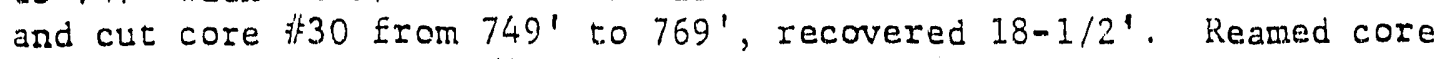
hole to $769^{\prime}$ with 12-1/4" bit. Reamed using conventional circulation with air foam. Cored with rubber sleeve core barrel, $7-1 / 2 "$ core bit, circulated with air.

Blew hole with air and bailed. Cut core 非 31 from $769^{\prime}$ to $790^{\prime}$, recovered 19.3'. Reamed core hole to $790^{\prime}$ with 12-1/4" bit. Blew hole with air and bailed. Cut core 非 32 from $790^{\prime}$ to $810^{\prime}$, recovered 19'. Reamed core hole to 810' with 12-1/4" bit. Blew hole with air and bailed. Circulated out $2^{\prime}$ of formation to $812^{\prime}$ and cut core 非3 from $812^{\prime}$ to $832^{\prime}$, recovered $17.5^{\prime}$. Reamed core hole to $832^{\prime}$ with 12-1/4" bit. Reamed using conventional circulation with air foam. Cored with rubber sleeve core barrel, 7-1/2" core bit, circulated with air.

4-2-73 Blew hole with air and bailed. Cut core 非 34 from 832' to $852^{\prime}$, recovered $17^{\prime}$. Reamed core hole to $852^{\prime}$ with $12-1 / 4^{\prime \prime}$ bit. Blew hole with air and bailed. Cut core 非 35 from $852^{\prime}$ to $872^{\prime}$, recovered $16.5^{\prime}$. Reamed core hole to $872^{\prime}$ with 12-1/4' bit. Blew hole with air and bailed. Cut core 非 36 from $872^{\prime}$ to $892^{\prime}$, recovered $16.7^{\prime}$. Reamed core hole to $892^{\prime}$ with 12-1/4" bit. Reamed using conventional circulation with air foam. Cored with rubber sleeve core barrel, $7 m 1 / 2 "$ core bit, circulated with air.

Blew hole with air and bailed. Cut core "̈37 from 892' to $910^{\prime}$, recovered 15'. Reamed core hole to $910^{\prime}$ with 12-1/4" bit. Blew hole with air and bailed. Cut core $\# 38$ from $910^{\prime}$ to $930^{\prime}$, recovered 18'. Reamed core hole with 12-1/4" bit to 930'. Blew hole with air and bailed. Cut core $\equiv_{3} 39$ from $930^{\prime}$ to 950', recovered 16'. Reamed core hole to $950^{\prime}$ with 12-1/4' bit. Pulled out of hole and secured rig at 2400 hours. Reamed using conventional circulation with air foam. Cored with rubber sleeve core barrel, 7-1/2" core bit, circulated with air. 
UEm $6 e$

Hole History

Page 4

$4-4-73$

Rig secured to 0900 hours. Blew hole with air and bailed. Cut core

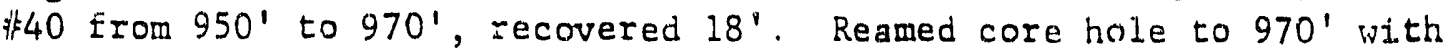
12-1/4" bit. Circulated out 2' of formation to $972^{\prime}$ and cut core 非 41 from $972^{\prime}$ to $992^{\prime}$, recovered $17^{\prime}$. Reamed core hole to $992^{\prime}$ with 12-1/4" bit. Blew hole with air. Secured rig at 2400 hours.

Rig secured to 0900 hours. Bailed hole. Cut core $k^{4} 42$ from 992 to $1012^{\prime}$, recovered 17'. Reamed core hole to $1012^{\prime}$ with 12-1/4' bit. Blew hole with air and bailed. Cut core 743 from 1012' to 1032', recovered 15-1/2'. Reamed core hole to $1032^{\prime}$ with 12-1/4' bit. Reamed using conventional circulation with air-ioam. Cored with rubber sleeve core barrel, 7-1/2" core bit, circulated with air.

Blew hole with air and bailed. Cut core 非4 from 1032' to $1052^{\prime}$, recovered 17.1'. Reamed core hole to $1052^{\prime}$ with 12-1/4" bit. Blew hole with air and bailed. Cut core 非 45 from 1052' to 1071', recovered 16'. Reamed core hole to 1071' with 12-1/4" bit. Cut core 非46 from 1071' to 1091', recovered 16.2'. Reamed core hole to $1091^{\prime}$ with 12-1/4" bit. Reamed using conventional circulation with air foam. Cored with rubber sleeve core barrel, 7-1/2" core head, circulated with air.

$4-7-73$

Blew hole with air and bailed. Cut core 非 4 from 1091' to 1111', recovered $11^{\prime}$. Reamed core hole to 111!' with 12-1/4" bit. Cut core 非8 from $1111^{\prime}$ to $1131^{\prime}$, recovered $15^{\prime}$. Reamed core hole to 1131 ' with 12-1/4" bit. Blew hole with air and bailed. Circulated out $4^{\prime}$ of formation to $1135^{\prime}$ and cut core k $^{\prime} 9$ from $1135^{\prime}$ to $1155^{\prime}$, recovered 13'-7". Reamed core hole to $1155^{\prime}$ with 12-1/4" bit. Reamed using conventional circulation using air foam. Cored with rubber sleeve core barrel, 7-1/2" core bit, circulated with air.

$4-8-73$

Blew hole with air and bailed. Cut core 非 50 from $1155^{\prime}$ to $1167^{\prime}$, recovered 9'. Reamed core hole and drilled 12-1/4" hole from 1167' to $1174^{\prime}$. Blew hole with air and bailed. Cut core 非 1 from $1174^{\prime}$ to $1194^{\prime}$, recovered 12'. Reamed core hole to $1194^{\prime}$ with 12-1/4" bit. Blew hole with air and bailed. Cut core 非2 from $1194^{\prime}$ to $1214^{\prime}$, recovered 13-1/2'. Reamed core hole to $1214^{\prime}$ with $12-1 / 4^{\prime \prime}$ bit. Reamed using conventional circulation with air foam. Cored with rubber sleeve core barrel, $7-1 / 2 "$ core bit, circulated with air.

4-9-73 Blew hole with air and bailed. Cut core 非53 from $1214^{\prime}$ to $1234^{\prime}$, recovered 1'. Reamed core hole to $1234^{\prime}$ with 12-1/4" bit. Blew hole with air and bailed. Circulated out $10^{\prime}$ of formation to $1244^{\prime}$ and cut core 非 4 from $1244^{\prime}$ to $1255^{\prime}$, recovered 5'. Reamed core hole to $1255^{\prime}$ with 12-1/4" bit. Blew hole with air and bailed. Cut core 非5 from $1255^{\prime}$ to $1267^{\prime}$, recovered $1 / 2^{\prime}$. Reamed using conventional circulation with air foam. Cored with rubber sleeve core barrel, $7-1 / 2 "$ core bit, circulated with air. 
Reamed core hole to $1267^{\prime}$ with 12-1/4" b1t. Blew hole with air and balled. Cut core $k^{56}$ from $1267^{\prime}$ to $1287^{\prime}$, recovered $12^{\prime}$. Reamed core hole 1287' with 12-1/4" bit. Blew hole with air and bailed. Cut core 157 from $1287^{\prime}$ to $1307^{\prime}$, recovered 18'. Reamed core hole to $1307^{\prime}$ with 12-1/4" bit. Blew hole with ais and bailed. Cut core it58 from $1307^{\prime}$ to $1327^{\prime}$, recovered $14^{\prime}$. Reamed core hole to $1327^{\prime}$ with 12-1/4" b1t. Reamed using conventional circulation with air foam. Cored with rubber sleeve core barrel, $7-1 / 2^{\prime \prime}$ core bit, c1rculated with air.

Blew hole with air and balled. Cut core $k^{5} 59$ from $1327^{\prime}$ to $1347^{\prime}$, recovered $14^{\prime}$. Reamed core hole to $1347^{\prime}$ with 12-1/4" bit. Blew hole with air and bailed. Circulated out $3^{\prime}$ of formation to $1350^{\prime}$ and cut core $\$ 100$ from $1350^{\prime}$ to $1370^{\prime}$, recovered 11.2'. Reamed core hole to $1370^{\prime}$ with 12-1/4" b1t. Blew hole with ais and bailed. Cut core $\equiv^{6} 61$ from $1370^{\prime}$ to $1390^{\prime}$, recovered $5^{\prime}$. Reamed using conventional circulation with air foam. Cored with rubber sleeve core barre1, 7-1/2" core bit, circulated with a1r.

Reamed core hole and drilled 12-1/4" hole from 1390' to 1460'. Cut

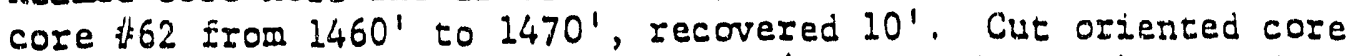
非 63 from $1470^{\prime}$ to $1478^{\prime}$, recovered $8^{\prime}$. Reamed core hole and drilled 12-1/4' hole from 1478' to 1493'. Reamed and drilled using conventIonal circulation with air Eoam. Cored with conventional core barrel 8-11/16" core bit, circulated with air foam.

Drilled 12-1/4" hole from 1493' to 1625'. Secured rig at 1200 hours. (Drilled $132^{\prime}$ in 8 rotating hours, $100 / 110 \mathrm{xpx}, 3 / 500$ 非 wt. on bit, 90 psi, conventional circulation using alr foam.)

4-14-73 RIg secured.

4-15-73 Rig secured.

$4-16-73$

$4-17-73$

$4-21-73$

Rig secured to 0800 hours. Ran Birdwell fluid density, caliper, density and epithermal neutron logs to $1624^{\prime}$, fluid level at $1520^{\prime}$.

Completed runaing Birdwell epithemal neutron log. Rig secured at 0500 hours.

Rig secured from 4-17-73 to 0900 hours on 4-21-73. Ran Birdwell fluid denstty $\log$ to $1624^{\prime}$, fluid level at $1520^{\prime}$. Ran Sperry-Sun mitishot survey in and out of the hole on $30^{\prime}$ stations. Took Hunt sidewall samples at $10^{\prime}$ intervals Erom $1450^{\prime}$ to $1400^{\prime}$, at $1370^{\prime}$, $1365^{\prime}, 1330^{\prime}, 1325^{\prime}, 1270^{\prime}, 1265^{\prime}, 1260^{\prime}$ and $1245^{\prime}$.

$4-22-73$

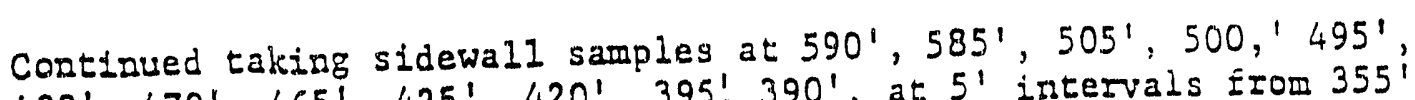
$490^{\prime}, 470^{\prime}, 465^{\prime}, 425^{\prime}, 420^{\prime}, 395^{\prime}, 390^{\prime}$, at $5^{\prime}$ intervals Erom $355^{\prime}$, to $315^{\prime}$, and $290^{\prime}$ to $265^{\prime}$, at $225^{\prime}, 205^{\prime}, 200^{\prime}, 165^{\prime}, 145^{\prime}, 130^{\prime}$, and $125^{\prime}$. Drilled $12-1 / 4^{\prime \prime}$ hole Erom $1625^{\prime}$ to $1748^{\prime}$ using conventiopel circulation with air foam. Cut oriented core $k^{64}$ from $1748^{\prime}$ to $1762^{\prime}$, recovered 14'. Cored with conventional core barrel, 8$11 / 16^{\prime \prime}$ core b1t, c1rculated with air ioam. 
Reamed core hole to $1762^{\prime}$ and drilled 12-1/4' hole from $1762^{\prime}$ to $1885^{\prime}$. Cut oriented core 非 65 from $1885^{\prime}$ to $1895^{\prime}$, recovered $5^{\prime}$. Cored with conventional core barrel, 8-11/16" core bit. Drilled and cored using conventional circulation with air foam.

Reamed core hole to $1895^{\prime}$ and drilled $12-1 / 4^{\prime \prime}$ hole from $1895^{\prime}$ to $1977^{\prime}$. Secured rig at 2400 hours.

Rig secured from 4-24-73 to 1800 hours on 5-4-73. Rigged up for dual string drilling.

5-5-73 Rigged up for dual string drilling with air and water. Tagged fill at 1940'. Cleaned out fill from $1940^{\prime}$ to $1950^{\prime}$.

$5-6-73$

Cleaned out fill from $1950^{\prime}$ to $1977^{\prime}$ and drilled 12-1/4" hole from $1977^{\prime}$ to $2050^{\prime}$ using dual string reverse circulation with air and water. Ran Birdwell fluid density log to 2005', fluid level at 1592'. Cut core 非66 from 2050' to 2060', recovered $2^{\prime}$. Cored with conventional core barrel, 8-11/16" core bit, circulated with water.

5-7-73 Reamed core hole and drilled 12-1/4' hole from 2060' to 2086'. Hole stopped unloading. Pulled out of hole to check inner string.

Repaired leaks in dual string drillpipe and cleaned out fill from $2020^{\prime}$ to $2040^{\prime}$ using air and water. Secured rig at 2400 hours.

Rig secured to 0800 hours. Tagged fill at 2010'. Cleaned out fill from 2010' to 2086'. Drilled 12-1/4' hole from 2086' to $2129^{\prime}$. (Drilled $43^{\prime}$ in 8 rotating hours, $40 \mathrm{rpm}, 15,000$ 非 wt. on bit, 400 psi, dual string drilling with reverse circulation using air and water.)

Drilled 12-1/4" hole from 2129' to 2202'. Cleaned out fill from $2040^{\prime}$ to $2138^{\prime}$ after trip. (Drilled $73^{\prime}$ in $14-1 / 2$ rotating hours, $40 / 50 \mathrm{Ipm}, 15,000$ 非 wt. on bit, $400 \mathrm{psi}$, dual string drilling with reverse circulation using air and water.)

$5-11-73$

Drilled 12-1/4" hole from 2202' to $2295^{\prime}$. Pumped 280 barrels of mud in the hole. Pulled out of hole. Ran B1rdwell. fluid density $10 g$ and depth check. Tagged bottom at 2293', fluid level at 1169'. Ran core barrel in the hole. (Drilled $93^{\prime}$ in $12-1 / 2$ rotating hours; $50 \mathrm{rpm}, 10 / 15,000$ 非 wt. on bit, $375 \mathrm{psi}$, dual string drilling with reverse circulation using air and water.)

5-12-73 Cut core 非 67 from $2295^{\prime}$ to $2297^{\prime}$, recovered 1'. Left matrix off of core bit in hole. Ran Birdwell fluid density and caliper logs to 2294', fluid leve1 at $961^{\prime}$. Ran 11-1/4" O.D. Globe basket jin the hole, could not get below $2145^{\prime}$. Ran $12-1 / 4^{\prime \prime}$ bit in the hole and drilled on junk from $2297^{\prime}$ to $2302^{\prime}$.

5-13-73 Dr1lled 22-1/4" hole from 2302' to $2428^{\prime}$. No sign of junk. (Dri11-

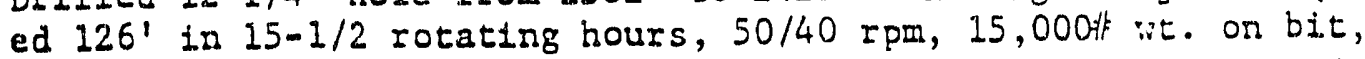
400 psi, dual string drilling with reverse circulation using air and water.) 
Drilled 12-1/4" hole from 2428' to $2458^{\prime}$. Pumped in 250 barrels of mud and pulled out of hole. Secured rig at 0800 hours. (Drilled $30^{\prime}$ in 4 rotating hours, $35 \mathrm{rpm}, 15,000$ 非 wt. on bit, $400 \mathrm{psi}$, dual string drilling with reverse circulation using air and water.)

$5-15-73$

$5-16-73$

Rig secured to 1030 hours. Unload hole. Drilled 12-1/4" hole from $2458^{\prime}$ to $2499^{\prime}$. (Drilled $41^{\prime}$ in 4 rotating hours, $40 \mathrm{rpm}, 15,000$ 非 wt. on bit, 400 psi, dual string drilling with reverse circulation using air and water.)

Drilled 12-1/4" hole from $2499^{\prime}$ to $2728^{\prime}$. Pulled out of hole to check for leaks in inner string. Checked fluid level at $2130^{\prime}$ on connection at $2510^{\prime}$ and at $1970 !^{\prime}$ on connection at $2634^{\prime}$. Ran Birdwell water locator on connection at $2696^{\prime}$, fluid level at $1544^{\prime}$. (Drilled $229^{\prime}$ in $18-1 / 2$ rotating hours, $35 / 40 \mathrm{rpm}, 10 / 15,000$ 非 wt. on bit, $450 / 525$ psi, dual string drilling with reverse circulation using air and water.)

5-17-73 Checked drill pipe for leaks. Cleaned out $12^{\prime}$ of fill and drilled 12-1/4" hole from $2728^{\prime}$ to $2796^{\prime}$. (Drilled 68' in 5-1/2 rotating hours, $40 \mathrm{rpm}, 15,000$ 非 wt. on bit, $525 \mathrm{psi}$, dual string drilling with reverse circulation using air and water.)

5-18-73 Drilled 12-1/4' hole from 2796' to $2885^{\prime}$. Made trip for new bit and could not break circulation. Pulled out of hole to check inner string

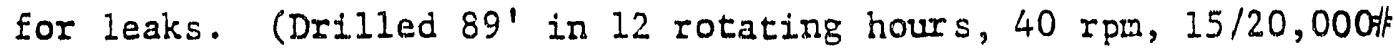
wt. on bit, $525 / 500$ psi, dual string drilling with reverse circulation using air and water.)

5-19-73 Pulled out of hole checking inner string for leaks. Ran Birdwell water locator, fluid level at 1511'. Ran back in hole. Ran water locator, fluid level at $1476^{\prime}$. Could not get hole to unload. Made trip to check for leaks. Cleaned out $20^{\prime}$ of fill to $2843^{\prime}$ and could not get hole to unload.

5-20-73 Checked drill pipe for leaks. Ran 12-1/4" bit in the hole and cleaned out fill from 2808' to $2824^{\prime}$.

5-21-73 Cleaned out fill from 2824' to $2885^{\prime}$. Pumped 280 barrels of mud in the hole. Ran Birdwell caliper $\log$ to $1881^{\prime}$. Ran fluid density log, fluid level at $1215^{\circ}$. Ran vibroseis survey.

5-22-73 Completed running vibroseis survey. Pumped 520 barrels of mud in the hole. Monitored fluid level with Birdwell fluid density log, top of fluid at $16^{\prime}$. Fluid level dropped $22^{\prime}$ in 15 minures. Ran electric and 3-D logs to 2825'. Pumped in 175 barrels of and keeping hole full whill logging.

5-23-73 Completed running Birdwell 3-D $\log$ to 2825'. Ran density tool to bridge at $2196^{\prime}$, worked tool to $2112^{\prime}$ and could not move. Pulled wire line out of the hole and started fishing for density tool. Secured rig at 2400 hours. 


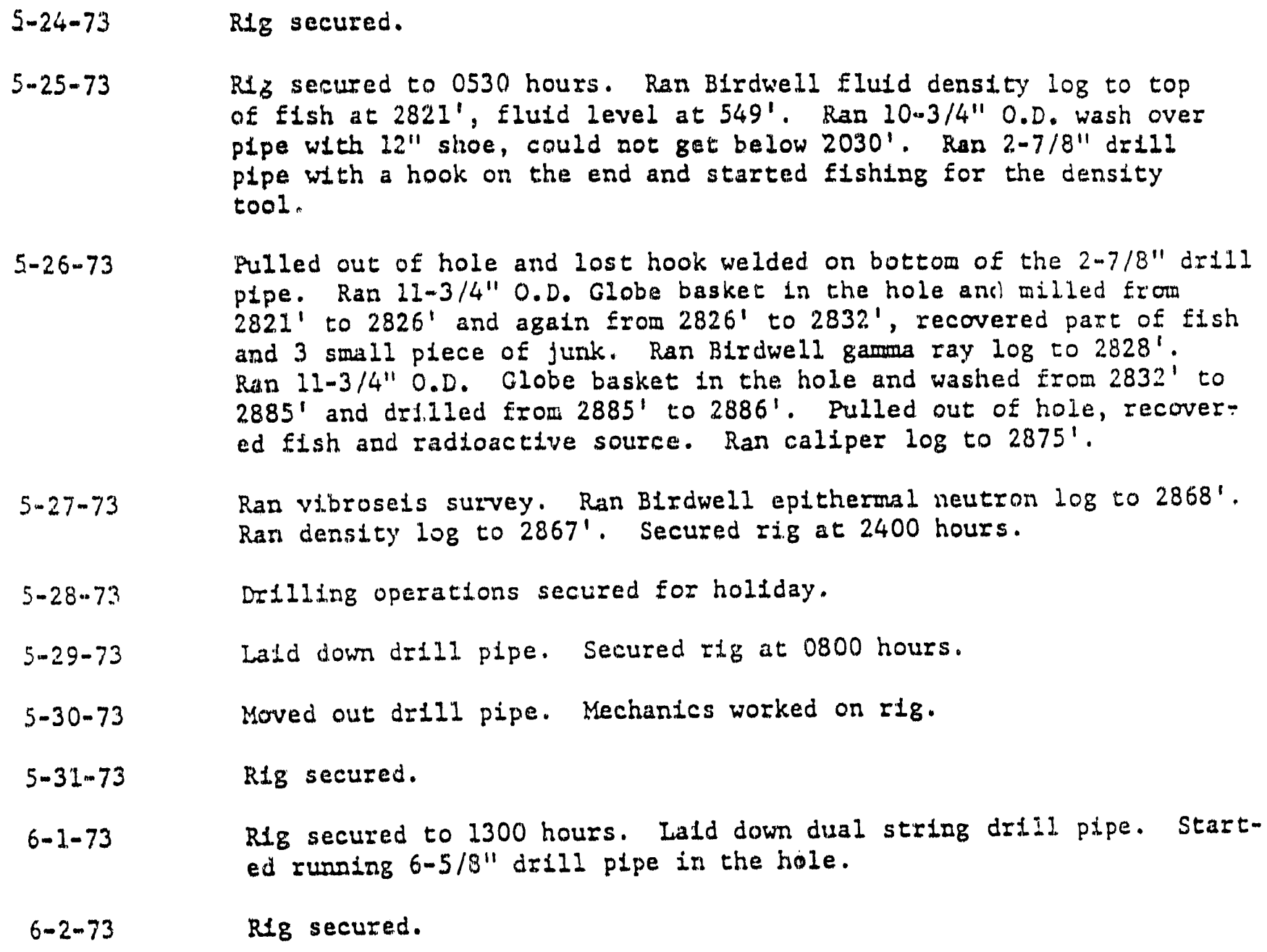

5-26-73 Pulled out of hole and lost hook welded on bottom of the $2-7 / 8^{\prime \prime}$ dril1 pipe. Ran 1I-3/4" O.D. Globe basket in the hole ancl milled from $2821^{\prime}$ to $2826^{\prime}$ and again from $2826^{\prime}$ to $2832^{\prime}$, recovered part of Eish and 3 small piece of junk. Ran Birdwell gama ray $10 g$ to $2828^{\prime}$. Ran 11-3/4" O.D. Globe basket in the hole and washed From $2832^{\prime}$ to $2885^{\prime}$ and drliled from $2885^{\prime}$ to $2886^{\prime}$. Pulled out of hole, recover: ed fish and radioactive source. Ran caliper log to $2875^{\prime}$.

Monttored cementing with the DCTI $10 \mathrm{~g}$ and fluld levels with the Iluid deasity log. Stage 12 and 13 were cement down the annulus starting at the metal petal basket. RIg secured at 2200 hours.

R1g secured to 1200 hours. Completed rigging down. Hole suspended. ped to $45 \%$ Cemented anaulus to surface with $85 \mathrm{ft}^{3}$ of neat cement. CIP at 1830 hours. Hole suspended. 
9-17-73 Hole suspended from 6-15-73 to 9-17-73. Moved in Ideco 525 Iig and began rigging up.

9-18-73 Completed rigging up and began blowing water from hole.

9-19-73 Drilled out cement and shoe from 2085' to 2090'. Cleaned out E111 from 2090' to $2886^{\prime}$. Drilled 8-3/4' hole from $2886^{\prime}$ to $2968^{\prime}$ using conventional circulation with atr foam.

9-20-73 Drilled 8-3/4" hole from 2968' to $3175^{\prime}$. had difficulty unloading hole at $3111^{\prime}$.

9-21-73 Drtiled 8-3/4" hole from 3175' to 3501'. Ran Birdwell Eluid density log, stopped at 2349'. Secured Iig at 2400 hours.

9-24-73 Rig secured from 9-21-73 until 0 hours on 9-24-73. Ran Birdwell fluid density log, stopped at 2329'. Top of soapy fluid at $1515^{\prime}$. Laid down 2 crooked $6^{\prime \prime}$ drill collars. Trip in to 2526', could not unload. Pulled up to 2212', unloaded hole and cleaned out f1ll. Pushed through bridges at $2329^{\prime}$ and $2349^{\prime}$. Drilled 8-3/4" hole from $3501^{\prime}$ to $3814^{\prime}$.

9-25-73 Drilled 8-3/4" hole from 3814' to 4113'. Secured rig at 2400 hours.

9-26-73 R1g secured Erom 9-25-73 unt11 0800 hours on 9-26-73. . R1gged down and secured operations at 1600 hours.

10-26-73 Rig secured from 9-26-73 unt11 0001 hours on 10-26-73. Rigged trip in hole to bottom of 9-5/8" casing. Secured rig at 2400 hours.

10-29-73 Rig secured from 10-26-73 unt1 0 hours on 10-29-73. Trip in hole, hit bridge at 3945'. Cleaned out bridge and pumped in 140 bbls. of mud. Finished trip in hole and drilled $8-3 / 4^{\prime \prime}$ hole from $4113^{\prime}$ to 4114'. Cleaned out $35^{\prime}$ of E111 and cut core 168 from $4114^{\prime}$ to $4128^{\prime}$ Cored with conventional core barrel, 8m11/16" core b1t. Drilled and cored using conventional circulation with mud.

10-30-73 Finished trip out of hole with core 1368 , no recovery. Reamed core interval and drilled 8-3/4" to le from 4128' to 4160' with bit and fuak basket, attempting to plck up junk.

10-31-73 Conditioned hole and trip out. Plcked up core barrel and cut core 469 from $4160^{\prime}$ to $4173^{\prime}$, recovered $12^{\prime}$. Cored with conventional core barrel, 8-11/16" bit. Reamed core laterval and drilled 8-3/4" hole from $4160^{\prime}$ to $4191^{\prime}$. Drllled and core using conventional circulation with mud.

11-1-73 Drilled 8-3/4" hole from 4191' to 4209', Conditioned hole and attenpted to run Bdrdwell epithermal neutron log, hit brioge at 2887'. Trip in and drilled our bildges. Conditioned hole and ran epithermal neutron log to $4208^{\circ}$. Began running density log.

11-2-73 Finduhed runn\$ng dengtty log to 4208'. Ran electzis log to $4208^{\prime}$. Ran 3-D 208, tool wauld not work. Atcempted to re-run epithermal neutron log, tool stuek at 2250'. Worked loose and stuck tool at bottom of 9-5/8" casing at 2090'. Worked loose and pulled out of hole, tool leverage ara was disfigured. Ran depen cneck ro $4208^{\prime}$. Secured rig at 2400 hours. 
$U E-6 e$

Hole History

Page 10

11-5-73 Rig secured from 11-2-73 until 0 hours on 11-5-73. Attempted to run temperature log. Worked tool thru bridge at 2730' and plugged tool. Pulled out and cleaned tool. Re-ran temperature $\mathrm{log}$, could not work tool deeper than 3317'. Pulled out and ran in hole with 8-3/4" bit, conditioned hole and trip out. Ran epithermal neutron and 3-D logs to $4207^{\prime}$.

11-6-73 Finished running 3-D logs (2 runs) to 4207'. Attempted to run seisviewer $\log$, no signal. Ran caliper $\log$ to $4208^{\prime}$. Picked up Hunt sidewall sampling tools and began sidewall sampling.

11-7-73 Sidewall sampled on $25^{\prime}$ stations as directed by the User.

11-8-73 Continued sidewall samling as directed by the User.

11-9-73 Completed sidewall sampling. Began rigging down. Secured Iig at 1000 hours.

11-12-73 Rig secured from 11-9-73 until 0800 hours on 11-12-73. Trip in hole and circulated mud from hole. Trip out and secured rig at 1630 hours. Ran Birdwell seisviewer log from 4017' to 2080'. Ran fluid density $\log$ to $550^{\prime}$, fluid level at $524^{\prime}$.

12-2-73 Rig secured from 11-12-73 until 1200 hours on 12-2-73. Trip in hole with 4l'" drill pipe, hit bridge at $3275^{\prime}$. Trip out and began rigging down.

12-3-73 Completed rigging down and moved off. Hole completed.

\section{SPERRY-SUN MILIISHOT SURVEY}

\begin{tabular}{|c|c|c|c|c|c|}
\hline Date & ID & IVD & Horizontal Disoiacement & Reference & $\underline{\text { Run }}$ \\
\hline $\begin{array}{l}4-21-73 \\
4-21-73\end{array}$ & $\begin{array}{r}1619^{\prime} \\
1619^{\prime} \\
9-5 /\end{array}$ & $\begin{array}{l}1618.95^{\prime} \\
1618.95^{\prime}\end{array}$ & $\begin{array}{l}6.46^{\circ}, 533^{\circ} 30^{\prime} \mathrm{W} \\
6.48^{\prime}, 533^{\circ} 57^{\prime} \mathrm{W}\end{array}$ & $\begin{array}{l}587-5 \cup 3-1999 \\
587-5 \cup 3-1999\end{array}$ & $\begin{array}{l}\text { In } \\
\text { Dut }\end{array}$ \\
\hline
\end{tabular}

\begin{tabular}{|c|c|c|c|}
\hline Stage No. & Interval & Cement Used $-F t^{3}$ & $\begin{array}{l}\text { Calc. Annular } \\
\text { Yolume - Ft }\end{array}$ \\
\hline $\begin{array}{l}1 \\
2 \\
3 \\
4\end{array}$ & $\begin{array}{r}2090^{\prime}-1722^{\prime} \\
102^{\prime}-93^{\prime} \\
93^{\prime}-58^{\prime} \\
58^{\prime}-\quad 0^{\prime}\end{array}$ & $\begin{array}{r}400 \\
10 \\
150 \\
85 \\
\end{array}$ & $\begin{array}{r}189 \\
11 \\
97 \\
49 \\
\end{array}$ \\
\hline & TOTALL & 645 & 346 \\
\hline
\end{tabular}




\section{UE- $6 e$ \\ REVIEW OF HOLE CONDITIONS}

914 (36") hole was drilled to $36.6 m$ (120') with an auger rig. 508m (20") casing was set at $33.5 \mathrm{~m}\left(110^{\prime}\right)$ and the annulius filled to surface with $21.52 \mathrm{~m}^{3}\left(760 \mathrm{ft}^{3}\right)$ of cement slurry in 3 stages. The calculated annular volume was $17.61 \mathrm{~m}^{3}\left(622 \mathrm{ft}^{3}\right)$.

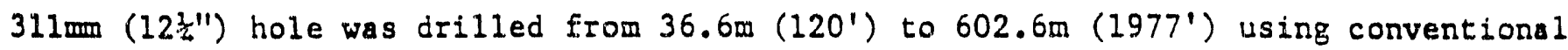
circulation with air foam and with dual string reverse method of circulation using air and water from $602.6 \mathrm{~m}$ (1977') to 879.7m (2886'). The caliper log ran on 5-26-73 indicated hole enlargement from $35.4 \mathrm{~m}$ (116') to $571.2 \mathrm{~m}$ (1874') to maximum diamerers of $660 \mathrm{~mm}\left(20^{\prime \prime}\right)$ at $63.7 \mathrm{~m}\left(209^{\prime}\right)$ and at $192.3 \mathrm{~m}\left(631^{\prime}\right)$. 244mm $\left(9-5 / 8^{\prime \prime}\right)$ casing was set at $637.0 \mathrm{~m}$ (2090') with a formation packer on bottom. The annulus was cemented from the packer to $524.9 \mathrm{~m}\left(1722^{\prime}\right)$ and from a metal petal basket at $31.1 \mathrm{~m}$ (102') to surface with $18.26 \mathrm{~m}^{3}\left(645 \mathrm{ft}^{3}\right)$ of cement slurry in 4 stages. The calculated annular volume for these intervals was $9.80 \mathrm{~m}^{3}$ (346 $\left.\mathrm{ft} \mathrm{t}^{3}\right)$. Fill was cleaned out from $637.0 \mathrm{~m}\left(2090^{\circ}\right)$ to $879.7 \mathrm{~m}\left(2886^{\prime}\right)$ and $222 \mathrm{~mm}\left(8-3 / 4^{\prime \prime}\right)$ hole drilled to $1253.6 \mathrm{~m}$ (4113') using conventional circulation with air foam and to a total depth of $1282.9 \mathrm{~m}$ (4209') using mud. The caliper log ran on 11-6-73 indicated several enlarged intervals to beyond the caliper arm limits of $635 \mathrm{~mm}$ (25') from $703.5 \mathrm{~m}$ (2308') to $736.4 \mathrm{~m}$ (2416') and from $873.6 \mathrm{~m}\left(2866^{\prime}\right)$ to $874.8 \mathrm{~m}\left(2870^{\prime}\right)$ to a diameter of $635 \mathrm{~mm}$ (25"). $61 \mathrm{dry}$ hole cores

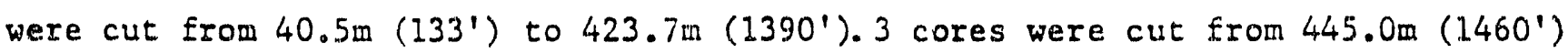

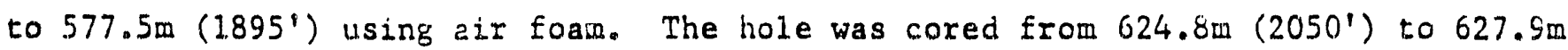

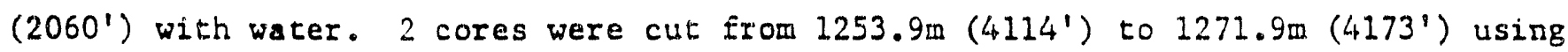
mud. Sidewall samples were taken from 38.1m (125') to 1281.7m (4205'). Caliper, NCTL, density, water locator, fluid density, electric, gamma, epithermal neutron, seisviewer and 3-D logs were run. A vibzoseis survey was run. Fluid density log ran on 11-12-73 indicated fluid at $159.7 \mathrm{~m}$ (524'). 


\section{APPENDIX E}

\section{Hole History Data for Well HTH-3 (Fenix and Scisson, Nevada)}




\section{FENIX \& SCISSON OF NEVADA HOLE HISTORY DATA}

Approved:
Date:

Hole No.: USGS HTH \#3 (Group II) User: USGS/AEC

Location: NTS

Area: 5

Lype Hole: Hydrologic Test

Surface Coordinates: N 750,189' E 736,937'

County:

Nye

Site Prep. W.0.\#:

None

\begin{tabular}{l|l|l|l|l|l|l} 
Ground Elevation: $3477.2^{\prime}$ & Pad Elevation: N/A & Top Casing Elevation: N/A
\end{tabular}

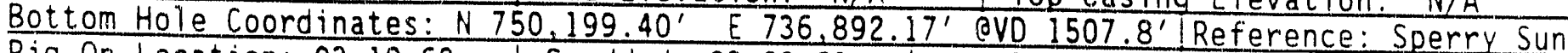

Rig On Location: 03-19-62 L Spudded: 03-22-62 L Completed: 05-11-62

Circulating Media: Conventional, air, mud, air foam

Main Rig \& Contractor: Rig \#22 - Western Republic Orilling Co.

No. Of Compressors \& Capacity: N/A

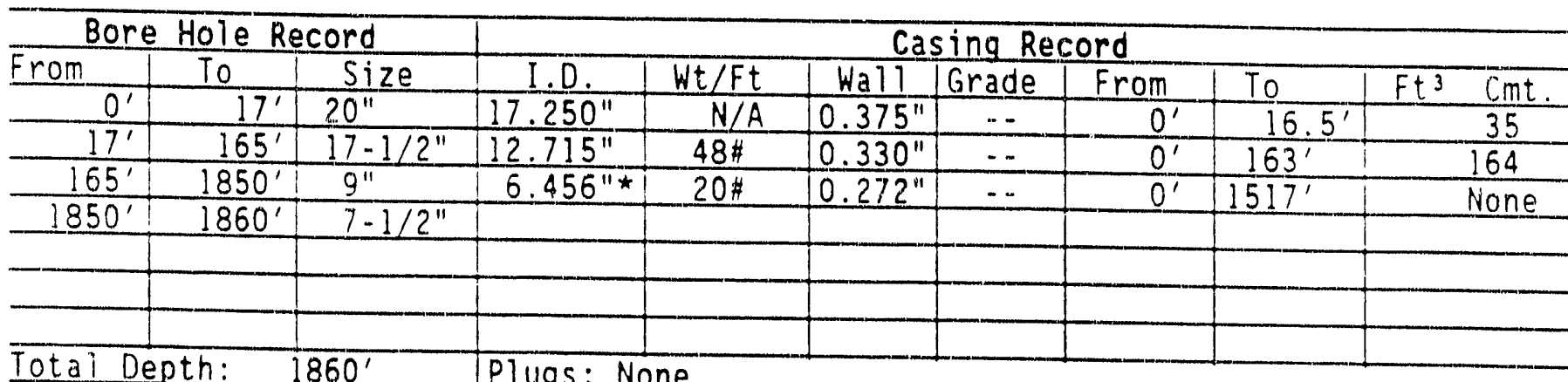

Junk: None

Logging Data: Lane Wells: Electric, Gamma ray-neutron, Induction, Temperature, Sonic, Caliper, Density, Focus

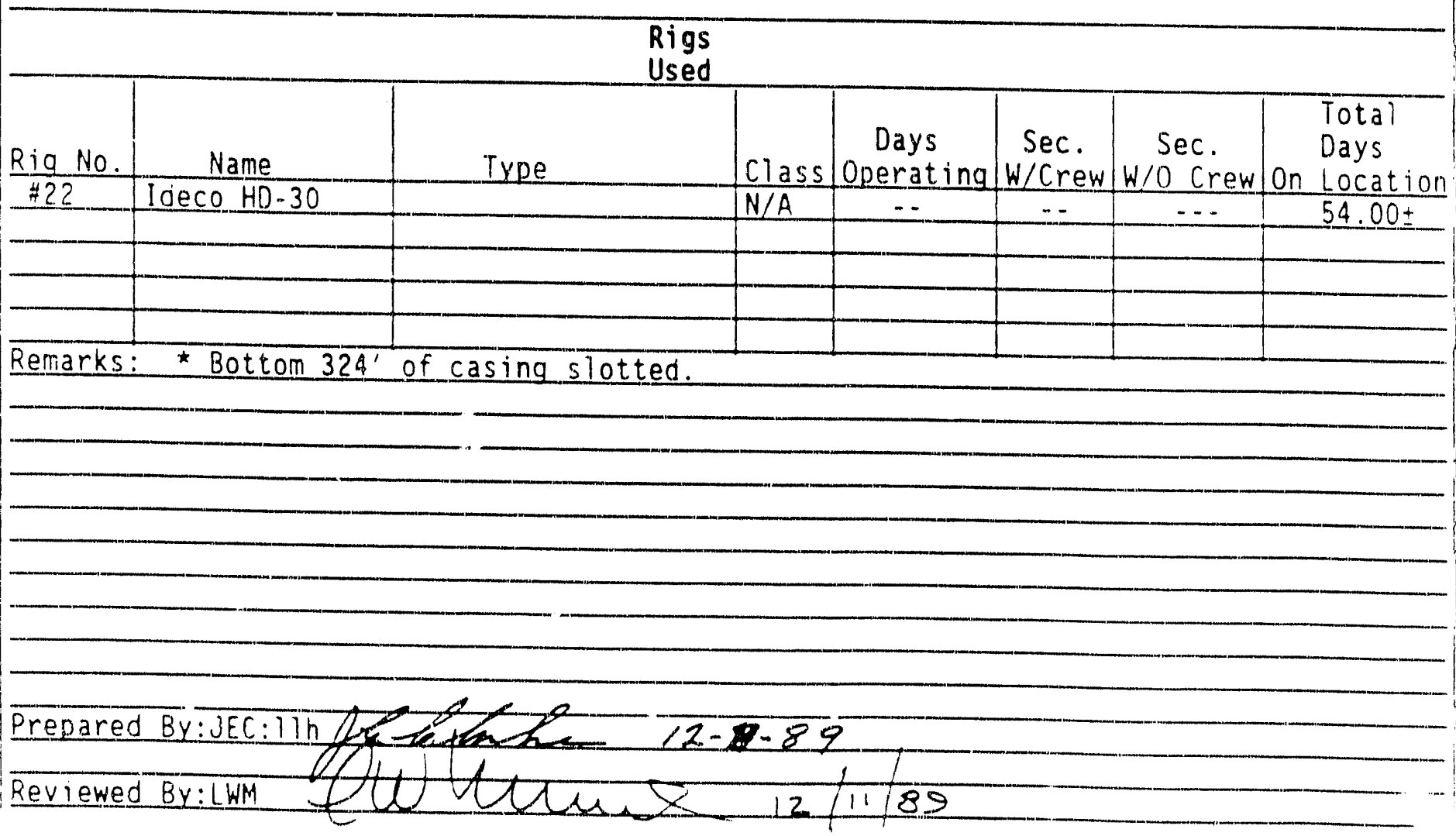




\section{USGS/AEC \\ USGS HTH 3 \\ Group II, Area 5 \\ Hole History}

03-19-62 Moved in Western Republic Orlg. Co. \#22, Ideco HD-30 rig and started rigging up.

03-20-62 Continued rigging up.

03-21-62 Continued rigging up.

03-22-62 Rigged up. Drilled 20" hole from $0^{\prime}$ to $17^{\prime}$. Set $18^{\prime \prime}$ casing at $16.5^{\prime}$ and cemented annulus with $35 \mathrm{ft}^{3}$ of cement.

03-23-62 Waited on tools and made up surface installations.

03-24-62 Rigged up mud equipment. Drilled cement from 16' to $17^{\prime}$ and $7^{\prime \prime}$ nole to $70^{\prime}$ with conventional circulation using mud.

03-25-62 Completed mud equipment installation. Drilled 9" hole from 70' to $72^{\prime}$.

03-26-62 Orilled 9" hole from 72' to 90'. Opened hole to $12-1 / 4^{\prime \prime}$ to $90^{\prime}$ and drilled 12-1/4" hole to $100^{\prime}$.

03-27-62 Drilled 12-1/4" hole from $100^{\prime}$ to $165^{\prime}$ and opened hole to $17-1 / 2^{\prime \prime}$ to $165^{\prime}$ : Set 13-3/8" casing with shoe at $163^{\prime}$. Dev. survey $0100^{\prime}=$ $0^{\circ} 25^{\prime}$.

03-28-62 Cemented the annulus with $165 \mathrm{ft}^{3}$ of common cement $+2 \%$ HA5. CIP at 0200 hours. Drilled cement and shoe to $165^{\prime}$ and $12-1 / 4^{\prime \prime}$ hole to $168^{\prime}$. Blew hole dry.

03-29-62 Cored \#1 and \#2 8-7/8" hole from 168' to $175^{\prime}$ using air, 5.7' recovery.

03-30-62 Opened core hole and drilled $9^{n}$ hole from 175' to 400'. Dev. survey (a) $200^{\prime}=0^{\circ} 30^{\prime}, 300^{\prime}=0^{\circ} 45^{\prime}$, and $393^{\prime}=1^{\circ} 30^{\prime}$.

03-31-62 Drilled 9" hole from 400' to 451'. Cored \#3 8-7/8" hole to 462, $2.2^{\prime}$ recovery. Opened core hole. Dev. Survey $433^{\prime}=1^{\circ} 00^{\prime}$.

04-01-62 Drilled 9" hole from 446' to 600'.

04-02-62 Cored $\# 4$ 8-7/8" hole from 600' to 610', $7^{\prime}$ recovery. Opened core hole and drilled $9^{\prime \prime}$ hole from $610^{\prime}$ to $632^{\prime}$. Cored $\# 58-7 / 8^{\prime \prime}$ hole to $634^{\prime}, 2^{\prime}$ recovery.

04-03-62 Opened core hole and drilled 9" hole from 632' to 701'. Dev. servey (c) $690^{\prime}=1^{\circ} 30^{\prime}$.

04-04-62 Drilled 9" hole f.om 701' to 764'. Dev. survey $746^{\prime}=1^{\prime} 45^{\prime}$.

04-05-62 Orilled 9" hole from 764' to 795'. Cored $\# 68-7 / 8 "$ hole to 805', 5' recovery. Opened core hole.

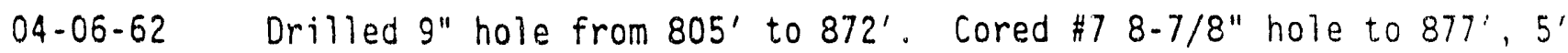
recovery. Opened core hole. Dev. survey o $800^{\prime}=1^{\circ} 4^{\prime \prime} \prime$. 
USGS HTH \#3

Group II, Area 5

Hole History

Page 2

04-07-62 Drilled 9" hole from $877^{\prime}$ to $944^{\prime}$. Dev. survey o $900^{\prime}=2^{\circ} 00^{\prime}$.

04-08-62 Cored \#8 8-7/8" hole to 949', 4.5' recovery. Opened core hole and drilled 9" hole from $949^{\prime}$ to $1050^{\prime}$. Dev. survey $01000^{\prime}=2^{\circ} 30^{\prime}$.

04-09-62 Drilled 9" hole from 1050' to 1127'. Cored \#9 8-7/8" hole to 1132', $3.3^{\prime}$ recovery. Opened core hole and drilled 9" hole from 1132' to $1139^{\prime}$. Dev. survey o $1100^{\prime}=2{ }^{\circ} 45^{\prime}$.

04-10-62 Cored \#10 8-7/8" hole to $1146^{\prime}, 1^{\prime}$ recovery. USGS ran fluid check.

04-11-62 Cored \#11 8-7/8" hole to $1152.5^{\prime}, 4.5^{\prime}$ recovery and \#12. to 1156', $2^{\prime}$ recovery.

04-12-62 Cored \#13 8-7/8" hole to 1158', 1.25' recovery. Opened core hole and drilled 9" hole from 1158' to 1190'.

04-13-62 Orilled 9" hole from 1190' to 1200'. Made trip to bottom with 3-1/2" tubing for swab test, no returns. Ran USGS static fluid level test.

04-14-62 Cored \#14 8-7/8" hole to 1219', 4' recovery. Dropped bolt and nut in hole.

04-15-62 Recovered fish using magnetic basket. Opened core hole and drilled 9" hole to $1225^{\prime}$.

04-16-62 Ran USGS fluid probe, fluid at 1105.8'. Cored \#15 8-7/8" hole to $1234^{\prime}, 7^{\prime}$ recovery and \#16 to 1235', ' ' recovery. Opened core hole and drilled $9 "$ "hole to $1275^{\prime}$.

04-17-62 Drilled 9" hole from 1275' to 1296'. Cored \#17 8-7/8" hole to 1301', $2.5^{\prime}$ recovery. Opened core hole to $9^{\prime \prime}$ to $1301^{\prime}$. Attempted to run swab test using 3-1/2" tubing, lost swab in tubing.

04-18-62 Pulled tubing and recovered swab. Drilled 9" hole from $1301^{\prime}$ to 1322'. Ran 3-1/2" tubing for production test, jetting with air. Recovered 1000 gallons of water in 6 hours.

04-19-62 Completed test. Drilled 9" hole from 1322' to 1340'. Dev. survey (c) $1330^{\prime}=2^{\circ} 45^{\prime}$.

04-20-62 Drilled 9" hole from 1340' to 1358'. Ran swab test with $3-1 / 2^{\prime \prime}$ tubing at $1358^{\prime}$.

04-21-62 Cored \#18 8-7/8" hole to 1363', 3.5' recovery. Opened core hole and drilled 9" hole from $1363^{\prime}$ to $1389^{\prime}$.

04-22-62 Drilled 9" hole from 1389' to 1400'. Ran swab test from $1140^{\prime}$ to $1400^{\prime}$ using $2-7 / 8^{\prime \prime}$ tubing.

04-23-62 Cleaned out 40' fill and drilled 9" hole from 1400' to 1450'. Dev. survey $1420^{\prime}=2^{\circ} 50^{\prime}$. 
USGS HTH \#3

Group II, Area 5

Hole History

Page 3

04-24-62 Cored \#19 8-7/8" hole to $1457^{\prime}, 3^{\prime}$ recovery. Opened core hole and drilled $9^{\prime \prime}$ hole from $1457^{\prime}$ to $1500^{\prime}$.

04-25-62 Ran swab test using 3-1/2" tubing at 1486'. Cored \#20 8-7/8" hole to $1507^{\prime}, 6^{\prime}$ recovery.

04-26-62 Opened core hole and drilled 9" hole from 1507' to 1550'. Dev. survey (o) $1510^{\prime}=2^{\circ} 50^{\prime}$.

04-27-62 Cored \#21 8-7/8" hole to 1555', 2.3' recovery. Opened core hole and drilled $9^{\prime \prime}$ hole from $1555^{\prime}$ to $1595^{\prime}$.

04-28-62 Cored \#22 8-7/8" hole to 1602', 7' recovery. Ran USGS swab test using $3-1 / 2$ " tubing.

04-29-62 Cleaned out 40' fill, opened crre hole, and drilled 9" hole from 1602' to $1650^{\prime}$. Dev. survey o $1600^{\prime}=2^{\circ} 30^{\prime}$.

04-30-62 Cored $\# 23$ 8-7/8" hole to $1657^{\prime}, 7^{\prime}$ recovery. Opened core hole and drilled 9" hole from $1657^{\prime}$ to $1680^{\prime}$.

05-01-62 Drilled 9" hole from 1680' to 1700'. Cored $\# 248-7 / 8 "$ hole to 1707', $7^{\prime}$ recovery. Opened core hole. Dev. survey at $1700^{\prime}=2^{\circ} 30^{\prime}$.

05-02.62 Ran Lane Wells electric log tool, tool stopped at 479'. Drilled 9" hole from 1707' to 1710'.

05-03-62 Ran Lane Wells electric, induction, focus, temperature, gamma ray. neutron, caliper, and density logs. Ran USGS swab tests using Lynes packer on 3-1/2" tubing with packer set at $1614^{\prime}$ then $1459^{\prime}$.

05-04-62 Drilled 9" hole from 1710' to 1745'.

05-05-62 Drilled $9^{n}$ hole from $1745^{\prime}$ to $1780^{\prime}$.

05-06-62 Cored \#25 7-1/2" hole to 1800', 20' recovery. Opened core hole and drilled $9^{\prime \prime}$ hole from $1800^{\prime}$ to $1850^{\prime}$.

05-07-62 Cored \#26 7-1/2" hole to $1860^{\prime}, 7.5^{\prime}$ recovery. Ran swab test with $3-1 / 2^{\prime \prime}$ tubing at $1610^{\prime}$.

05-08-62 Ran Lane Wells gamma ray-neutron, caliper, and electric logs. Ran and 1 anded $7^{\prime \prime}$ O.D., 20\#, J-55 casing with Baker shoe at $1516.64^{\prime}$ and bottom 323.91' of casing slotted. Ran Sperry Sun gyroscopic survey.

05-09-62 Ran and landed Reda pump on 2-7/8" tubing at $1368 /$ along with 1" tubing at $1350^{\prime}$. Started water entry test.

05-10-62 Completed pumping rate test.

05-11-62. Laid down tubing and Reda pump, rig released. Hole completed 05-11-62. 
TABLE E-1. CORED INTERVALS AT HTH - 3 AND RECOVERY.

\begin{tabular}{crc}
\hline Core Number & $\begin{array}{r}\text { Interval } \\
\text { (fect bls })\end{array}$ & $\begin{array}{c}\text { Fect } \\
\text { Recovercd }\end{array}$ \\
\hline 1 and 2 & $168-175$ & 5.7 \\
3 & $451-462$ & 2.2 \\
4 & $600-610$ & 7 \\
5 & $632-634$ & 2 \\
6 & $795-805$ & 5 \\
7 & $872-877$ & 5 \\
8 & $944-949$ & 4.5 \\
9 & $1127-1132$ & 3.3 \\
10 & $1139-1146$ & 1 \\
11 & $1146-1152.5$ & 4.5 \\
12 & $1152.5-1156$ & 2 \\
13 & $1156-1158$ & 1.25 \\
14 & $1200-1219$ & 4 \\
15 & $1225-1234$ & 7 \\
16 & $1234-1235$ & 1 \\
17 & $1296-1301$ & 2.5 \\
18 & $1358-1363$ & 3.5 \\
19 & $1450-1457$ & 3 \\
20 & $1500-1507$ & 6 \\
21 & $1550-1555$ & 2.3 \\
22 & $1595-1602$ & 7 \\
23 & $1650-1657$ & 7 \\
24 & $1700-1707$ & 7 \\
25 & $1780-1800$ & 20 \\
26 & $1850-1860$ & 7.5 \\
\hline
\end{tabular}



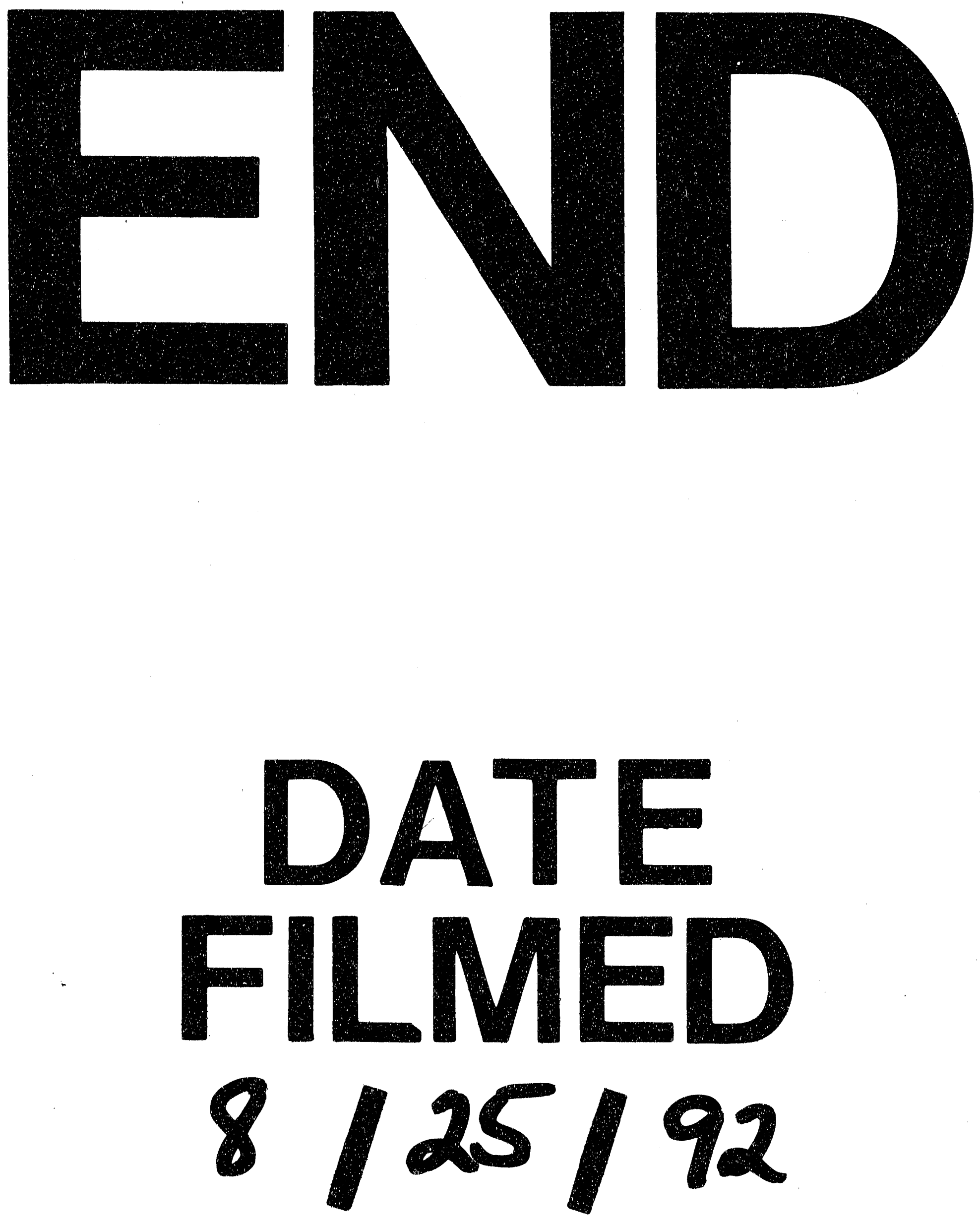

$\exists$ 
: 